\title{
NRC Review of
}

\section{Electric Power Research Institute's}

Advanced Light Water Reactor

Utility Requirements Document

Program Summary

Projeci: Number 669

Manuscript Completed: August 1992

Date Putlished: August 1992

Associate Directorate for Advanced Reactors and License Renewal

Office of Nuclear Reactor Regulation

U.S. Nuclear Regulatory Commission

Washington, DC 20555

This document is 


\section{DISCLAIMER}

This report was prepared as an account of work sponsored by an agency of the United States Government. Neither the United States Government nor any agency Thereof, nor any of their employees, makes any warranty, express or implied, or assumes any legal liability or responsibility for the accuracy, completeness, or usefulness of any information, apparatus, product, or process disclosed, or represents that its use would not infringe privately owned rights. Reference herein to any specific commercial product, process, or service by trade name, trademark, manufacturer, or otherwise does not necessarily constitute or imply its endorsement, recommendation, or favoring by the United States Government or any agency thereof. The views and opinions of authors expressed herein do not necessarily state or reflect those of the United States Government or any agency thereof. 


\section{DISCLAIMER}

Portions of this document may be illegible in electronic image products. Images are produced from the best available original document. 
ABSTRACT

The Electric Power Research Institute (EPRI) is preparing a compendium of technical requirements, referred to as the "Advanced Light Water Reactor [ALNR] Utility Requirements Document," that is applicable to the design of an ALWR power plant. When completed, this document is intended to be a comprehensive statement of utility requirements for the design, construction, and performance of an ALWR power plant for the 1990s and beyond.

The Requirements Document consists of three volumes. Volume I, "ALWR Policy and Summary of Top-Tier Requirements," is a management-level synopsis of the Requirements Document, including the design objectives and philosophy, the ovelall physical configuration and features of a future nuclear plant design, and the steps necessary to take the proposed ALWR design criteria beyond the conceptual design state to a completed, functioning power plant. Volume II con:sists of 13 chapters and contains utility design requirements for an evolutiollary nuclear power plant [approximately 1350 megawatts-electric (MWe)]. Volume III contains utility design requirements for nuclear plants for which passive features will be used in their designs (approximately $600 \mathrm{MWe}$ ).

The staff of the Office of Nuclear Reactor Regulation, U.S. Nuclear Regulatory Comnission, has prepared Volumes 1 and 2 (Parts 1 and 2) of its safety evaluation report (SER) to document the results of its review of Volume $I$ and II cf the Requirements Document. Volume 1, "NRC Review of Electric Power Research Institute's Advanced Light Water Reactor Utility Requirements Document - Program Summary, " provides a discussion of the overall purpose and scope of the Requirements Document, the background of the staff's review, the review approach used by the staff, and a summary of the policy and technical issues raised by the staff during its review. Volume 2, "NRC Review of Electric Power Research Institute's Advanced Light Water Reactor Utility Requirements Document - Evolutionary Plant Designs," gives the results of the staff's review of the 13 chapters of the Requirements Document for evolutionary plant designs. Volume 3, "NRC Review of Electric Power Research Institute's Advanced Light Water Reactor Requirements Document - Passive Plant Designs," scheduled to be issued in September 1993, will give the results of the staff's review of the 13 chapters of the Requirements Document for passive plant designs.

Preliminary drafts of Volumes 1 and 2 were forwarded to the Commission and the Advi iory Committee on Reactor Safeguards (ACRS) on May 12, 1992. In its lettir dated April 24, 1992, the staff issued a draft of Volume 3 on all of the chapters of the Requirements Document for passive plant designs. After the staff has completed its review of EPRI's responses to the draft SER (DSER) on passive plant designs in the form of revisions to the Requirements Document, it will issue a final SER to discuss its conclusions regarding its review of the final version of the document.

In stiaff requirements memoranda (SRM), the Commission instructed the staff to prov de an analysis detailing where the staff proposes departure from current regulations or where the staff is substantially supplementing or revising 
interpretive guidance applied to currently licensed LWRs. The staff considers these to be policy issues. Appendix B to Chapter 1 of Volume 2 of this report gives the staff's regulatory analysis of those issues identified for the evolutionary plant designs. Appendix B to the DSER on Chapter 1 of the Requirements Document for passive plant designs gives the regulatory analysis of those issues identified for the passive plant designs. These issues have been addressed in Commission papers SECY-90-016, "Evolutionary Light Water Reactor Certification Issues and Their Relationship to Current Regulatory Requirements"; SECY-91-078, "Chapter 11 of the Electric Power Research Institute's Requirements Document and Additional Evolutionary Light Water Reactor Certification Issues"; and in draft Commission papers, "Issues Pertaining to Evolutionary and Passive Light Water Reactors and Their Relationship to Current Regulatory Requirements," and "Design Certification and Licensing Policy Issues Pertaining to Passive and Evolutionary Advanced Light Water Reactor Designs," that were issued on February 27 and July 6, 1992, respectively.

In SRM dated June 26, 1990, and April 1, 1991, the Commission provided its decisions on SECY-90-016 and SECY-91-078 as they apply to evolutionary designs. The Commission will be reviewing the basis for the approach that the staff is proposing for those issues discussed in the draft Commission papers of February 27 and July 6, 1992, and, accordingly, may at some future point in the review determine that such issues involve policy questions that the Commission may wish to consider. These issues are considered fundamental to agency decisions on the acceptability of the ALWR designs. The staff will ensure satisfactory implementation of Commission guidance regarding these matters during its review of individual applications for final design approval and design certification.

There are no open issues pertaining to the Requirements Document for evolutionary plant designs other than policy issues on which the staff has taken a position, but for which the Commission has not had the opportunity to provide guidance. In addition, the staff concludes that there are issues that must be satisfactorily resolved before it can complete its review of the Requirements Document for passive plant designs. These issues are summarized in Section 4 of Volume 1 and discussed in detail in this report. 
TABLE OF CONTENTS

Page

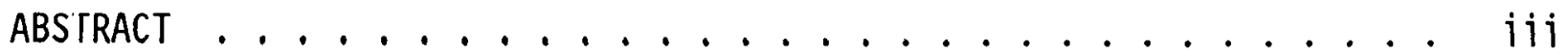

1 INTRODUCTION . . . . . . . . . . . . . . . . . . 1-1

I.1 Background and Review Status ................ . 1-1

1.2 Purpose and Regulatory Status of EPRI's ALWR Utility

Requirements Document .. . . . . . . . . . . . . 1-2

.3 EPRI's Policy Statements . . . . . . . . . . . . . . 1-3

1. 4 ALWR Design Bases . . . . . . . . . . . . . . . . . . . 1-4

.5 Regulatory Stabilization .. . . . . . . . . . . . . 1-4

1.6 NRC Review Criteria . . . . . . . . . . . . . . . . . . . 1-4

1.7 Format and Availability of Documentation . . . . . . . . 1-7

2 FOLICY ISSUES . . . . . . . . . . . . . . . . . 2-1

3 F.EVIEW BY THE ADVISORY COMMITTEE ON REACTOR SAFEGUARDS . . . . . . 3-1

4 CUTSTANDING ISSUES . . . . . . . . . . . . . . . . . . 4-1

4.1 Outstanding Issues Pertaining to the Requirements Document for Evolutionary Plant Designs . . . . . . . . . . . . . . .

4.2 Outstanding Issues Pertaining to the Requirements Document for Passive Plant Designs.... . . . . . . . . . . . 4-2

5 VENDOR- OR UTILITY-SPECIFIC ITEMS . . . . . . . . . . . . . 5-1

5.1 Vendor- or Utility-Specific Items Pertaining to the Requirements Document for Evolutionary Plant Designs . . . . . . . . . . . .

5.2 Vendor- or Utility-Specific Items Pertaining to the Requirements Document for Passive Plant Designs. . . . . . . . . . 5-21

6 CIONCLUSION . . . . . . . . . . . . . . . . . . 6-1

APPEINDIX A CHRONOLOGY OF CORRESPONDENCE . . . . . . . . . . . . . . A-1

APPEIIDIX B REFERENCES . . . . . . . . . . . . . . . . . . B-1

APPEIIDIX C LIST OF ABBREVIATIONS . . . . . . . . . . . . . . C $\mathrm{C}-1$

APPEIIDIX D PRINCIPAL CONTRIBUTORS . . . . . . . . . . . . . . . D-1

APPEIIDIX E COMMISSION PAPERS APPLICABLE TO ADVANCED LIGHT WATER

REACTORS . . . . . . . . . . . . . . . . . . E-1

APPENDIX $F$ REPORT BY THE ADVISORY COMMITTEE ON REACTOR SAFEGUARDS . . F-1 


\section{JNTRODUCTION}

The Electric Power Research Institute (EPRI) is preparing a compendium of techinical requirements, referred to as the "Advanced Light Water Reactor [ALWR] Utility Requirements Document," that is applicable to the design of an ALWF power plant. When completed, this document is intended to be a comprehensive statement of utility requirements for the design, construction, and performance of an ALWR power plant for the 1990s and beyond. Those participating in the program include utilities with nuclear plant experience, nuclear steam supply system vendors, architect-engineering firms, and consultants in related fields.

The Requirements Document consists of three volumes. Volume I, "ALWR Policy and Summary of Top-Tier Requirements," is a management-level synopsis of the Requirements Document, including the design objectives and philosophy, the overall physical configuration and features of a future nuclear plant design, and the steps necessary to take the proposed ALWR design criteria beyond the conceptual design state to a completed, functioning power plant. Volume II consists of 13 chapters and contains utility design requirements for an evolutionary nuclear power plant [approximately 1350 megawatts-electric (MWe)]. Volume III contains utility design requirements for nuclear plants (approximately $600 \mathrm{MWe}$ ) in which passive features will be used for the ultimate safety protection of the plant.

The staff of the Office of Nuclear Reactor Regulation, U.S. Nuclear Regulatory Commission (NRC), has prepared Volumes 1 and 2 (Parts 1 and 2) of its safety evaluation report (SER) to document the results of its review of Volume I and II of the Requirements Document. Volume 1, "NRC Review of Electric Power Research Institute's Advanced Light Water Reactor Utility Requirements Document - Program Summary," provides a discussion of the overall purpose and scope of the Requirements Document, the background of the staff's review, the review approach used by the staff, and a summary of the policy and technical issues raised by the staff during its review. Volume 2, "NRC Review of Electric Power Research Institute's Advanced Light Water Reactor Utility Requirements Document - Evolutionary Plant Designs," gives the results of the staff's review of the 13 chapters of the Requirements Document for evolutionary plant designs. Volume 3, "NRC Review of Electric Power Research Institute's Advanced Light Water Reactor Utility Requirements Document - Passive Plant Designs," scheduled to be issued in September 1993, will give the results of the staff's review of the 13 chapters of the Requirements Document for Jassive plant designs.

\subsection{Background and Review Status}

In 1:383, EPRI began its program by working with the NRC staff to identify and resolve key safety and licensing issues. This joint effort resulted in a procisss whereby the unresolved and generic safety issues applicable to ALWRs 
as of July 1, $1986^{*}$ were identified. This process was consistent with the procedures described in NUREG-0933, "A Prioritization of Generic Safety Issues." Additional information about this effort and its results is provided in NUREG-1197," Advanced Light Water Reactor Program - Program .Management and Staff Review Methodology," dated December 1986. In 1985, two new phases were added to the EPRI program: the development of EPRI's ALWR Utility Requirements Document for evolutionary plants and the assessment of small-plant options. This assessment resulted in the development of the Requirements Document for passive plant designs.

Chronology of Review of Requirements Document for Evolutionary Plant Designs

From June 30, 1986, through 0ctober 26, 1989, EPRI submitted Revision 0 of the Requirements Document for evolutionary plant designs. From September 24, 1987, through November 4, 1991, the staff developed and issued its draft SERs (DSERs) on these submittals. Table 1.1 gives the dates when these documents were issued.

On September 7, 1990, EPRI submitted Revision 1 of the Requirements Document for evolutionary plant designs, modifying the document in its entirety. On Apri1 26 and November 25, 1991, and Apri1 17, 1992, EPRI submitted Revisions 2, 3, and 4, respectively. Volume 2 of this report addresses the Evolutionary Document for evolutionary plant designs through Revision 3. Where possible, the staff's review included consideration of Revision 4 of the Requirements document.

A preliminary draft of Volume 2 was forwarded to the Commission and the Advisory Committee on Reactor Safeguards (ACRS) on May 12, 1992. The staff discussed the contents of the SER with the Committee and has included the views of the ACRS in Section 3 of this report.

Chronology of Review of Requirements Document for Passive Plant Designs

In its letter dated September 7, 1990, EPRI submitted Revision 0 of the Requirements Document for passive plant designs. On April 26, 1991, and January 2, 1992, EPRI submitted Revisions 1 and 2, respectively. In its letter dated April 24, 1992, the staff issued the DSER on all of the chapters of the Requirements Document for passive plant designs. After the staff has completed its review of EPRI's responses to this DSER in the form of revisions to the Requirements Document, it will issue a final SER as Volume 3 of this report to provide its conclusions regarding its review of the final version of the Requirements Document.

\subsection{Purpose and Regulatory Status of EPRI's ALWR Utility Requirements Document}

EPRI's ALWR Utility Requirements Document is designed to serve as a vehicle to obtain consistent resolution of common operating problems, issues generically applicable to designs, severe-accident issues, and certain unresolved and generic safety issues. The document is to be used with companion documents, such as utility procurement specifications, that cover the remaining technical

\footnotetext{
*This date has since been changed to January 1990.
} 
recuirements applicable to new plant projects. It is also designed to serve as a vehicle to identify early in the design process major concerns about design concepts for LWRs in which passive safety systems will be used.

EPFI's ALWR Utility Requirements Document, because it is an agreement between the vendors and the nuclear power utilities, identifies what utilities desire in future designs. The Requirements Document has no legal or regulatory stitus. It is not intended to demonstrate complete compliance with the Conimission's regulations, regulatory guidance, or policies, nor is it intended to be used as a basis for supporting final design approval and design certification (FDA/DC) for a specific design.

\section{Conmission Guidance}

In its staff requirements memorandum (SRM) dated December 15, 1989, the Conmission assigned the review of the Requirements Document for evolutionary plant designs priority equal to those of General Electric Company's Advanced Boiling Water Reactor and Combustion Engineering, Inc.'s System 80t. In adcition, the Commission directed the staff to compare future designs against the Requirements Document for evolutionary plant designs.

In the same SRM, the Commission directed the staff to complete its review of the Requirements Document for passive plant designs before it submitted the results of its review of the licensing review basis (LRB) for passive designs to the ACRS. Although a design certification applicant is no longer required to submit an LRB because the promulgation of Part 52 of Title 10 of the Code of Federal Regulations (10 CFR Part 52) negated the need for such a document, the staff interprets this guidance as directing it to complete its review of the Requirements Document for passive plant designs before significant interaction with the ACRS begins on these designs. It is the staff's position that, with the issuance of the DSER on Volume 3 in April 1992, this has been accompl ished.

In its SRM of June 22, 1990, the Commission directed the staff to formally resolve major technical and policy issues in the context of the review of the Requirements Document for passive plant designs. The staff has identified such issues during its review of Volume III of the ALWR Utility Requirements Document and conceptual design information on the passive ALWRs. The staff developed the draft Commission papers dated February 27 and July 6, 1992, to address resolution of these issues. To ensure timely resolution of these policy issues, the staff will continue to evaluate resolutions proposed by EPRI and the ALWR vendors, and will address them in future Commission papers.

\subsection{EPRI's Policy Statements}

The ALWR Utility Steering Committee established policies to provide guidance for the overall development of the EPRI's ALWR Utility Requirements Document and to provide the plant designer with guidance in applying the design criteria. Although not design criteria themselves, these policies cover fundamental principles that have a broad influence on the design criteria of the Requirements Document. These policies include consideration of simplification, design margin, human factors, safety, regulatory stabilization, 
standardization, use of proven technology, maintainability, constructibility, quality assurance, economics, protection against sabotage, and environmental effects.

\subsection{ALWR Design Bases}

The term "ALWR design bases," as defined by EPRI, refers to the three sets of requirements that form the foundation for the ALWR design criteria. The first set of requirements forms the "licensing design basis," which includes the requirements necessary to satisfy regulatory criteria. These requirements and associated analytical methods are based on conservative, NRC-approved methods, and equipment is designed to safety-grade standards. The second set is the "risk-evaluation-basis," which extends the licensing design basis to meet public safety objectives. Probabilistic risk assessments are used for the risk evaluation basis methods. The third set is the "performance design basis," which is based on economic and investment protection considerations for a utility and for which realistic, designer-selected, best-estimate methodology is used. EPRI states that the licensing design basis is intended to provide an adequate level of safety, whereas the risk evaluation and performance design bases provide additional or enhanced protection.

\subsection{Requlatory Stabilization}

Consistent with the overall ALWR program approach, as described in NUREG-1197, regulatory stabilization for an ALWR design can be achieved through the identification and resolution of plant optimization subjects and generic safety and licensing issues.

Plant optimization subjects are proposals, initiated by EPRI, to deviate from regulatory requirements. EPRI proposes to resolve these issues by providing technically supportable alternatives to current regulatory requirements. Table 1.2 contains a list of EPRI's proposed plant optimization subjects and their applicability to the evolutionary and passive plant designs. These issues are identified for both the evolutionary and passive plant design criteria in Section 2 of Appendix B to Chapter 1 of Volumes II and III of the Requirements Document. The staff's evaluation is provided in the corresponding sections of Volume 2 of this report and the April $1992 \mathrm{draft}$ of Volume 3 of this report.

In addition, EPRI specifically addressed those generic safety issues that were classified as "high" or "medium" priority as of January 1990 in Section 3 of Appendix B to Chapter 1 of Volumes II and III of the Requirements Document. The staff's evaluation of the generic safety issues specifically addressed by EPRI and those unresolved safety issues and generic safety issues that are considered applicable to ALWRs is provided in the corresponding sections of Volume 2 of this report and the April 1992 draft of Volume 3 of this report.

\subsection{NRC Review Criteria}

Criteria Governing the Review of EPRI's ALWR Utility Requirements Document

The staff's review of the Requirements Document is being conducted as described in NUREG-1197. As noted therein, the staff is using NUREG-0800, "Standard Review Plan [SRP] for the Review of Safety Analysis Reports for 
Nuclear Power Plants," for review guidance. In addition to the criteria of NUREG-0800, the staff's review reflects the requirements of 10 CFR Part 52, "Early Site Permits; Standard Design Certifications; and Combined Licenses for Nuclear Power Reactors," and the Commission's "Policy Statement on Severe Reactor Accidents Regarding Future Designs and Existing Plants" (50 FR 32138, August 8, 1985) and its policy statement on "Safety Goals for the Operations of Auclear Power Plants" (51 FR 28044, August 4, 1986).

The Requirements Document places primary emphasis on preventing significant protlems that have been experienced in existing plants; however, many details that will be provided in specific design applications are missing. Therefore, the staff is reviewing the proposed requirements at the level of detail presented by EPRI but is not determining their adequacy to meet all NRC requirements.

Although the SRP is being used as guidance, the level of detail does not permit a review for completeness. The SRP was written to support the review of safety analysis reports on specific plant designs for which a significant amount of design and construction information was available. Therefore, the staff's evaluation became one of "review by exception," and the staff is conducting its review with the understanding that EPRI intends that the Requirements Document contain design criteria that meet all current regulations, except where deviations are identified in the document. The staff's review of the Requirements Document is focused primarily on determining whether the EPRI criteria do or do not conflict with current regulatory requirements. If a requirement proposed by EPRI is found not to conflict with NRC requirements, the staff judges it to be acceptable.

However, in certain technical areas (e.g., advanced instrumentation and control design, human factors considerations), little or no requirements or guidance exists. Therefore, design criteria in the Requirements Document associated with these areas are unlikely to conflict with regulatory requirements. In those cases, although using the conflict standard would result in a finding of acceptability, the staff deems it appropriate to apply additional standards to judge the acceptability of a requirement. In such cases, the staff is using a combination of consideration of those regulations that do appliv, good engineering judgment, past practice and experience at operating power plants, and applications in other industries to evaluate the requirement; proposed by EPRI in the Requirements Document.

During its review, the staff also identified potential incompatibilities betwien EPRI-proposed design requirements and current regulatory requirements, and ivhere possible misinterpretations of regulatory requirements exist in the Requirements Document.

In the February 15, 1991, SRM pertaining to SECY-90-377, "Requirements for Desiugn Certification Under 10 CFR Part 52," the Commission directed the staff to risview the Requirements Document to ensure that it is sufficient to allow the :staff to evaluate the severe-accident issues and the incorporation of experience from operating events in current designs. The staff has used both deterministic and probabilistic methods of evaluation, considering how the Requirements Document addresses these issues through specific design criteria and through the guidelines it provides for performing a probabilistic risk asse:isment. 
In addition to addressing such matters relative to safety, the staff also has provided constructive comments on the document that, while not specifically regulatory in nature, would offer improvements in its requirements. The staff will review an actual ALWR plant in accordance with the most current version of the SRP and will follow the SRP criteria, except for those instances where the staff has specifically accepted other positions in EPRI's ALWR Utility Requirements Document and those positions have been endorsed in the final SER for the ALWR program.

Finally, as discussed in Section 1.2, the staff's review of the Requirements Document is not intended to substitute for any portion of the staff's review of future applications for final design approval and design certification.

\section{Additional Criteria Governing the Review of the Requirements Document for Passive Plant Designs}

The licensing design-basis analysis of the Requirements Document for passive plant designs relies solely on the passive safety systems to demonstrate compliance with the acceptance criteria for various design-basis transients and accidents. Consequently, uncertainties remain concerning the performance of the unique passive features and overall performance of core and containment heat removal because of lack of a proven operational performance history. For example, uncertainties exist about the performance of check valves in the passive safety systems, which operate at low differential pressures provided by natural circulation or gravity injection. These low pressures may not provide sufficient force to fully open sticking check valves (i.e., pumped emergency core cooling systems are more likely to overcome stuck valves). As a result, these uncertainties enhance the importance of the active non-safetyrelated systems in providing the defense-in-depth protection to prevent and mitigate accidents and core damage. Therefore, the review of the passive designs requires a review of not only the passive safety systems, but also the functional capability and availability of the active non-safety-related systems to provide significant defense-in-depth protection and the capability to prevent accidents and core damage.

For those active systems that perform defense-in-depth functions, the Requirements Document for passive plant designs specifies systems and equipment design and performance requirements. These include radiation shielding to permit access following an accident, the availability and redundancy of nonsafety-related electric power, and protection against internal hazards, as well as safety analysis and testing required to demonstrate system capability for defense-in-depth considerations. However, the Requirements Document does not provide specific requirements pertaining to the reliability of these systems. EPRI has indicated that it is evaluating the specific reliability targets and other measures to ensure that the passive plants will meet performance requirements and that it will address these safety concerns for both passive safety and active non-safety-related systems.

In addition, technical specification development is a subset of the overall regulatory treatment of the passive designs. The staff is evaluating the need to establish reliability-based technical specifications (TS) for the passive plant designs to determine which systems and components (including certain non-safety-related systems) will require the imposition of TS, and the 
parameters of the TS (limiting conditions for operation, surveillance, etc.). This reliability assurance program is expected to strongly influence TS.

Since the passive ALWR design philosophy departs from current licensing prictices, the staff has raised this issue to the Commission as a policy is:sue. The staff has not completed its review of this issue and, therefore, ha: not provided a recommendation to the Commission. This issue is discussed ful'ther in the staff's regulatory departure analysis, which is given in Appendix $B$ to the DSER on Chapter 1 of the Requirements Document for passive plant designs.

\section{1.: Format and Availability of Documentation}

Vo ume 1 of this report is a program summary of the NRC review of EPRI's ALWR Ut lity Requirements Document. It is not intended to provide a discussion of Vo: ume I of the Requirements Document (EPRI submitted Volume I for information on $y$ and did not request the staff to review it). Sections 1 through 5 provide a discussion of the overall purpose and scope of the Requirements Doc:ument and the results of the staff's review of that document. Section 6 giv'es the staff's conclusions regarding the review of the Requirements Documerit for the evolutionary plant designs and the status of the review of the Recluirements Documents for the passive plant designs. Appendix $A$ is a chronology of the correspondence related to the review of the document. Appendi): $B$ contains the references ${ }^{\star}$ for Volumes 1-3 of this report. Appendix $C$ is a list of abbreviations used in Volumes 1-3 of this report. Appendix $D$ is a list of principal contributors. Appendix $E$ is a list of Commission papers thi.t are applicable to the staff's review of the ALWR applications for FDA/DC. Aprendix $F$ is a copy of the report of the Advisory Committee Reactor Safegui.rds on the ALWR Utility Requirements Document.

The format of Volume 2 and the April 1992 draft of Volume 3 follows that of Volumes II and III of the Requirements Document as closely as possible.

Copies of Volumes 1 and 2 of this report and the April 1992 draft of Volume 3 are available for inspection at the NRC Public Document Room, $2120 \mathrm{~L}$ Street, N.h., Washington, DC 20555.

The NRC project managers for the staff's review of EPRI's ALWR Utility Recuirements Document are J. H. Wilson and T. J. Kenyon. They may be contacted by calling (301) 504-1118 or by writing to: Associate Directorate for Advanced Reactors and License Renewal, U.S. Nuclear Regulatory Commission, Washington, DC 20555.

${ }^{*}$ NR: : documents (e.g., NUREG reports and regulatory guides) are not included in Appendix $B$ because they may be retrieved as indicated in the "Availability Notice" on the inside front cover of this report. 
Table 1.1 Chronology of the Review of EPRI's Requirements Document for Evolutionary Plant Designs

\begin{tabular}{|c|c|c|c|}
\hline $\begin{array}{l}\text { Chap- } \\
\text { ter }\end{array}$ & Title & $\begin{array}{l}\text { Date of Submittal } \\
\text { of Revision } 0\end{array}$ & $\begin{array}{l}\text { Date DSER } \\
\text { Was issued }\end{array}$ \\
\hline 1 & Overall Requirements & $\begin{array}{l}\text { June } 30,1986 \\
\text { July } 8,1986\end{array}$ & $\begin{array}{l}\text { September } 24,1987 \\
\text { February } 18,1988\end{array}$ \\
\hline $1 A$ & $\begin{array}{l}\text { PRA Key Assumptions and } \\
\text { Groundrules }\end{array}$ & $\begin{array}{l}\text { June } 30,1989 \\
\text { February } 22,1990\end{array}$ & November 4, 1991 \\
\hline lB & $\begin{array}{l}\text { Licensing and Regulatory } \\
\text { Requirements and Guidance }\end{array}$ & None issued & None issued \\
\hline 2 & Power Generation Systems & October 15, 1986 & February 18, 1988 \\
\hline 3 & $\begin{array}{l}\text { Reactor Coolant System and } \\
\text { Reactor Non-Safety Auxiliary } \\
\text { Systems }\end{array}$ & $\begin{array}{l}\text { June } 18,1987 \\
\text { December } 11,1987\end{array}$ & May 13, 1988 \\
\hline 4 & Reactor Systems & June 18,1987 & June 10,1988 \\
\hline 5 & Engineered Safety Systems & December 8, 1987 & February 28, 1990 \\
\hline 6 & $\begin{array}{l}\text { Building Design and Arrange- } \\
\text { ment }\end{array}$ & November 18, 1988 & January 15, 1991 \\
\hline 7 & Fueling and Refueling Systems & February 28, 1989 & January 15, 1991 \\
\hline 8 & Plant Cooling Water Systems & December 30, 1988 & January 15, 1991 \\
\hline 9 & Site Support Systems & January 11, 1989 & January 15, 1991 \\
\hline 10 & Man-Machine Interface Systems & October 26, 1989 & October 8, 1991 \\
\hline 11 & Electric Power Systems & Apri1 10, 1989 & Apri1 3, 1991 \\
\hline 12 & $\begin{array}{l}\text { Radioactive Waste Processing } \\
\text { Systems }\end{array}$ & December 23, 1988 & January 15, 1991 \\
\hline 13 & Main Turbine-Generator Systems & February 6, 1989 & January 15, 1991 \\
\hline
\end{tabular}


Table 1.2 EPRI-Proposed Plant Optimization Subjects

\begin{tabular}{|c|c|c|}
\hline \multirow[b]{2}{*}{ Plint Optimization Subject } & \multicolumn{2}{|c|}{ Applicability } \\
\hline & Evolutionary & Passive \\
\hline $\begin{array}{l}\text { Operating-Basis Earthquake and Dynamic } \\
\text { Inalysis Methods }\end{array}$ & $x$ & $x$ \\
\hline Tornado Design & $x$ & $x$ \\
\hline $\begin{array}{l}\text { Boiling Water Reactor (BWR) Main Steamline } \\
\text { lsolation Valves and Leakage Control }\end{array}$ & $x$ & $x$ \\
\hline $\begin{array}{l}\text { Siniplification of Postaccident Sampling } \\
\text { Siystem }\end{array}$ & $x$ & $x$ \\
\hline $\begin{array}{l}\text { Type C Containment Leakage Rate Testing } \\
\text { Jnterval }\end{array}$ & $x$ & $x$ \\
\hline Source Term & $x$ & $x$ \\
\hline Decicated Containment Vent Penetration & $x$ & $x$ \\
\hline $\begin{array}{l}\text { Mitigation of Anticipated Transients } \\
\text { W'ithout Scram for the Advanced BWR }\end{array}$ & $x$ & $x$ \\
\hline $\begin{array}{l}\text { Simplification of Offsite Emergency } \\
\text { Flanning }\end{array}$ & $N / A$ & $x$ \\
\hline Safe Shutdown of Passive ALWRs & $N / A$ & $x$ \\
\hline
\end{tabular}




\section{POLICY ISSUES}

In the staff requirements memorandum (SRM) dated August 24, 1989, the Commission instructed the staff to provide an analysis detailing where the staff proposes departure from current regulations or where the staff is substantially supplementing or revising interpretive guidance applied to currently licensed light water reactors. The staff considers these to be policy issues. Appendix B to Chapter 1 of Volume 2 of this report gives the staff's regulatory analysis of those issues identified for the evolutionary plant designs. Appendix B to the DSER on Chapter 1 of Volume 3 of the Requirements Document gives the regulatory analysis of those issues identified for the passive plant designs. These issues have been addressed in Commission papers SECY-90-016, "Evolutionary Light Water Reactor Certification Issues and Their Relationship to Current Regulatory Requirements," and SECY-91-078, "Chapter 11 of the Electric Power Research Institute's Requirements Document and Additional Evolutionary Light Water Reactor Certification Issues, " and in draft Commission papers, "Issues Pertaining to Evolutionary and Passive Light Water Reactors and Their Relationship to Current Regulatory Requirements, " and "Design Certification and Licensing Policy Issues Pertaining to Passive and Evolutionary Advance Light Water Reactor Designs," that were issued on February 27 and July 6, 1992, respectively.

In its SRMs dated June 26, 1990, and August 15, 1991, the Commission provided its decisions on SECY-90-016 and SECY-91-078 as they apply to evolutionary designs.

The =ebruary 27 and July 6, 1992, draft Commission papers have been forwarded to the Advisory Committee on Reactor Safeguards. The staff will include its views in the final paper and document its final positions before seeking Commission approval. The approaches to resolving these issues have not been reviswed by the Commission, and, therefore, do not represent agency positions.

These policy issues are considered fundamental to agency decisions on the accejtability of the ALWR designs. To aid in identifying its positions, the staf. Commission papers discussed above. Table 2.1 contains a list of these policy issules and their applicability to the evolutionary and passive plant designs. Table 4B.1 of Appendix B to Chapter 1 of Volume 2 of this report lists the issules that are applicable to the Requirements Document for evolutionary plant desiugns with the cross-reference to the chapters and sections in which they are discussed. Table 5B.1 of Appendix B to Chapter 1 of the April $1992 \mathrm{draft}$ of Volume 3 of this report lists those issues that are applicable to the Requirements Document for passive plant designs at the time of issuance along with the appropriate cross-references.

In addition, Appendix E lists the papers that the staff has forwarded to the Commission regarding policy issues that the staff has identified to date for both evolutionary and passive ALWRs. The staff developed these papers as a resuit of its review of the EPRI's ALWR Utility Requirements Document, the fina design approval and design certification applications for the evolutionary 11 lants, and the conceptual design information on the passive plants. 
Table 2.1 Policy Issues Pertaining to the Evolutionary and Passive Plant Designs

\begin{tabular}{|c|c|c|}
\hline \multirow[b]{2}{*}{ Policy Issue } & \multicolumn{2}{|c|}{ Applicability } \\
\hline & Evolutionary & Passive \\
\hline Use of physically based source term & $x$ & $x$ \\
\hline Anticipated transients without scram & $x$ & $x$ \\
\hline Mid-1oop operation & $x$ & $N / A$ \\
\hline Station blackout & $x$ & $x$ \\
\hline Fire protection & $x$ & $x$ \\
\hline Intersystem loss-of-coolant accident & $x$ & $x$ \\
\hline Hydrogen control & $x$ & $x$ \\
\hline $\begin{array}{l}\text { Core-concrete interaction - Capability to } \\
\text { cool core debris }\end{array}$ & $x$ & $x$ \\
\hline High-pressure core melt ejection & $x$ & $x$ \\
\hline Containment performance & $x$ & $x$ \\
\hline Dedicated containment vent penetration & $x$ & $x$ \\
\hline Equipment survivability & $x$ & $x$ \\
\hline Elimination of operating-basis earthquake & $x$ & $x$ \\
\hline Inservice testing of pumps and valves & $x$ & $x$ \\
\hline Industry codes and standards & $x$ & $x$ \\
\hline Electrical distribution & $x$ & $x$ \\
\hline Seismic hazard curves & $x$ & $x$ \\
\hline Leak before break & $x$ & $x$ \\
\hline $\begin{array}{l}\text { Classification of main steamline of } \\
\text { boiling-water reactor }\end{array}$ & $x$ & $x$ \\
\hline Containment bypass & $x$ & $x$ \\
\hline
\end{tabular}


Table 2.1: (Continued)

\begin{tabular}{|c|c|c|}
\hline \multirow[b]{2}{*}{ Pol'cy Issue } & \multicolumn{2}{|c|}{ Applicability } \\
\hline & Evolutionary & Passive \\
\hline Torriado design basis & $x$ & $x$ \\
\hline Containment bypass & $x$ & $x$ \\
\hline Containment leak rate testing & $x$ & $x$ \\
\hline Postaccident sampling system & $x$ & $x$ \\
\hline Levell of detail & $x$ & $x$ \\
\hline Prototyping & $x$ & $x$ \\
\hline $\begin{array}{l}\text { Insfections, tests, analyses, and } \\
\text { acceptance criteria }\end{array}$ & $x$ & $x$ \\
\hline $\begin{array}{l}\text { Protabilistic risk assessment beyond } \\
\text { design certification }\end{array}$ & $x$ & $x$ \\
\hline Reliability assurance program & $x$ & $x$ \\
\hline $\begin{array}{l}\text { Severe-accident mitigation design } \\
\text { alternatives }\end{array}$ & $x$ & $x$ \\
\hline $\begin{array}{l}\text { Generic rulemaking related to design } \\
\text { certification }\end{array}$ & $x$ & $x$ \\
\hline $\begin{array}{l}\text { Regulatory treatment of non-safety- } \\
\text { related systems }\end{array}$ & N/A & $x$ \\
\hline Definition of passive failure & $N / A$ & $x$ \\
\hline $\begin{array}{l}\text { Thermal-hydraulic stability of the } \\
\text { simplified boiling water reactor }\end{array}$ & $N / A$ & $x$ \\
\hline Safe shutdown requirements & N/A & $x$ \\
\hline Control room habitability & N/A & $x$ \\
\hline Radionuclide attenuation & $N / A$ & $x$ \\
\hline $\begin{array}{l}\text { Simplification of offsite emergency } \\
\text { planning }\end{array}$ & N/A & $x$ \\
\hline
\end{tabular}


Table 2.1 (Continued)

\begin{tabular}{lcc}
\hline & \multicolumn{2}{c}{ Applicability } \\
\cline { 2 - 3 } Policy Issue & Evolutionary & Passive \\
\hline $\begin{array}{l}\text { Defense against common-mode failures in } \\
\text { digital instrumentation and control }\end{array}$ & $\mathrm{X}$ & $\mathrm{X}$ \\
$\begin{array}{l}\text { Analysis of external events beyond the } \\
\text { design basis }\end{array}$ & $\mathrm{X}$ & $\mathrm{X}$ \\
$\begin{array}{l}\text { Multiple steam generator tubes ruptures } \\
\text { Role of the passive plant control room } \\
\text { operator }\end{array}$ & $\mathrm{N} / \mathrm{A} / \mathrm{A}$ & $\mathrm{X}$ \\
$\begin{array}{l}\text { Control room annunciator reliability } \\
\text { N/A }=\text { not applicable }\end{array}$ & $\mathrm{X}$ & $\mathrm{X}$ \\
\end{tabular}




\section{REVIEW BY THE ADVISORY COMMITTEE ON REACTOR SAFEGUARDS}

In September 1984, the NRC staff, EPRI, and the Advisory Committee on Reactor Safeguards (ACRS) met to discuss early efforts leading to the development of EPRI's ALWR Requirements Document. Since that time, these parties have met periodically to discuss the programmatic aspects and progress of EPRI's ALWR program.

The ACRS met with the staff and EPRI numerous times during the period 0ctober 1987 through January 1992 to discuss the contents of each chapter of Volume II of the ALWR Requirements Document and corresponding DSER after issuance of the documents. Each chapter and DSER was discussed with the ACRS Subcommittee on Improved Light Water Reactors one or more times.

In addition, many of the policy issues identified in Appendix B to Chapter 1 of Volume 2 were discussed with the Committee. The reports of the ACRS and the staff's responses to their comments on these policy matters are in Annexes A-C of Appendix B to Chapter 1 of Volume 2 of this report.

The staff met with the ACRS Subcommittee on Improved Light Water Reactors to discuss the May $1992 \mathrm{draft}$ of the SER on Volume II of the ALWR Requirements Docuinent on June 17 and 18, and July 27, 1992. The staff met with the ACRS Full Committee to discuss the results of its review of Volume II during the $387 \mathrm{t}$, and 388th meetings of the ACRS on July 10 and August 7, 1992, respectively. A copy of the ACRS report on Volume II of EPRI's ALWR Utility Requirements Document, dated August 18, 1992, is attached as Appendix F.

The staff will continue to interact with the ACRS during its review of policy issues and any additional issues on evolutionary ALWRs that may be resolved in the :ontext of Volume II of the ALWR Utility Requirements Document. In addition, the staff will continue to interact with the ACRS during its review of Vislume III of the ALWR Utility Requirements Document and will report the results of the Committee's review of that document and the staff's SER when it is cimpleted. 


\section{IUTSTANDING ISSUES}

During its review of EPRI's ALWR Utility Requirements Document, the staff idertified several items for which additional information is required before the staff can reach a final conclusion. The staff considers these issues to be cutstanding. These outstanding issues fall into one of three categories: (1) open policy issues on which the staff has taken a position, but for which the Commission has not provided guidance; (2) open issues that must be satisfactorily resolved before the staff can complete its review of the Requirements Document; or (3) confirmatory issues for which the staff will ensure that EPRI meets it commitments to revise the Requirements Document. The outstanding issues for the entire Requirements Document, provided by chapter or appendix with references to appropriate sections of the SER chapter or appendix given in parentheses, are listed below.

The designators in front of each issue provide a unique identifier for each issue. The letter "E" or "P" indicates that the issue applies to evolutionary or passive plant designs, respectively. The first number designates the chapter in which it is identified. The letter that follows designates the appendix, if applicable. The letter " 0 " or " $C$ " designates whether it is an open or a confirmatory issue, respectively. The final number is the sequential number assigned to it in Section 1.4 of each chapter or appendix.

\subsection{Outstanding Issues Pertaining to the Requirements Document for Evolutionary Plant Designs}

\section{OPEN ISSUES}

The following is a list of open policy issues pertaining to the Requirements Doculnent for evolutionary plant designs (Volume II) on which the staff has takein a position, but for which the Commission has not had the opportunity to provide guidance. There are no other types of open issues resulting from the staff's review of the Requirements Document for evolutionary plant designs.

Chapter 1 - Overall Requirements

E.1.1)-1 tornado wind speeds (4.5.2)

E.1.1)-2 leak before break (4.5.5)

Appelldix B to Chapter 1 - Licensing and Regulatory Requirements and Guidance

E.1B.0-1 impact of the elimination of the operating-basis earthquake from the design process (2.1.1, Item IV.A of Annex A, and Item I.M of Annex $C$, Item $C$ of Annex D)

E.1B.0-2 applicability of industry codes and standards (2.1.1 and Item II.A of Annex ())

E.1B.0-3 tornado design basis (2.1.2 and Item II.F of Annex C) 
E.1B.0-4 main steamline classification (2.3.1.1 and Item II.E of Annex C)

E.1B.0-5 simplification of postaccident sampling system (2.3.2 and Item II.I of Annex C)

E.1B.0-6 containment leak rate testing (2.5.1 and Item II.H of Annex C)

E.1B.0-7 source term (2.5.2.1, 2.5.2.2, Item I.B of Annex A, and Item I.A of Annex C)

E.1B.0-8 seismic hazard curves (Item II.C of Annex C)

E.1B.0-9 leak before break (Item II.D of Annex C)

E.1B.0-10 containment bypass (Item II.G of Annex C)

E.1B.0-11 prototyping (Item II.K of Annex C)

E.1B.0-12 reliability assurance program (Item II.M of Annex C)

E.1B.0-13 defense against common-mode failures in digital instrumentation and control systems (Item A of Annex D)

E.1B.0-14 analysis of external events beyond the design basis (Item B of Annex D)

E.1B.0-15 control room annunciator reliability (Item $G$ of Annex D)

Chapter 5 - Engineered Safety Systems

E.5.0-1 core debris coolability (6.6.2)

\section{CONFIRMATORY ISSUES}

There are no confirmatory issues pertaining to the Requirements Document for evolutionary plant designs.

\subsection{Outstanding Issues Pertaining to the Requirements Document for Passive Plant Designs}

OPEN ISSUES

The following is a list of open issues that must be resolved before the staff can complete its review of the Requirements Document for passive plant designs (Volume III).

Chapter 1 - Overall Requirements

P.1.0-1 scope of mitigation requirements (2.1 and 2.4)

P.1.0-2 regulatory treatment of non-safety-related systems (2.3.1, 4.3.1, $7,10,12.2 .1,12.2 .3$, and Appendix B) 
P.1.1)-3 automatic standby liquid control system for passive boiling-waterreactor (BWR) design (2.3.2 and Appendix $B$ )

P.1.1)-4 check valve categorization $(2.3 .2)$

P.1.1)-5 tornado wind speeds (4.5.2.5)

P.1.1)-6 leak before break (4.5.5)

P.1.1)-7 seismic evaluation and design of small-bore piping (4.7.3)

P.1.1)-8 use of Institute of Electrical and Electronics Engineers (IEEE) Standard 323 (4.8.2)

P.1.()-9 method of environmental qualification of mechanical and electrical equipment (4.8.2)

P.1.0-10 limits on nitrites, nitrates, and total halogens as chlorine $(5.2 .8)$

P.1.0-11 pressurized-water-reactor (PWR) water chemistry (5.5.2)

P.1.(1)-12 reliability assurance program framework (6.2)

P.1.(1)-13 quantitative reliability and availability goals (6.2)

P.1.(1)-14 integration of reliability engineering techniques $(6.2,6.3$, and 6.4)

P.1.(1-15 relationship of system requirements to overall plant safety reliability and availability goals (6.2)

P.1.(1-16 difference between reliability assurance program for safety- and non-safety-related systems (6.3)

P.1.(1-17 human factors considerations for operation and maintenance provisions (8.2)

P.1.(1-18 computer security reference (11.12)

Apperdix A to Chapter 1 - PRA Key Assumptions and Groundrules

P.1A.0-1 reporting of core-damage-frequency results as mean values (1.7)

P.1A.0-2 point-estimate quantification (1.8)

P.1A.0-3 quantitative treatment of uncertainties (1.9)

P.1A.0-4 guidance on presenting results of probabilistic risk assessment (PRA) (1.10)

P.1A.0-5 guidance on modeling detail required to represent passive system behavior (2.1) 
P.1A.0-6 guidance on modeling interactions between passive and active systems (2.1)

P.1A.0-7 guidance for developing the success criteria for passive systems (2.3)

P.1A.0-8 determination of an appropriate mission time (2.10)

P.1A.0-9 requirements to address the important passive design-specific areas of uncertainty (6.1)

P.1A.0-10 failure rate for the main step-up transformers (8.2)

Appendix B to Chapter 1 - Licensing and Requlatory Requirements and Guidance

P.1B.0-1 impact of the elimination of the OBE from the design process $(2.1 .1,3.3 .1$, and Item I.M of Annex A)

P.1B.0-2 applicability of industry codes and standards (2.1.1 and Item II.A of Annex A)

P.1B.0-3 tornado design basis (2.1.2 and Item II.F of Annex A)

P.1B.0-4 simplification of emergency planning requirements $(2.1 .3$ and Item III.G of Annex A)

P.1B.0-5 need for leakage control system for main steam isolation valves (2.3.1 and Item II.E of Annex A)

P.1B.0-6 main steam isolation valve leakage rate (2.3.1 and Item II.E of Annex A)

P.1B.0-7 simplification of postaccident sampling system (2.3.2 and Item II. I of Annex A)

P.1B.0-8 containment leak rate testing (2.5.1 and Item II.H of Annex A)

P.1B.0-9 source term (2.5.2 and Item I.A of Annex A)

P.1B.0-10 hydrogen generation and control (2.5.3, 3.2.26 and Item I.G of An$\operatorname{nex} A$ )

P.1B.0-11 safe shutdown requirements (2.5.6 and Item III.D of Annex A)

P.1B.0-12 revised deficiency reporting requirements (Generic Safety Issue II.J.4.1) (3.2.3)

P.1B.0-13 criteria for safety-related operator actions (Generic Safety Issue B-17) $(3.2 .5)$

P.1B.0-14 diesel generator reliability (Generic Safety Issue B-56) (3.2.6)

P.1B.0-15 allowable emergency core cooling system equipment outage periods (Generic Safety Issue B-61) (3.2.7) 
P.1B.0-16 reactor coolant pump seal failures (Generic Safety Issue 23) $(3.2 .10)$

P.1B.0-17 bolting degradation or failure (Generic Letter 91-17) (Generic Safety Issue 23) (3.2.12)

P.1B.0-18 use of EPRI NP-5076 on good bolting practices for bolted joints (3.2.12)

P.1B.0-19 bolting degradation or failure (Generic Safety Issue 29) (3.2.12)

P.13.0-20 effects of fire protection system actuation on safety-related equipment (Generic Safety Issue 57) (3.2.13)

P.13.0-21 power-operated relief valve and block valve reliability (Generic Safety Issue 70) (3.2.14)

P.13.0-22 anticipated transients without scram (Generic Safety Issue 75) (3.2.16 and Item I.B of Annex A)

P.13.0-23 unanalyzed reactor vessel thermal stress during natural convection cooldown (Generic Safety Issue 79) (3.2.17)

P.13.0-24 control room habitability (3.2.18)

P.1B.0-25 low-temperature overpressure protection (Generic Safety Issue 94) $(3.2 .21)$

P.1B.0-26 piping and use of highly combustible gases in vital areas (Generic Safety Issue 106) (3.2.23)

P.11.0-27 dynamic qualification and testing of large-bore hydraulic snubbers (Generic Safety Issue 113) (3.2.24)

P.1L.0-28 reliability, operability, and on-line testability of the final actuation contacts in protection systems (3.2.25)

P.1E.0-29 essential service water pump failures at multiplant sites (Generic Safety Issue 130) (3.2.29)

P.1E.0-30 guidelines for upgrading other procedures (Generic Safety Issue HF 4.4) (3.2.33)

P.1E.0-31 electronic display of procedures, use of mixed types of procedures from one control station to another, and use of active simulator to validate procedures $(3.2,33)$

P.1E.0-32 clarification of definition of local control stations (3.2.34)

P.1E.0-33 centralization of safety functions $(3.2 .34)$

P.1B.0-34 development of a human factors verification and validation test plan (3.2.35) 
P.18.0-35 documentation of test activities for traceability and assurance that all human factors requirements are addressed during test and evaluation (3.2.35)

P.1B.0-36 development of quantitative measures to assess human-system performance (3.2.35)

P.1B.0-37 uniform damping values (3.3.1)

P.1B.0-38 modal combination of high-frequency modes for vibratory loads (3.3.1)

P.1B.0-39 safety implications of control systems (Generic Safety Issue A-47) $(3.3 .3)$

P.1B.0-40 heat exchanger testing (3.3.4)

P.1B.0-41 control of biofouling (3.3.4)

P.1B.0-42 zebra mussel fouling (3.3.4)

P.1B.0-43 mid-loop operation (Item I.C of Annex A)

P.1B.0-44 station blackout (Item I.D of Annex A)

P.1B.0-45 fire protection (Item I.D of Annex A)

P.1B.0-46 intersystem loss-of-coolant-accident (Item I.E of Annex A)

P.1B.0-47 core-concrete interaction - capability to cool core debris (Item I.G of Annex $A$ )

P.1B.0-48 high-pressure core melt ejection (Item I.I of Annex A)

P.1B.0-49 containment performance (Item I.J of Annex A)

P.1B.0-50 dedicated containment vent penetration (Item I.K of Annex A)

P.1B.0-51 equipment survivability (Item I.L of Annex A)

P.1B.0-52 inservice testing of pumps and valves (Item I.N of Annex A)

P.1B.0-53 electrical distribution (Item II.B of Annex A)

P.1B.0-54 seismic hazard curves (Item II.C of Annex A)

P.1B.0-55 leak before break (Item II.D of Annex A)

P.1B.0-56 classification of main steaml ine of BWB (Item II.E of Annex A)

P.1B.0-57 containment bypass (Item II.G of Annex A)

P.1B.0-58 level of detail (Item II.J of Annex A) 
P.1B.0-59 prototyping (Item II.K of Annex A)

P.1B.0-60 inspections, tests, analyses, and acceptance criteria (Item II.L of Annex A)

P.1B.0-61 reliability assurance program (RAP) (Item II.M of Annex A)

P.1B.0-62 site-specific PRAs (Item II.N of Annex A)

P.1B.0-63 severe-accident mitigation design alternatives (Item II.0 of Annex A)

P.1B.0-64 generic rulemaking related to design certification (Item II.P of Annex A)

P.1B.0-65 regulatory treatment of non-safety systems (Item III.A of Annex A)

P.1B.0-66 definition of passive failure (Item III.B of Annex A)

P.1B.0-67 thermal-hydraulic stability of the Simplified Boiling Water Reactor (Item III.C of Annex A)

P.1B.0-68 control room habitability (Item III.E of Annex A)

P.1B.0-69 radionuclide attenuation (Item III.F of Annex $A$ )

Chap:er 2 - Power Generation Systems

P.2.1)-1 safety valve design (3.4)

Chap:er 3 - Reactor Coolant System and Reactor Non-Safety Auxiliary Systems

P.3.1)-1 leak-testing of feedwater system valve that performs containment isolation function (5.5)

P.3.(1)-2 postaccident sampling system (7)

\section{Chapt:er 4 - Reactor Systems}

P.4.(1-1 rod insertion capability after an earthquake $(2.2 .6)$

P.4.(1-2 inservice inspection of reactor pressure vessel (RPV) internals (2.3.2)

P.4.(1-3 RPV thermocouples (3.3)

Chapter 5 - Engineered Safety Systems

P.5.(1-1 justification for 72-hour design-basis period for control room habitability $(2.1 .1,2.2$, and 6.5)

P.5.C-2 need for activated charcoal filters (2.1.2)

P.5.C-3 timing of fission product release (2.1.3) 

P.5.0-4 evaluation of aerosol fission product removal (2.1.6)
P.5.0-5 secondary building fission product holdup and plateout (2.1.7 and 6.4)
P.5.0-6 chemical form of iodine in containment (2.1.9)
P.5.0-7 guidance on vendor-supplied information (2.4.2)
P.5.0-8 identification of vital equipment (2.5)
P.5.0-9 use of carbon austenitic stainless steel for passive decay heat removal (PDHR) heat exchanger piping material (3.3)
P.5.0-10 diverse reactor protection system (RPS) input to control rods (3.4)
P.5.0-11 definition of the safe shutdown condition (4.3)
P.5.0-12 PDHR water pool capacity (4.3)
P.5.0-13 gravity drain tank for standby liquid control system (4.5)
P.5.0-14 separate connecting line for the two trains of the automatic depressurization system final stage (5.4)
P.5.0-15 elimination of Type C leakage rate testing (6.2)
P.5.0-16 Type B air lock leak test interval requirements (6.3)
P.5.0-17 dose consequence criteria for design-basis accidents (6.4)
P.5.0-18 maximum interval for Type $C$ leakage rate testing (6.3)
P.5.0-19 need for safety-grade containment spray system and engineered safety features atmosphere cleanup (2.1.6 and 6.4)
P.5.0-20 thyroid and beta skin radiation dose 1 imits and credit for long- term use of breathing apparatus (6.5)
P.5.0-21 hydrogen concentration for PWR dry containment (6.6)
P.5.0-22 allowable compressive stress consistent with the American Society of Mechanical Engineers Boiler and Pressure Vessel Code $(6.6)$
P.5.0-23 safety-grade hydrogen recombiners system (6.6)
P.5.0-24 containment steam bypass capability consistent with Standard Review Plan (7.2)
Chapter 6 - Building Design and Arrangement

P.6.0-1 classification of non-safety-grade auxiliary systems as vital equipment (2.3.3) 

P.9.0-10 omission of cooling coil supplied by chilled water for reactor cavity system $(8.4 .1)$

P.9.0-11 use of Uniform Building Code, Zone 2A (8.5)

P.9.0-12 power source and performance requirements following a loss of offsite power (8.5)

P.9.0-13 HVAC design for several areas not required to meet requirements specified in the General Design Criteria, Standard Review Plan, or regulations $(8.5)$

Chapter 10 - Man-Machine Interface Systems (M-MIS)

P.10.0-1 independence of the software verification and validation review teams $(3.1 .2,3.1 .4$, and 6.1 .5$)$

P.10.0-2 use of commercial compilers for software used in safety systems $(3.1 .2)$

P.10.0-3 dedication of commercial-grade software (3.1.2)

P.10.0-4 clarification of requirements for analysis and validation testing of M-MIS (3.1.3)

P.10.0-5 use of rapid prototyping in the development and validation of functional specifications (3.1.3)

P.10.0-6 operator aids (3.4.5)

P.10.0-7 establishment and use of reliability and availability estimates (3.5)

P.10.0-8 definition of "practical" (3.5.3).

P.10.0-9 environmental conditions for equipment design including compatibility with tasks (3.5.3)

P.10.0-10 component reliability of M-MIS (3.5.4)

P.10.0-11 overall reliability of M-MIS (3.5.4)

P.10.0-12 sneak circuit analysis (3.5.4)

P.10.0-13 software maintenance (3.5.4)

P.10.0-14 minimum tests for continuous on-1ine testing (3.6.1)

P.10.0-15 vulnerability of power supplies for alarm systems (4.3.1)

P.10.0-16 guidance on criteria to establish priorities (4.3.4)

P.10.0-17 guidance on the maximum number of alarms $(4.3 .4)$ 
P.10.0-18 alarm sequence recording (4.3.4)

P.10.0-19 valve position indication (4.4)

P.10.0-20 guidance on frequency allocation plan (4.6)

P.10.0-21 guidance on interference between communication systems and M-MIS equipment (4.6)

P.10.0-22 environmental conditions for minimally used local control stations (4.9.2)

P.10.0-23 guidance on inadvertent actuation of-controls at local control stations (4.9.2)

P.10.0-24 special physical security measures for the data transmission cable (5.2.1)

P.10.0-25 guidance on data system characteristics (5.2.2)

P.10.0-26 propagation of common-mode failures through the data system (5.2.2)

P.10.0-27 expansion capability of multiplexers (5.2.3)

P.10.0-28 reliability of multiplexing system (5.4)

P.10.0-29 software design aids and tools (6.1.1 and 6.1.5)

P.10.0-30 quality assurance requirements for safety-related software (6.1.2)

P.10.0-31 configuration management requirement for software (6.1.2)

P.10.0-32 software integrity (6.1.2)

P.10.0-33 guidance on software user documentation (6.1.2)

P.10.0-34 acceptance testing of commercially available software (6.1.2)

P.10.0-35 notification of software errors or modifications of commercially delivered software products (6.1.2)

P.10.0-36 long-term configuration control of software (6.1.2)

P.10.0-37 clarification of top-down structured design approach (6.1.3)

P.10.0-38 guidance on convolution of software structure (6.1.3)

P.10.0-39 behavior of commercial software when assumptions are violated (6.1.3)

P.10. J-40 guidance on memory protection (6.1.3)

P.10.J-41 use of information by redundant safety channels (6.1.3) 
P.10.0-42 guidance on tools to improve reliability and quality of software (6.1.5)

P.10.0-43 definition of reasonable testing and degree of confidence to be considered (6.1.5)

P.10.0-44 specification of the level of diversity in safety systems (6.1.6, 6.2.3, and 6.2.5)

P.10.0-45 guidance on performance of reliability evaluation (6.1.6)

P.10.0-46 reference to IEEE 1050-1989 (6.2.2 and 6.2.9)

P.10.0-47 compatibility between M-MIS equipment and its external power supply systems (6.2.2)

P.10.0-48 alarmed, self-diagnostic feature on clock update $(6.2 .3)$

P.10.0-49 guidance on position of sensor isolation valves (6.2.5)

P.10.0-50 capacitance-type pressure sensors (6.2.5)

P.10.0-51 minimal acceptance review criteria for isolation device (6.2.6)

P.10.0-52 voltage design of battery and dc system (6.2.8)

P.10.0-53 standards for surge suppression (6.2.8)

P.10.0-54 electromagnetic interference/radiofrequency interference (EMI/RFI) considerations for wiring shields (6.2.9)

P.10.0-55 specific grounding standards (6.2.9)

P.10.0-56 use of qualified isolators for wiring shields (6.2.9)

P.10.0-57 requirements for signal reconstruction (6.3.3)

P.10.0-58 use of interrupts (6.3.3)

P.10.0-59 redundancy of safety systems (6.3.4)

P.10.0-60 selection of automatic or manual control (7.2)

P.10.0-61 operation of plant by load dispatcher (7.3.2)

P.10.0-62 alternate means of inventory monitoring (7.13)

P.10.0-63 clarification of actuation logic self-testing (8.2.3)

P.10.0-64 initiation of standby liquid control system (8.7)

P.10.0-65 inclusion of four elements in human factors organizational structure (3.1.2 of Appendix B) 
P.10.0-66 scheduling of human factors studies before start of control room design process (3.1.3 of Appendix B)

P. 10.0-67 guidance to the M-MIS designer to overcome past problems (3.1.4 of Appendix B)

P.10.0-68 guidance to improve interfaces between the operator and the plant (3.1.4 of Appendix B)

P.10.0-69 identification of human factors criteria, guidance, etc., that were used as the supporting bases for M-MIS requirements (3.2.1 of Appendix B)

P.10.0-70 traceability of human factors requirements to original source (3.2.2 of Appendix B)

P.10.0-71 method for establishing effective human factors requirements (3.2.3 of Appendix B)

P.10.0-72 guidance on systems analysis (3.2.4 of Appendix B)

P.10.0-73 organization of plant information (3.2.4 of Appendix B)

P.10.0-74 configuration of operator's workstation (3.2.5 of Appendix B)

P.10.0-75 human factors guidelines for new technology (3.3 of Appendix B)

P.10.0-76 illumination levels (3.3 of Appendix B)

P.10.0-77 maintenance procedures ( 3.4 of Appendix $B$ )

P.10.0-78 selection and qualification of plant personnel (3.5 of Appendix B)

P.10.0-79 training requirements for top-level personnel (3.6 of Appendix B)

P.10.0-80 human factors verification and validation test plan (3.7.1 of Appendix B)

P.10.0-81 documentation of human factors test activities (3.7.2 of Appendix B)

P.10.0-82 team performance (3.7.4 of Appendix B)

Chapter 11 - Electric Power Systems

P.11.0-1 regulatory treatment of active non-safety systems $(2.2 .1,3.2 .2$, $5.2 .1,5.2 .4,5.2 .5$, and 8.2 .1 )

P.11.J-2 clarification of terminology describing the role of non-safety systems $(2.2 .1)$

P.11.J-3 loss of non-safety ac power during shutdown conditions (2.2.6) 
P.11.0-4 second offsite power supply circuit for permanent non-safety load buses during power operations (3.2.1)

P.11.0-5 consistency of Appendix A to Chapter 1 assumptions with Chapter 11 (3.2.3)

P.11.0-6 data provided in Appendix A to Chapter 1 relative to loss-ofoffsite-power events $(3.2 .5)$

P.11.0-7 non-safety ac electrical power systems during a small-break lossof-coolant accident (5.2.1)

P.11.0-8 clarification of revised requirements in Sections 1.5 .2 and $5.3 .1 .1(5.2 .1)$

P.11.0-9 applicability of the 2000-hour rating and its impact on peaking operation (5.2.1)

P.11.0-10 peaking operation of non-safety standby power sources (5.2.3)

P.11.0-11 consistency of failure and unavailability rates in Appendix $A$ to Chapter 1 (5.2.4)

P.11.0-12 justification for the use of independent self-contained cooling systems $(5.2 .6)$

P.11.0-13 potential loss of dc buses (7.2.1)

P.11.0-14 load shedding for 72-hour battery endurance (7.2.3)

P.11.0-15 backup battery and battery charger (7.2.4)

P.11.0-16 transfer scheme for the safety dc power supply system (7.2.5)

P.11.0-17 battery and battery charger instrumentation and alarms (7.2.8)

P.11.0-18 lack of requirements for electric protective assemblies in RPS power for BWRs (7.2.9)

\section{Chapter 12 - Radioactive Waste Processing Systems}

P.12.0-1 source term basis for designing radioactive waste systems and evaluation of offsite effluent radioactive nuclide concentration (2.2.2)

P.12.0-2 basis for 2-minute-delay requirement for BWR turbine gland seal system exhaust $(3.3 .1)$

P.12.0-3 production sources for essentially nonradioactive steam (3.3.1)

P.12.0-4 discrepancy between Figure 12.3-1 and requirement in Chapter 13 $(3.3 .1)$ 
P.12.0-5 use of post-filter downstream of charcoal adsorber in ventilation exhaust systems (3.3.3)

P.12.0-6 guidance regarding direct piping from radioactive plant systems to sumps or waste collection tanks (BWR) (4.2)

P.12.0-7 requirements for 1 iquid radioactive waste processing systems (LRWPS) filter housing and components (4.2)

P.12.0-8 requirements for LRWPS filters (4.2)

P.12.0-9 requirements for LRWPS ion exchangers (4.2)

Chapter 13 - Main Turbine-Generator Systems

P.13.0-1 turbine missile generation probability effect on safety-related systems or components $(3.1 .4)$

P.13.0-2 inservice inspection interval for turbine steam valves (3.3)

\section{CONFIRMATORY ISSUES}

The following is a list of confirmatory issues for which the staff will ensure that EPRI meets its commitments to revise the Requirements Document for passive plant designs.

Chapter 1 - Overall Requirements

P.1.C-1 tornado wind speeds $(4.5 .2)$

P.1.C-2 internal flooding design criteria (4.5.5)

P.1.C-3 compliance with Regulatory Guides 1.26 and 1.29 (9)

Appendix A to Chapter 1 - Key Assumptions and Groundrules

Nones

Appendix B to Chapter 1 - Licensing and Requlatory Requirements and Guidance

P.13.C-1 commitments to 10 CFR Part 21 and 50.55 (e) (3.2.3)

P.13.C-2 Target Rock safety/relief valves (3.2.5)

Chajter 2 - Power Generation Systems

Noni?

Chajter 3 - Reactor Coolant System and Reactor Non-Safety Auxiliary Systems

P.3.C-1 anticipated-transients-without-scrams events (5.5)

Chajter 4 - Reactor Systems 
None

Chapter 5 - Engineered Safety Systems

None

Chapter 6 - Building Design and Arrangement

None

Chapter 7 - Fueling and Refueling Systems

P.7.C-1 quality group classification of components for the new and spent fuel storage racks $(2.3 .1)$

Chapter 8 - Plant Cooling Water Systems

None

Chapter 9 - Site Support Systems

P.9.C.1 guidance on the need for assessing the area interior to security detection equipment $(5.2 .7)$

Chapter 10 - Man-Machine Interface Systems

P.10.C-1 intention of use (1)

P.10.C-2 impact of support software on installed software (6.1.2)

P.10.C-3 software common-mode failures $(6.1 .6,6.2 .5$, and 8.2.1)

P.10.C-4 BWR depressurization system design change (8.6)

P.10.C-5 manning of M-MIS that controls security functions (10.2.3)

Chapter 11 - Electric Power Systems

P.11.C-1 isolation of safety systems from their non-safety sources (2.2.5)

P.11.C-2 minimum starting voltages for valve actuator motors (2.2.8)

P.11.C-3 requirements for main step-up transformers (3.2.6)

P.11.C-4 harmonic distortion effect of adjustable speed drives (4.2.3)

P.11.C-5 location of non-safety standby ac power sources (5.2.2)

P.11.C-6 sizing of thermal overload devices $(6.2 .1)$

P.11.C-7 battery sizing criteria specified for 72-hour coping capability $(7.2 .2)$

P.11.C-8 physical and electrical separation of the safety dc and low-voltage 
vital ac power supply system (7.2.5)

P.11.C-9 non-safety dc power supplies for switchyard circuit protection and control equipment (7.2.6)

P.11.C-10 battery capacity margin (7.2.7)

P.11.C-11 normal and emergency lighting following design-basis events (8.2.1)

P.11.C-12 intensity of emergency lighting system (8.2.2)

Chapter 12 - Radioactive Waste Processing Systems

None

Chapter 13 - Main Turbine-Generator Systems

P.13.C-1 compliance with Regulatory Guide 1.29 seismic design classification (3.1.1)

P.13.C-2 compliance with Standard Review Plan quality group classifications (3.1.2) 


\section{VENDOR- OR UTILITY-SPECIFIC ITEMS}

During its review of EPRI's ALWR Utility Requirements Document, the staff identified items that were inadequately addressed in the document or were issu?s that could not be addressed generically. These items will have to be satisfactorily resolved during the staff's review of a vendor- or utilityspecific application (i.e., an application for final design approval and design certification or a combined construction permit and operating license).

As discussed in Section 1.2 of this report, the Requirements Document has no legal or regulatory status and is not intended to demonstrate complete compliance with the Commission's regulations, regulatory guidance, or policies. It is not intended to be used as a basis for supporting final design approval and design certification for a specific design, nor is it to be used to substitute for any portion of the staff's review of future applications for final design approval and design certification. Specifically, satisfactory resolution of the items identified in this section for a vendor- or utilityspecific application will not, by itself, support a finding that the application complies with the Commission's regulatory requirements. The staff will perform a complete licensing review of these applications using the Standard Revi.w Plan (NUREG-0800) and other appropriate Commission guidance. Satisfactory resolution of the vendor- or utility-specific items constitutes only one portion of the staff's review.

The rendor- or utility-specific items for the entire Requirements Document, provided by chapter or appendix with references to appropriate sections of the SER chapter or appendix given in parentheses, are listed below. The designators in front of each issue provide a unique identifier for each issue. The letter "E" or "P" indicates that the issue applies to evolutionary or passive plant designs, respectively. The first number designates the chapter in which it $i$ is identified. The letter that follows designates the appendix, if applicable. The letter $V$ designates that it is a vendor- or utility-specific item. The final number provides the sequential number assigned to it in Section 1.5 of each chapter or appendix.

\subsection{Vendor- or Utility-Specific Items Pertaining to the Requirements Document for Evolutionary Plant Designs}

The following is a list of vendor- or utility-specific items that are identified in the SER (Volume 2 of this report) on the Requirements Document for evolutionary plant designs.

Chapter 1 - Overall Requirements

E.1.V-1 scope of mitigation features (2.1 and 2.4)

E.1.1-2 implementation of design characteristics intended to enhance accident resistance (2.2)

E.1.1-3 bounding analysis by standard site design parameters (2.3.1) 
E.1.V-4 selection of initiating events and their frequency categorization (2.3.2)

E.1.V-5 acceptance criteria for transient and accident analysis (2.3.2)

E.1.V-6 anticipated transient without scram response analysis (2.3.2)

E.1.V-7 acceptability of analytical codes and methodologies for safety analys is $(2.5)$

E.1.V-8 60-year plant life $(3.3,4.8 .2,8.2$, and 11.3)

E.1.V-9 operation of PWR with a secured reactor coolant pump (3.5)

E.1.V-10 defense-in-depth analysis (3.5)

E.1.V-11 event response capability (3.5)

E.1.V-12 fuel burnup requirements (3.6)

E.1.V-13 extended operating life of control blades and control rod assemblies (3.6)

E.1.V-14 safety classification (4.3.1)

E.1.V-15 seismic qualification by experience (4.3.2 and 4.8.1)

E.1.V-16 non-seismic building structures (4.3.2 and 4.7.2)

E.1.V-17 structural design and construction codes (4.4 and 4.4.1)

E.1.V-18 elimination of operating-basis earthquake from design (4.4.3, 4.7.3, and Appendix B)

E.1.V-19 definition of support group (4.4.3)

E.1.V-20 use of Appendix $N$ of ASME Code, Section III (4.4.3 and 4.7.3)

E.1.V-21 analysis of vibratory loads with significant high-frequency input (4.4.3)

E.1.V-22 use of nonlinear analysis to account for gaps between pipes and piping supports $(4.4 .3)$

E.1.V-23 probabilistic approach for changing existing loads and/or loading combinations $(4.5 .1)$

E.1.V-24 recurrence interval for wind loadings (4.5.2)

E.1.V-25 maximum ground water level (4.5.2)

E.1.V-26 precipitation for roof design (4.5.2)

E.1.V-27 snow loading (4.5.2) 
E.1.V-28 detailed quantification of soil parameters (4.5.2)

E.1.V-29 minimum margin against liquefaction (4.5.2)

E.1.1-30 external hazards evaluation (4.5.2)

E.1.1-31 number of full-stress cycles (4.5.2 and 4.8.1)

E.1.1-32 site-specific SSE (4.5.2)

E.1.'1-33 power spectrum density function of the time history (4.5.2)

E.1.1-34 external impact hazards (4.5.2)

E.1.1/-35 design temperature (4.5.2)

E.1.1/-38 protection against surface vehicle bombs (4.5.3)

E.1.11-39 BWR safety/relief valve loads (4.5.4)

E.1.11-40 NUREG-1061 methodology and acceptance criteria for leak before break (4.5.5)

E.1.1/-41 hydrodynamic loads from safety/relief valves (4.5.5)

E.1.1'-42 suppression pool dynamic loads (4.5.5)

E.1.1'-43 design against internal-missile generation (4.5.5)

E.1.1'-44 design of concrete containment (4.6.1)

E.1.1-45 load combinations for seismic Category I buildings and structures (4.6.1)

E.1.V-46 design of seismic Category I steel structures (4.6.1)

E.1.V-47 combination of pipe rupture loads with seismic loads for seismic Category I structures (4.6.1 and 4.6.1)

E.1.V-48 combination of loss-of-coolant-accident and SSE loads (4.6.1)

E.1.V-49 load combinations for safety-related portions of the plant (4.6.2)

E.1.V-50 dynamic analysis techniques (4.7.2)

E.1.V-51 methodology for generating design response spectra or time histories (4.7.2)

E.1.V-52 structural damping values (4.7.2)

E.1.V-53 masonry walls in Category I buildings (4.7.2)

E.1.V-54 use of expansion anchor bolts - compliance with Office of Inspection and Enforcement Bullet in 79-02 (4.7.2 and 4.7.3) 
E.1.V-55 stability of shell-type structures under compression (4.7.2)

E.1.V-56 seismic evaluation and design of small-bore piping (4.7.3)

E.1.V-57 use of ASME Code Case N-411 (4.7.3)

E.1.V-58 use of ASME Code Cases N-411 and N-420 in same analys is (4.7.3)

E.1.V-59 construction of core support structures (4.7.3)

E.1.V-60 fatigue design curves (4.7.3)

E.1.V-61 use of IEEE $323(4.8 .2)$

E.1.V-62 environmental qualification of mechanical and electrical equipment (4.8.2)

E.1.V-63 use of zinc to reduce radiation fields $(5.2 .7)$

E.1.V-64 limits on nitrites, nitrates, and total halogens as chlorine $(5.2 .8)$

E.1.V-65 grinding controls for PWRs (5.3.1)

E.1.V-66 effect of fabrication processes on intergranular stress corrosion cracking (5.3.1 and 5.3.1)

E.1.V-67 hardness limits for stainless steel (5.3.1)

E.1.V-68 use of Alloy 600 and other alloys (5.3.1)

E.1.V-69 allowance for carbon and low-alloy-steel corrosion (5.3.1)

E.1.V-70 selection of seals, gaskets, and protective coatings (5.3.5)

E.1.V-71 aging of cable insulation and other electrical materials (5.3.6)

E.1.V-72 use of hydrogen water chemistry for the advanced BWR design (5.5.2)

E.1.V-73 PWR water chemistry (5.5.2)

E.1.V-74 submittal of operational reliability assurance program (0-RAP) (6)

E.1.V-75 organizational description for reliability assurance program (6.1)

E.1.V-76 analyses methods or models used in developing the reliability assurance program (6.2)

E.1.V-77 reliability data bases (6.2)

E.1.V-78 reliability, maintainability, and testability analyses (6.2)

E.1.V-79 apportionment of contributions of structures, systems, and components to core damage frequency (6.3) 
E.1 V-80 priority of safety in accident recovery (6.3)

E.1. V-81 relationship between safety and production availability (6.3)

E.1.V-82 effect of limitations on refueling duration on plant safety (6.3)

E.1.V-83 effect of planned outage duration on plant safety (6.3)

E.1.V-84 effect of major outage duration on plant safety (6.3)

E.1.V-85 inspection of construction activities ( 7 and 11.13)

E.1.V-86 quality assurance for non-safety-related facilities and systems (7)

E.1.V-87 installed operating-phase security system (7)

E.1.V-88 reliability of modular construction (7)

E.1.V-89 use of IEEE P1025 P1023-1988/D5 and EPRI-2360 for guidance regarding human factors engineering (8.2)

E.1.V-90 inspection and verification of security locks robotically (8.3)

E.1.V-91 quality assurance requirements for all equipment, structures, systems, facilities or software that have some safety importance or has one importance (9)

E.1.V-92 compliance of FDA/DC applications with Commission's regulations and guidance (10)

E.1.V-93 issue resolution for FDA/DC reviews (10)

E.1.V-94 inspections, tests, analyses, and acceptance criteria (10)

E.1.V-95 implementation of simplification objective (11.4)

E.1.V-96 implementation of standardization objective (11.5)

E.1.V-97 check valve testing methods (12.2.2)

E.1.1-98 full-flow testing of check valves (12.2.2)

E.1.1-99 qualification testing of active and nonactive motor-operated valves (MOVs) (12.2.2)

E.1.1/-100 technical concerns regarding MOVs (12.2.2)

E.1.1-101 leak rate testing for individual containment isolation valves (12.2.2)

E.1.1-102 instrumentation to determine net positive suction head during all modes of operation (12.2.3)

E.1.11-103 testing of pump flow rate (12.2.3) 
E.1.V-104 frequency and extent of disassembly and inspection of safetyrelated pumps (12.2.3)

Appendix A to Chapter 1 - PRA Key Assumptions and Groundrules

E.1A.V-1 use of PRA in design

E.1A.V-2 modeling of a PRA (1.6)

E.1A.V-3 shutdown and low-power events (1.6)

E.1A.V-4 external events $(1.6,3.3$, and 6.1$)$

E.1A.V-5 core damage frequency (1.7)

E.1A.V-6 uncertainty treatment (1.9 and 6.1)

E.1A.V-7 documentation of method of truncation of accident sequences ( 1.10 and 2.5)

E.1A.V-8 low-frequency accident initiators leading to core damage (2.2)

E.1A.V-9 mission time (2.10)

E.1A.V-10 failure rate for components (2.11)

E.1A.V-11 tornadoes and extreme winds (3.2)

E.1A.V-12 external river flooding (3.2)

E.1A.V-13 hurricanes and storm surges (3.2)

E.1A.V-14 tsunami (3.2)

E.1A.V-15 internal fires (3.2)

E.1A.V-16 site-specific external events

E.1A.V-17 internal flooding (3.2)

E.1A.V-18 seismic hazards analysis (3.3)

E.1A.V-19 core-damage-sequence binning (4.1)

E.1A.V-20 plant damage state definition (4.2)

E.1A.V-21 containment isolation assumptions and criteria (4.3)

E.1A.V-22 in-plant sequence assessment (4.5)

E.1A.V-23 containment event analysis (4.6)

E.1A.V-24 details of uncertainty analysis (4.6) 
E.1A.V-25 source term definition (4.7)

E.1A.V-26 event tree binning (4.8)

E.1A.V-27 risk measures related to containment performance (4.8)

E.1A.V-28 use of mean values for characterization of risk results (5.1)

E.1A.V-29 assessment of risk measures (5.2)

E.1A.V-30 calculation of offsite consequences (5.2)

E.1A.V-31 importance analysis for input to reliability assurance program (6.1)

E.1A.V-32 assessment of containment response (6.2)

E.1A.V-33 source term (6.3)

E.1A.V-34 scope and objective of human reliability analysis (HRA) (7.1)

E.1A.V-35 process and criteria to confirm adequacy of human reliability analys is (HRA) (7.2)

E.1A.V-36 impact of advanced technologies on HRA (7.3)

E.1A.V-37 function, task, timeline, and link analyses (7.3)

E.1A.V-38 generic data sources (7.3)

E.1A.V-39 performance shaping factors and their evaluation tools (7.3)

E.1A.V-40 quantification methods for HRA (7.3)

E.1A.V-41 loss of offsite power frequency (Annex A)

E.1A.V-42 site data (Annex B)

Appendix $B$ to Chapter 1 - Licensing and Regulatory Requirements and Guidance

E.1B.V-1 compliance of FDA/DC applications with Commission's regulations and guidance (1.3)

E.1B.V-2 issue resolution for FDA/DC reviews (1.3)

E.1B.V-3 elimination of missile provisions (2.1.2)

E.1B.V-4 dynamic seismic analysis of main steam piping and condenser (2.3.1.1 and Item II.E of Annex C)

E.1B.V-5 main steamline classification (2.3.1.1 and Item II.E of Annex C)

E.1B.V-6 seismic analysis and plant walkdown of turbine building (2.3.1.1 and Item II.E of Annex C) 
E.1B.V-7 plateout considerations for main steam piping and valves (2.3.1.2 and Item III.F of Annex $C$ )

E.1B.V-8 reactor pressure vessel level instrumentation system (2.4.1)

E.1B.V-9 source term (2.5.2.1, 2.5.2.2, Item I.B of Annex A, and Item I.A of Annex C)

E.1B.V-10 compliance with Branch Technical Position MTEB 6.1 (2.5.2.2)

E.1B.V-11 fission product cleanup analys is (2.5.2.2)

E.1B.V-12 deletion of charcoal adsorbers (2.5.2.2)

E.1B.V-13 dedicated containment vent penetration (2.5.3 and Item I.K of Annex C)

E.1B.V-14 decoupling of operating-basis earthquake (OBE) from safe shutdown earthquake (SSE) in seismic design of structures (Generic Safety Issue $A-40)(3.2 .7)$

E.1B.V-15 deletion of OBE damping values in seismic design of structures (Generic Safety Issue A-40) (3.2.7)

E.1B.V-16 use of algebraic sum method for modal combination of high-frequency modes for vibratory loads (Generic Safety Issue A-40) (3.2.7)

E.1B.V-17 use of spectral peak shifting techniques in lieu of spectral broadening (Generic Safety Issue A-40) (3.2.7)

E.1B.V-18 plant-specific design and arrangement of control systems (Generic Safety Issue A-47) (3.2.9)

E.1B.V-19 conformance to 10 CFR 50.34(f) hydrogen control requirements (Generic Safety Issues A-48 and 121) (3.2.10 and 3.2.46)

E.1B.V-20 reliability of emergency diesel generators (Generic Safety Issue $B-56)(3.2 .14)$

E.1B.V-21 resolution of Generic Safety Issues 2 and 110 (3.2.18 and 3.2.42)

E.1B.V-22 resolution of Generic Safety Issue 15 (3.2.19)

E.1B.V-23 independent reactor coolant pump seal cooling during station blackout (Generic Safety Issue 23) (3.2.20)

E.1B.V-24 resolution of Generic Safety Issue 24 (3.2.21)

E.1B.V-25 design details on threaded fasteners (Generic Safety Issue 29) (3.2.22)

E.1B.V-26 reduction of biofouling in open-cycle service water and component cooling water systems (Generic Safety Issue 51) (3.2.23) 
E.111.V-27 resolution of Generic Safety Issue 57 (3.2.24)

E.1li.V-28 resolution of Generic Safety Issue 73 (3.2.26)

E.1Ei.V-29 equipment classification and vendor interface for reactor trip system components (Generic Safety Issue 75) (3.2.27)

E.1E.V-30 2-week requirement for corrective maintenance (Generic Safety Issue 75$)(3.2 .27)$

E.1E.V-31 preventive maintenance and surveillance program for reactor trip breakers (Generic Safety Issue 75) (3.2.27)

E.1E.V-32 resolution of Generic Safety Issue 76 (3.2.28)

E.1E.V-33 cooldown rate in natural convection cooldown analysis (Generic Safety Issue 79) (3.2.29)

E.1E.V-34 low-density storage racks in spent fuel pool for most recently discharged fuel (Generic Safety Issue 82) (3.2.30)

E.1B.V-35 plant-specific design and arrangement for control room heating, ventilating, and air conditioning (HVAC) system (Generic Safety Issue 83) (3.2.31)

E.1B.V-36 design of emergency filter units (Generic Safety Issue 83) (3.2.31)

E.1B.V-37 design details for control room capacity following a design-basis accident (Generic Safety Issue 83) (3.2.31)

E.1B.V-38 design details for control room HVAC systems in the smoke removal mode (Generic Safety Issue 83) (3.2.31)

E.1B.V-39 resolution of Generic Safety Issue 87 (3.2.33)

E.1B.V-40 adequacy of low-temperature overpressure protection design (Generic Safety Issue 94) (3.2.34)

E.1B.V-41 adequacy of BWR water level redundancy (Generic Safety Issue 101) (3.2.37)

E.1B.V-42 interfacing system design details (Generic Safety Issue 105) (3.2.39)

E.1B.V-43 inservice testing programs and technical specifications for appropriate pressure isolation valves (Generic Safety Issue 105) (3.2.39)

E.1B.V-44 resolution of Generic Safety Issue 106 (3.2.40)

E.1B V-45 environmental qualification and inservice inspection and testing of large-bore hydraulic snubbers (Generic Safety Issue 113) (3.2.43) 
E.1B.V-46 use of prestressed concrete containments (Generic Safety Issue 118) (3.2.44)

E.1B.V-47 reliability, operability, and on-line testability of protection system final actuation contacts (Generic Safety Issue 120) (3.2.45)

E.1B.V-48 operator training program and emergency operating procedures related to initiating feed-and-bleed cooling (Generic Safety Issue 122.2) (3.2.50)

E.1B.V-49 auxiliary feedwater analyses (Generic Safety Issue 124) (3.2.52)

E.1B.V-50 operational aspects of electrical power reliability (Generic Safety Issue 128) (3.2.56)

E.1B.V-51 resolution of Generic Safety Issue 130 (3.2.57)

E.1B.V-52 resolution of Generic Safety Issue 132 (3.2.58)

E.1B.V-53 resolution of Generic Safety Issue 135 (3.2.59)

E.1B.V-54 resolution of Generic Safety Issue 142 (3.2.60)

E.1B.V-55 resolution of Generic Safety Issue 143 (3.2.61)

E.1B.V-56 resolution of Generic Safety Issue 151 (3.2.62)

E.1B.V-57 assessment of safety service water system failure modes and contributions to core damage frequency and identification of dominant accident sequences (Generic Safety Issue 153 (3.2.63)

E.1B.V-58 resolution of Generic Safety Issue HF 4.4 (3.2.64)

E.1B.V-59 resolution of Generic Safety Issue HF 5.1 (3.2.65)

E.1B.V-60 resolution of Generic Safety Issue HF $5.2(3.2 .66)$

Chapter 2 - Power Generation Systems

E.2.V-1 safety valve design (3.4)

E.2.V-2 attachment loads for safety and relief valves (3.4)

E.2.V-3 side stream condensate polisher (4.3)

E.2.V-4 condensate makeup system raw water pretreatment (6.4)

Chapter 3 - Reactor Coolant System and Reactor Non-Safety Systems

E.3.V-1 power supplies for power-operated relief valves (3.3)

E.3.V-2 pressurizer heater power source control design (3.4)

E.3.V-3 chemical and volume control system design (6.2) 


\section{Chapter 4 - Reactor Systems}

E.4.V-1 reactor pressure vessel fatigue design criteria (2.3.2)

E.4.V-2 BWR thermal-hydraulic stability performance during an anticipated transient without scram (4.2)

E.4.V-3 BWR nuclear and thermal-hydraulic design for extended cycle operation (4.2)

E.4.V-4 effect of electric protective assemblies on reactor protection system power supply requirements (5.3)

E.4.V-5 PWR thermal-hydraulic stability and xenon stability characteristics (7.2)

E.4.'V-6 PWR fuel design for load-following capability (7.2)

E.4.' V-7 60-year service life for control rod drive mechanisms (8.2)

\section{Chapter 5 - Engineered Safety Systems}

E.5.'1-1 containment performance criteria for severe accidents (2.1)

E.5.1-2 metal-water reaction and hydrogen generation and control during a severe accident (2.3 and 6.5.1)

E.5.1/-3 fire protection (2.5)

E.5.1/-4 diesel generator start time (3.2)

E.5.1-5 detailed LOCA analysis concerning core spray for BWRs (4.1)

E.5.1-6 safety classification of containment spray system (4.4 and 7.2)

E.5.11-7 suppression pool bypass leakage (4.5 and 7.2)

E.5.11-8 suppression pool temperature-monitoring system (4.6)

E.5.11-9 intersystem LOCA (5.2)

E.5.11-10 operation of RHR system with reduced reactor coolant system inventory (Generic Letter 87-12) (5.2)

E.5.11-11 shutdown risk (5.2)

E.5.11-12 feed-and-bleed capability (5.4)

E.5.1-13 safety depressurization and vent system $(5.4,5.5$, and 6.6.5)

E.5.1-14 use of remote manual valves on essential lines that are not part of the engineered safety systems (6.2)

E.5.1'-15 Type C leak testing (6.2) 
E.5.V-16 containment integrated leak rate testing (6.3.1)

E.5.V-17 Type A leak testing (6.3.1)

E.5.V-18 Type B testing of air locks (6.3.2)

E.5.V-19 use of water in Type $C$ containment leak rate testing (6.3.3)

E.5.V-20 Type $C$ containment valve leak rate testing interval (6.3.3)

E.5.V-21 control systems for radiolytically generated hydrogen (6.5.2)

E.5.V-22 design criteria for igniter system (6.5.3)

E.5.V-23 evaluation of igniter system (6.5.3)

E.5.V-24 method for determining load collapse of containment (6.6.1)

E.5.V-25 concrete containment analysis (6.6.1)

E.5.V-26 containment overpressure protection (6.6.3)

E.5.V-27 functionability of fission product control systems during a severe accident (6.6.4)

E.5.V-28 equipment survivability criteria for severe accidents (6.6.6)

E.5.V-29 accident management $\mathrm{plan}(6.6 .8)$

E.5.V-30 dynamic effects of pipe breaks during severe accidents (7.2)

E.5.V-31 main steam isolation valve leakage rate (7.2)

E.5.V-32 suppression pool design features (7.3)

E.5.V-33 containment leak rate (8.1)

E.5.V-34 postaccident $\mathrm{pH}$ control (8.2 and Appendix B to Chapter 1)

Chapter 6 - Building Design and Arrangement

E.6.V-1 thermal growth of steel members (2.1)

E.6.V-2 inspectability of structural walls (2.1)

E.6.V-3 deviations from National Fire Protection Association codes and standards (2.3)

E.6.V-4 qualification criteria for fire barriers (2.3)

E.6.V-5 fire protection features in the heating, ventilation, and air conditioning (HVAC) design criteria (2.3) 
E.6.'1-6 compliance with the requirements of Three Mile Island (TMI) Action Plan Item II.B.2 (2.3)

E.6.1-7 details of shielding design and shielding computer codes $(2.3,2.4$, and 4.2 .8 )

E.6.11-8 effect of site-specific topography on standard overall site arrangement (3.1)

E.6.11-9 flooding protection design requirements (3.3.1)

E.6.11-10 alternative seismic restraint devices $(4.2 .3)$

E.6.1-11 piping and instrument line support design (4.2.4)

E.6.1'-12 description of airborne radioactive material sources $(4.2 .5)$

E.6.1'-13 potential high-radiation areas, shielding, and measures for minimizing exposure (4.2.8 and 4.2.9)

E.6.1'-14 review of coatings against SRP Section $6.1 .2(4.2 .10$ and 4.3.2)

E.6.V-15 use of epoxy-coated reinforcing bars at intake structures (4.2.11)

E.6.V-16 features to ensure $\mathrm{H} 2$ concentrations do not exceed detenation levels $(4.3 .2)$

E.6-V-17 elimination of diagonal rebar in reinforced-concrete containment $(4.3 .2)$

E.6-V-18 floor size for reactor vessel cavity/drywell (4.3.2)

E.6-V-19 design features that preclude potentially lethal radiation levels (4.3.3)

E.6.V-20 containment access control (4.3.3 and 4.3.4)

E.6.V-21 details of design of BWR reactor building (4.4.2)

E.6.V-22 details of design of PWR auxiliary building (4.4.3)

E.6.V-23 turbine-generator building seismic design loading (4.5.2)

E.6.V.24 details of design of BWR turbine-generator building (4.5.4)

E.6.V-25 details of design of radwaste facility (4.6.3)

E.6.V-26 details of emergency onsite power supply facility (4.6.4)

E.6.V-27 details of HVAC design for control complex (4.6.5)

E.6.V-28 details of design of technical support center (4.6.6) 
Chapter 7 - Fueling and Refueling Systems

E.7.V-1 quality group classification of components for new and spent fuel storage racks $(3.2 .1)$

E.7.V-2 radiological consequences of fuel handling accident (3.2.2)

E.7.V-3 protection against tampering during refueling activities (3.2.4)

E.7.V-4 design of the overhead bridge crane (6.1.2)

E.7.V-5 radiological consequences of fuel cask drop accident (6.5)

E.7.V-6 design of the fuel handling system (7.1.2)

E.7.V-7 reactor disassembly and servicing equipment for BWRs (7.5)

Chapter 8 - Plant Cooling Water Systems

E.8.V-1 pump minimum flow line or recirculation line design (3.2)

E.8.V-2 reduction of surveillance testing (3.2)

E.8.V-3 availability of emergency power supply for the fuel pool cooling and cleanup system following a design-basis accident (9)

Chapter 9 - Site Support Systems

E.9.V-1 fire protection review (3)

E.9.V-2 fire hazard analysis (3.2.2)

E.9.V-3 smoke removal capability (3.3.1)

E.9.V-4 security hardware on fire doors (3.3.1)

E.9.V-5 separation of redundant shutdown equipment in the containment (3.3.1)

E.9.V-6 control room cable fires (3.4.9)

E.9.V-7 security area devitalized during unit shutdown (5.1)

E.9.V-8 operability of safety-related systems in areas with shared HVAC systems (8.2.1)

E.9.V-9 criteria for design of HVAC ductwork (8.2.1)

E.9.V-10 HVAC design for PWR auxiliary building (8.2.5 and 8.4.4)

E.9.V-11 HVAC design for miscellaneous areas (8.2.6)

E.9.V-12 charcoal filters in containment purge system (Branch Technical Position CSB 6-4, NUREG-0800) (8.4.2) 
E.9.1-13 design, equipment, and instrumentation for laboratories (9)

E.9.1/-14 determination of airborne iodine concentration during an accident (Item III.D.3.3 of NUREG-0737) (9)

Chap:er 10 - Man-Machine Interface Systems

E.10.V-1 software protection (2.3)

E.10.V-2 level of automation (2.3)

E.10.V-3 review of equipment used for displays to the operator (2.3)

E.10.V-4 methods to ensure operator alertness (2.3)

E.10.V-5 additional criteria for developing technology (2.3)

E.10.V-6 independence of verification and validation review teams (3.1.2)

E.10.V-7 use of commercial compilers for software used in safety systems (3.1.2)

E.10.V-8 dedication of commercial-grade software (3.1.2 and 6.1.2)

E.10.V-9 use of commercial-grade equipment (3.1.2)

E.10.V-10 complexity of M-MIS (3.1.3)

E.10.V-11 clarification of requirements for analysis and validation testing of M-MIS (3.1.3)

E.10.V-12 use of unproven technology (3.2.2)

E.10.V-13 operator aids (3.4.5)

E.10.V-14 quantitative reliability criteria (3.5)

E.10.V-15 establishment and use of reliability and availability estimates (3.5)

E.10.V-16 selection of equipment failure modes (3.5.1 and 6.2.7)

E.10.V-17 maintenance frequency (3.5.2)

E.10.V-18 reliability analysis (3.5.4)

E.10.V-19 component reliability of M-MIS (3.5.4)

E.10.V-20 overall reliability of M-MIS (3.5.4)

E.10.V-21 minimum tests for continuous on-line testing (3.6.1)

E.10.V-22 automatic reconfiguration after failure detection (3.6.4) 
E.10.V-23 surveillance period of automatic testing features (3.6.8)

E.10.V-24 automatic bypass initiation (3.6.10, 3.6.13, and 3.6.14)

E.10.V-25 module software concerns (3.7.4)

E.10.V-26 bypass and test lockouts during on-line repairs (3.7.6)

E.10.V-27 guidance on use of simulators and mockups (4.1.3)

E.10.V-28 vulnerability of power supplies for alarm systems (4.3.1)

E.10.V-29 alarm suppression techniques (4.3.3)

E.10.V-30 guidance on criteria to establish priorities (4.3.4)

E.10.V-31 guidance on the maximum number of alarms (4.3.4)

E.10.V-32 guidance on frequency allocation plan (4.6)

E.10.V-33 guidance on interference between communication systems and M-MIS equipment (4.6)

E.10.V-34 unauthorized access to equipment in remote shutdown stations $(4.9 .1)$

E.10.V-35 guidance on inadvertent actuation of controls at local control stations (4.9.2)

E.10.V-36 design of emergency operations facility (4.9.4)

E.10.V-37 modification of security boundaries during an emergency (4.9.4)

E.10.V-38 data storage methods (4.9.4)

E.10.V-39 compliance of perimeter intrusion alarm system with 10 CFR 73.55(h) (5.2.1)

E.10.V-40 guidance on data system characteristics (5.2.2)

E.10.V-41 signal transport delay (5.2.5)

E.10-V-42 acceptability of digital-to-analog and analog-to-digital convertors (5.7)

E.10.V-43 software requirement specification (6.1.2)

E.10.V-44 verification of software $(6.1 .2)$

E.10.V-45 documentation of testing and verification of commercially available software (6.1.2)

E.10.V-46 acceptance testing of commercially available software (6.1.2) 
E.10.V-47 configuration control of software purchased through software clearinghouses (6.1.2)

E.10.V-48 guidance on convolution of software structure (6.1.3)

E.10.V-49 behavior of commercial software when assumptions are violated $(6.1 .3)$

E.10.V-50 guidance on memory protection (6.1.3)

E.10.V-51 separation of databases for redundant safety-related devices (6.1.3)

E.10.V-52 definition of reasonable testing and sufficient degree of confidence $(6.1 .5)$

E.10.V-53 specification of the level of diversity in safety systems (6.1.6, 6.2.3)

E.10.V-54 specific methods used to meet the requirement for diversity (6.1.6)

E.10.V-55 elimination of EMI (6.2.2)

E.10.y-56 compatibility between M-MIS equipment and its external power supply systems (6.2.2)

E.10.V-57 signal validation methodology (6.2.2)

E.10.V-58 capacitance-type pressure sensors (6.2.5)

E.10.V-59 minimal acceptance review criteria for isolation device (6.2.6)

E.10.V-60 EMI/RFI considerations for wiring shields (6.2.9)

E.10.V-61 restoration state of control system components after loss of power (6.3.2)

E.10.V-62 setting resolution for control parameters (6.3.3)

E.1).V-63 requirements for signal reconstruction (6.3.3)

E.1).V-64 use of interrupts (6.3.3)

E.1J.V-65 continuous self-testing of actuation logic (8.3.2)

E.1).V-66 radiation monitor placement, calibration frequency, and emergency power provisions $(10.2: 1)$

E.1J.V-67 compliance with Item II.F.1.3 of NUREG-0737 (10.2.1)

E.1J.V-68 criteria for airborne radioactivity monitors (10.2.1) 
E.10.V-69 14-day maintenance criteria for M-MIS for reactor protection system, plant control system, and plant information and monitoring systems (GSI 75) (Appendix B)

E.10.V-70 procedures to assess unscheduled reactor shutdowns (GSI 75) (Appendix B)

E.10.V-71 safety implication of instrumentation and control systems (USI A-47, GSI 76) (Appendix B)

E.10.V-72 inclusion of computer specialist on design and review teams (3.1 of Appendix D)

E.10.V-73 establishment of Q-1ist and associated equipment list (GSI 75) (Appendix B)

E.10.V-74 handling of vendor interface (GSI 75) (Appendix B)

E.10.V-75 evaluate neutron monitoring system M-MIS (7.4)

E.10.V-76 reliable operation of reactor trip breaker (GSI 75) (Appendix B)

E.10.V-77 design of BWR water level instrumentation (GSI 101) (Appendix B)

E.10.V-78 operator training and emergency operating procedures concerning feed-and-bleed operations (GSI 122.2) (Appendix B)

E.10.V-79 human factors organization (3.1 of Appendix D)

E.10.V-80 acoustical environments in operating control areas (3.7.6 of Appendix D)

E.10.V-81 design reference documents include IEEE P1023/D5 (3.7.6 of Appendix D)

Chapter 11 - Electric Power Systems

E.11.V-1 environmental qualification test criteria for electrical power system (2.2)

E.11.V-2 safety classification of loads (2.2.1)

E.11.V-3 minimization of Class $1 \mathrm{E}$ components (2.2.4)

E.11.V-4 instrumentation and controls for electric motors (2.2.5)

E.11.V-5 compliance with NFPA Codes and Standards (2.2.6)

E.11.V-6 integrity of electrical cable penetration seals during a fire (2.2.6)

E.11.V-7 integrity of bus duct penetrations during a fire (2.2.6)

E.11.V-8 review of IEEE standards not endorsed by regulatory guides (2.2.7) 
E.11,V-9 review of the actual setpoint criteria used for sizing thermal overloads (2.2.9)

E.11.V-10 limitation of total voltage distortion to 3 percent (4.2.4)

E.11.V-11 effects of electrical faults on the coastdown capability of the reactor coolant pumps and reactor internal pumps (4.2.5)

E.11 V-12 use of combustion turbine generator as alternate power source during shutdown (5.2.1)

E.11.V-13 continuous rating versus short-term rating for sizing the combustion turbine generator (5.2.3)

E.11.V-14 inclusion of the pressurizer heaters in the diesel generator power analysis (5.2.4)

E.11.V-15 continuous rating of the diesel generators to include emergency lighting (5.2.4)

E.11.V-16 capability of the diesel generators to power safety buses in a protected bus configuration (5.2.5)

E.11.V-17 emergency diesel engine starting system (5.2.6)

E.11.V-18 emergency diesel engine fuel oil storage and transfer system (5.2.6)

E.11.V-19 allowed outage time for load center (6.2)

E.11.V-20 impact of loss of ac or dc bus on single-failure protection in safety-related systems $(7.2 .1)$

E.11.V-21 outage time for dc safety buses in a BWR plant design (7.2.2)

E.11.V-22 common backup ac power sources for safety-related uninterruptible power supplies $(7.2 .4)$

E.11.V-23 design of the continuous ac lighting in safety-related areas and access routes outside the main control room (8.2.1 and 8.2.2)

E.11.V-24 method of integrating the emergency lighting system with the normal lighting in the main control room $(8.2 .3)$

E.11.V-25 acceptability of lighting system for closed-circuit television system (8.2.4)

Chapter 12 - Radioactive Waste Processing Systems

E.12.V-1 inputs and releases from the radioactive waste processing systems (2.2.1)

E.12.V-2 use of demonstrated technology (2.2.1) 
E.12.V-3 offsite dose calculation manual (2.2.1)

E.12.V-4 fue1 source term parameters for design of radioactive waste processing systems (2.2.2)

E.12.V-5 estimate of personnel radiation exposure (2.2.4)

E.12.V-6 control, monitoring and sampling of liquid and radioactive waste processing and effluent streams (2.2.9)

E.12.V-7 interface between BWR HVAC systems and GRWP systems (3.3.2)

E.12.V-8 use of HEPA filters downstream of charcoal adsorbers (3.3.3)

E.12.V-9 potentially explosive mixtures of hydrogen and oxygen (3.3.4)

E.12.V-10 piping layout and design and operating procedures for filters and ion exchangers in liquid radioactive waste processing systems (4.2)

E.12.V-11 shipping container design (5.5)

Chapter 13 - Main Turbine-Generator System

E.13.V-1 60-year design life for major components of the main turbinegenerator (2.2)

E.13.V-2 use of seismic experience data base for seismic qualification (3.1.1)

E.13.V-3 performance and safety requirements for main turbine (3.1.3)

E.13.V-4 turbine maintenance program

E.13.V-5 effect of other duty cycles on long-term integrity of the turbine (3.1.4)

E.13.V-6 facture toughness properties of turbine casing material (3.1.4)

E.13.V-7 part-machining inspection of one-piece rotor (3.1.5)

E.13.V-8 need for prototype testing of new or significantly changed designs (3.1.6 and 4.1.1)

E.13.V-9 adequacy of turbine control system (3.3)

E.13.V-10 inservice inspection intervals for main stop and control valves and reheat stop and intercept valves (3.3)

E.13.V-11 seal clearances of $\mathrm{gland}$ seal system (3.4) 


\subsection{Vendor- or Utility-Specific Items Pertaining to the Requirements Document for Passive Plant Designs}

The following is a list of vendor-or utility-specific items that were identified in the DSER on the Requirements Document for passive plant designs.

\section{Chapter 1 - Overall Requirements}

P.1.V-1 implementation of design characteristics intended to enhance accident resistance (2.2)

P.1.'V-2 bounding analysis by standard site design parameters (2.3.1)

P.1.1-3 selection of initiating events and their frequency categorization (2.3.2)

P.1.1-4 acceptance criteria for transient and accident analysis (2.3.2)

P.1.1-5 passive plant anticipated transient without scram response analysis $(2.3 .2)$

P.1.1/6 operator actions 72 hours after accident (2.3.2)

P.1.1/-7 use of 72-hour design basis (2.3.2)

P.1.11-8 technical basis for severe-accident management program and emergency operating procedures guidelines (2.3.4)

P.1.11-9 acceptability of analytical codes and methodologies for safety analys is (2.5)

P.1.11-10 defense-in-depth analysis (2.5 and 3.5)

P.1.1-11 60-year plant life $(3.3,4.8 .2,8.2$ and 11.3)

P.1.1'-12 operation of PWR with a secured reactor coolant pump (3.5)

P.1.1-13 fuel burnup requirements (3.6)

P.1.1'-14 extended operating life of control blades and control rod assemblies (3.6)

P.1.1'-15 safety classification (4.3.1)

P.1.V-16 seismic qualification by experience (4.3.2 and 4.8.1)

P.1.V-17 non-seismic building structures $(4.3 .2 .3$ and 4.7 .2 .10$)$

P.1.V-18 structural design and construction codes (4.4 and 4.4.1)

P.1.V-19 elimination of operating-basis earthquake from design (4.4.3, 4.7.3, and Appendix B) 
P.1.V-20 definition of support group (4.4.3)

P.1.V-21 use of Appendix $N$ of ASME Code, Section III (4.4.3 and 4.7.3)

P.1.V-22 analysis of vibratory loads with significant high-frequency input $(4.4 .3)$

P.1.V-23 use of nonlinear analys is to account for gaps between pipes and piping supports $(4.4 .3)$

P.1.V-24 probabilistic approach for changing existing loads and/or loading combinations (4.5.1)

P.1.V-25 recurrence interval for wind loadings $(4,5.2 .1)$

P.1.V-26 maximum ground water level (4.5.2.2)

P.1.V-27 precipitation for roof design (4.5.2.2)

P.1.V-28 snow loading (4.5.2.2)

P.1.V-29 detailed quantification of soil parameters (4.5.2.3)

P.1.V-30 minimum margin against liquefaction (4.5.2.3)

P.1.V-31 external hazards evaluation (4.5.2.3)

P.1.V-32 number of full-stress cycles (4.5.2.4 and 4.8.1)

P.1.V-33 site-specific safe shutdown earthquake (SSE) $(4.5 .2 .4)$

P.1.V-34 power spectrum density function of the time history $(4.5 .2 .4)$

P.1.V-35 design temperature $(4 \cdot 5 \cdot 2.7)$

P.1.V-36 protection against surface vehicle bombs (4.5.3)

P.1.V-37 design against internal-missile generation (4.5.5)

P.1.V-38 design of concrete containment (4.6.1.1)

P.1.V-39 load combinations for Category I buildings and structures (4.6.1.2)

P.1.V-40 design of Category I steel structures (4.6.1.2)

P.1.V-41 combination of pipe rupture loads with seismic loads for seismic Category I structures (4.6.1.3 and 4.6.1.4)

P.1.V-42 combination of LOCA and SSE loads (4.6.1.7)

P.1.V-43 load combinations for safety-related portions of the plant (4.6.2)

P.1.V-44 dynamic analysis techniques (4.7.2.3) 
P.1.1'-45 methodology for generating design spectra or time histories $(4.7 .2 .5)$

P.1.1'-46 structural damping values $(4.7 .2 .6)$

P.1.1'-47 masonry walls in Category I buildings (4.7.2.7)

P.1.1'48 use of expansion anchor bolts - compliance with Office of Inspection and Enforcement Bullet in 79-02 (4.7.2.8 and 4.7.3)

P.1.1-49 stability of shell-type structures under compression (4.7.2.9)

P.1.1-50 use of ASME Code Cases $\mathrm{N}-411$ and $\mathrm{N}-420$ in same analys is (4.7.3)

P.1.V'-51 use of ASME Code Case N-411 (4.7.3)

P.1.1-52 construction of core support structures (4.7.3)

P.1.'-53 design fatigue curves (4.7.3)

P.1.1'-54 use of zinc to reduce radiation fields (5.2.7)

P.1.I'-55 grinding controls for PWRs (5.3.1.1)

P.1.1'-56 use of A1loy $600(5.3 .1 .3)$

P.1.'-57 effect of fabrication processes on intergranular stress corrosion cracking (5.3.1.8)

P.1.1'-58 selection of seal, gaskets, and protective coatings (5.3.5)

P.1.1'59 aging of cable insulations and other electrical materials (5.3.6)

P.1.V'-60 use of hydrogen water chemistry for the advanced BWR design (5.5.2)

P.1.1'-61 plant-specific reliability assurance program (6.5)

P.1.1'-62 inspection of construction activities ( 7 and 11.13)

P.1.1'-63 installed operating-phase security system (7)

P.1.1'-64 reliability of modular construction (7)

P.1.1'-65 inspection and verification of security locks robotically (8.3)

P.1.1-66 compliance of FDA/DC applications with Commission's regulations and guidance (10)

P.1.V'-67 issue resolution for FDA/DC reviews (10)

P.1.1'-68 inspections, tests, analyses, and acceptance criteria (10)

P.1.1'-69 implementation of simplification objective (11.4) 
P.I.V-70 implementation of standardization objective (11.5)

P.1.V-71 inservice testing requirements for the essential non-safety-related components $(12.2 .1$ and 12.2 .3$)$

P.1.V-72 quarterly testing of pumps and valves $(12.2 .2)$

P.1.V-73 check valve testing methods (12.2.2)

P.1.V-74 full-flow testing of check valves (12.2.2)

P.1.V-75 provisions to test hydraulically and pneumatically operated valves under design-basis differential pressure and flow (12.2.2)

P.1.V-76 qualification testing of active and non-active motor-operated valves (MOVs) $(12.2 .2)$

P.1.V-77 technical concerns regarding MOVs (12.2.2)

P.1.V-78 leak rate testing for individual containment isolation valve $(12.2 .2)$

P.1.V-79 frequency and extent of disassembly and inspection of safety-related pumps $(12.2 .3)$

Appendix A to Chapter 1 - PRA Key Assumptions and Groundrules

P.1A.V-1 long-term decay heat removal in the PRA (1.6)

P.1A.V-2 justification of mission items and success criteria (2.10)

P.1A.V-3 reliability data (2.11)

P.1A.V-4 review of core-damage-sequence binning (4.1)

P.IA.V-5 review of actual groupings of the accident sequences into plant damage states $(4.2)$

P.1A.V-6 review of the evaluation of containment leakage paths (4.3)

P.1A.V-7 computer codes for in-plant sequence assessment (4.4)

P.1A.V-8 verification that the reference site parameters identified in Annex $B$ are consistent with revised 10 CFR Part $100(5.2)$

P.1A.V-9 differences in computer codes used for calculating offsite consequences (5.2)

P.1A.V-10 source terms for representative accident sequences bounded by the physically based source term $(6.3)$ 
Appendix B to Chapter 1 - Licensing and Regulatory Requirements and Guidance

P.1B.V-1 compliance of FDA/DC applications with Commission's

regulations and guidance (1.2)

P.13.V-2 issue resolution for FDA/DC reviews (1.2)

P.13.V-3 dynamic seismic analysis of main steam piping and condenser (2.3.1 and Item II.E of Annex A)

P.13.V-4 main steamline piping classification (2.3.1 and Item II.E of Annex A)

P.13.V-5 seismic analysis of turbine building (2.3.1 and Item II.E of Annex A)

P.13.V-6 plateout considerations for main steam piping and valves (2.3.1 and Item III.F of Annex A)

P.13.V-7 reactor vessel level instrumentation system (2.4.1)

P.13.V-8 dedicated containment vent penetration (2.5.4 and Item I.K of Annex A)

P.1B.V-9 fission product leakage control (2.5.2 and Item III.F of Annex A)

P.1B.V-10 fission product cleanup system (2.5.2 and Item III.F of Annex A)

P.1B.V-11 automatic emergency core cooling system switch to recirculation (Generic Safety Issue 24) (3.2.11)

P.1B.V-12 bolting degradation or failure (Generic Safety Issue 29) (3.2.12)

P.1H.V-13 detached thermal sleeves (Generic Safety Issue 73) (3.2.15)

P.1E.V-14 failure of high-pressure coolant injection steamline without isolation (Generic Safety Issue 87) (3.2.20)

P.1E.V-15 adequate leak test requirements for pressure isolation valves in inservice testing programs and technical specifications (3.2.22)

P.1Ei.V-16 identification and design of interfacing systems (3.2.22)

P.1E.V-17 implementation of procedures for electrical power reliability $(3.2 .27)$

P.1E.V-18 leakage through electrical isolators in instrumentation circuits (Generic Safety Issue 142) (3.2.29)

P.IE.V-19 availability of chilled water systems and room cooling (Generic Safety Issue 143) (3.2.30)

P.1E.V-20 reliability of recirculation pump trip during an anticipated transient without seram (Generic Safety Issue 151) (3.2.31) 
P.1B.V-21 loss of emergency service water system (Generic Safety Issue
153) (3.2.32)

P.1B.V-22 spectral peak shifting (3.3.1)

Chapter 2 - Power Generation Systems

P.2.V-1 turbine bypass system flow capacity (3.2)

P.2.V-2 attachment loads for PWR safety and relief valves (3.4)

P.2.V-3 design adequacy of side stream polisher (4.3)

Chapter 3 - Reactor Coolant System and Reactor Non-Safety Auxil iary Systems

P.3.V-1 vent and drain design (2.1.2)

P.3.V-2 reactor coolant interface systems design $(2.1 .7,3.1$, and 5.1)

P.3.V-3 specific performance requirements and acceptance criteria for active non-safety auxiliary systems (2.2, 6, and 8)

P.3.V-4 safety analyses of the abnormal conditions associated with loss of a feed pump or load rejection (3.2)

P.3.V-5 acceptability of operation with reactor coolant pump(s) out of service (3.2)

P.3.V-6 low-temperature overpressure protection system design details (3.3)

P.3.V-7 design analyses to confirm the capability and reliability of the passive decay heat removal system (3.4)

P.3.V-8 specific design requirements for reactor vessel level instrumentation system (3.5)

P.3.V-9 design details of the man-machine interface system for steam generator water level control (4.5)

P.3.V-10 design details to mitigate excessive leakage of'main steam isolation values (5.4)

P.3.V-11 design details for automatic reactor vessel overfill protection (5.5)

P.3.V-12 design details for PWR auxiliary systems, including chemical and volume control system, against criterion in Standard Review Plan Section 9.3.4 (6)

P.3.V-13 design details for reactor shutdown cooling pump seals (9)

P.3.V-14 adequate vendor assessment of shutdown and low-power-operation risk (9) 
Chapt:er 4 - Reactor Systems

P.4.1/-1 boration of water for fuel handling and storage (2.2.8)

P.4.1-2 fuel assembly reconstitution (2.3.3)

P.4.1'-3 condensation carryunder limitation (3.2)

P.4.1'-4 experimental data for divided-chimney design (3.2 and 4.2.1)

P.4.1'-5 BWR stability (2.2.4 and 4.2.1)

P.4.1'-6 decay ratio limits and analysis methods and procedures (4.2.1)

P.4.1-7 LOCA analysis methodology (4.2.1 and 7.2.1)

P.4.1'-8 load-following and maneuvering capability (4.2.1 and 7.2.1)

P.4.1-9 methodology to achieve BWR stability (4.2.1)

P.4.1-10 fuel burnup requirements (4.2.2 and 7.2 .2$)$

P.4.V-11 two-cycle fuel channel lifetime (4.2.4)

P.4.V-12 control rod assembly lifetime (4.2.6 and 7.2.3)

P.4.V-13 control rod scram time (5.2)

P.4.V-14 control rod assembly malfunctions in BWR accident analyses (5.2)

P.4.V-15 protection of scram pilot solenoid valves (5.3)

P.4.V-16 thermal shield removal (6.3)

P.4.V-17 reactor pressure vessel level instrumentation (6.3)

P.4.V-18 negative moderator temperature coefficient limit (7.3)

P.4.V-19 fuel rod bow penalties (7.3)

P.4.V-20 control rod drive mechanism lifetime (8.2)

\section{Chapter 5 - Engineered Safety Systems}

P.5.V-1 decontamination factor for containment system (2.1.7)

P.5.V-2 challenge from inadvertent opening of the DPS (2.2)

P.5.V-3 safety-grade provisions for the fire protection system (2.3)

P.5.V-4 LOCA calculations justifying removal of core spray system (4.1)

P.5.V-5 manual standby liquid control system initiation (4.5) 
P.5.V-6 system design to minimize condensation water hammer (4.2)

P.5.V-7 in-containment refueling water storage tank boiling suppression (5.3)

P.5.V-8 justification for use of remote manual valve for containment isolation (6.2)

P.5.V-9 evaluation of the ignition system for combustible gas control (6.6)

P.5.V-10 reliability of power supplies for severe-accident equipment (6.7)

P.5.V-11 detailed discussions regarding design-basis-accident events (9)

Chapter 6 - Building Design and Arrangement

P.6.V-1 method for inspecting structural degradation (2.1.1)

P.6.V-2 evaluation of the engineering backfill (2.1.1)

P.6.V-3 use of American National Standards Institute (ANSI) 10.4-1987 (2.1.1)

P.6.V-4 structural modules to be used in construction (2.2)

P.6.V-5 redundant non-safety-grade auxiliary systems within the plant protected area (2.3.3)

P.6.V-6 review of site-unique security and contingency plans (2.3.6)

P.6.V-7 programs for controlling and storing toxic materials (2.3.7)

P.6.V-8 shielding design requirements, shielding computer codes, and radioactive material sources (2.4)

P.6.V-9 use of ANSI/American Institute of Steel Construction N-690 (4.1.2 and 4.1 .3 )

P.6.V-10 evaluation of potential high-radiation areas (4.1.7)

P.6.V-11 design of the common basemat (4.1.9)

P.6.V-12 reinforced-bar design criteria for vinyl-coated rebars (4.1.9)

P.6.V-13 material control provisions inside the containment (4.2.2 and 4.2.3)

P.6.V-14 control of access to the reactor containment (4.2.2 and 4.2.3)

P.6.V-15 design features that preclude potentially lethal radiation levels (4.2.2)

P.6.V-16 containment design details for aerosol and radioactive gases $(4.2 .3)$ 
P.6.1'-17 use of ANSI/ASME NOG-1, 1983 (4.2.3)

P.6.1'-18 design of the control complex (4.5.4)

\section{Chapter 7 - Fueling and Refueling Systems}

P.7.1-1 design of the overhead bridge crane (2.3.2)

P.7.V-2 high-radiation areas (2.3.7)

P.7.V-3 reactor disassembly and servicing equipment for BWRs (3.1.2)

Chapter 8 - Plant Cooling Water Systems

P.8.V-1 design requirements for the chilled water system (8)

P.8.V-2 time-delay allowance for fuel pool cooling capability (9)

Chapter 9 - Site Support Systems

P.9.V-1 separation of redundant shutdown equipment in the containment $(3.3 .1)$

P.9.V-2 underfloor or ceiling control room cable fires (3.4)

P.9.V-3 security area devitalized during unit shutdown (5.1)

P.9.V-4 security for components that manipulate vital isolation valves $(5.2 .1)$

P.9.V-5 non-safety-related auxiliary systems within the protected area (5.2.1)

P.9.V-6 sabotage vulnerability analysis (5.2.2)

P.9.V-7 charcoal filters in air filtration systems $(8.2 .4,8.2 .5,8.3 .3$, 8.4 .1 , and 8.4.2)

P.9.V-8 safety classification of fuel facility ventilation supply subsystem $(8.2 .4)$

P.9.V-9 safety classification of PWR auxiliary building ventilation supply subsystem (8.4.2)

Chapter 10 - Man-Machine Interface Systems (M-MIS)

P.10. V-1 acceptable interpretations of requirements (1)

P.10.1-2 software protection (2.3)

P.10.1/-3 level of automation (2.3)

P.10.1-4 defense-in-depth and diversity analysis (2.3 and 4.5) 
P.10.V-5 review of equipment used for displays to the operator (2.3)

P.10.V-6 methods to ensure operator alertness (2.3)

P.10.V-7 additional criteria for developing technology (2.3)

P.10.V-8 independence of verification and validation review teams (3.1.2)

P.10.V-9 use of commercial-grade equipment (3.1.2)

P.10.V-10 complexity of M-MIS (3.1.3)

P.10.V-11 use of unproven technology (3.2.2)

P.10.V-12 quantitative reliability criteria (3.5)

P.10.V-13 selection of equipment failure modes (3.5.1 and 6.2.7)

P.10.V-14 maintenance frequency (3.5.2)

P.10.V-15 reliability analysis (3.5.4)

P.10.V-16 automatic reconfiguration after failure detection (3.6.4)

P.10.V-17 surveillance period of automatic testing features (3.6.8)

P.10.V-18 automatic bypass initiation (3.6.10, 3.6.13, and 3.6.14)

P.10.V-19 module software concerns $(3.7 .4)$

P.10.V-20 bypass and test lockouts during on-line repairs $(3.7 .6)$

P.10.V-21 main control room staffing (4.2)

P.10.V-22 alarm suppression techniques (4.3.3)

P.10.V-23 use of "dial-up" telephone-type portable radios for security purposes $(4.6 .3)$

P.10.V-24 unauthorized access to equipment in remote shutdown stations $(4.9 .1)$

P.10.V-25 computer room within the main control room security boundary (4.9.1)

P.10.V-26 design of emergency operations facility (4.9.4)

P.10.V-27 modification of security boundaries during an emergency (4.9.4)

P.10.V-28 data storage methods (4.9.4)

P.10.V-29 compliance of perimeter intrusion alarm system with 10 CFR $73.55(\mathrm{~h})$ (5.2.1 and 5.2.5) 
P.10.V-30 signal transport delay (5.2.5)

P.10.V-31 analog-to-digital and digital-to-analog converters (5.7)

P.10.V-32 software requirement specification (6.1.2 and 6.1.6)

P.10.V-33 verification of software (6.1.2)

P.10.V-34 documentation of testing and verification of commercially available software (6.1.2)

P.10.V-35 configuration control of software purchased through software clearinghouses (6.1.2)

P.10.V-36 specific methods used to meet the requirement for diversity (6.1.6)

P.10.V-37 elimination of electromagnetic interference (6.2.2)

P.10.V-38 signal validation methodology (6.2.2)

P.10.V-39 restoration state of control system components after loss of power (6.3.2)

P.10.V-40 setting resolution for control parameters (6.3.3)

P.10.V-41 neutron monitoring M-MIS (7.4)

P.10.V-42 selection of variables for automatic actuation (8.2.3)

P.10.V-43 radiation monitor placement, calibration frequency, and emergency power provisions (10.2.1)

P.10.V-44 compliance with Item II.F.1.3 of NUREG-0737 (10.2.1)

P.10.V-45 criteria for airborne reactivity monitors (10.2.1)

P.10.V-46 operating philosophy (2 of Appendix B)

P.10.V-47 use of mockups, prototypes, and simulators (2 of Appendix B)

Chapter 11 - Electric Power Systems

P.11.V-1 reliance on the non-safety electrical systems beyond 72-hour period (2.2.2)

P.11.V-2 reliance on the non-safety electrical systems to achieve cold shutdown (2.2.2)

P.11.V-3 applicable regulations and regulatory guidances that are not addressed in Chapter 11. (2.2.3)

P.11V-4 minimization of Class IE components (2.2.4) 
P.11.V-5 use of revisions of IEEE standards not endorsed by the staff (2.2.7)

P.11.V-6 operating conditions of all plant loads for all relevant grid conditions and the design of the bus voltage protection schemes (3.2.4)

P.11.V-7 design of the standby power source starting system (5.2.6)

P.11.V-8 design of the standby power source fuel oil storage and transfer system (5.2.6)

P.11.V-9 design of the electrical separation of dc and vital ac power supply systems (7.2.5)

P.11.V-10 integration of the exterior lighting system with the closed-circuit television system (8.2.4)

Chapter 12 - Radioactive Waste Processing Systems

P.12.V-1 requirements for radioactive waste processing systems and effluent paths (2.2.8)

P.12.V-2 gaseous radioactive waste processing system hydrogen control design (3.3.4)

P.12.V-3 design of dry waste shipping containers (5.5)

Chapter 13 - Main Turbine-Generator Systems

P.13.V-1 use of seismic experience data base and analysis for SSE loading conditions (3.1.1)

P.13.V-2 one piece rotor design part machining inspection requirements (3.1.5)

P.13.V-3 prototype testing of new or significantly changed turbine-generator designs (3.1.6 and 4.1.1) 


\section{CONCLUSION}

Requirements Document for Evolutionary Plant Designs

Subject to the resolution of the identified outstanding policy issues and vendor- and utility-specific items discussed in the SER (Volume 2 of this report), the staff concludes that the requirements established in the Requirements Document for evolutionary plant designs (Volume II) do not conflict with current regulatory guidelines and are acceptable. However, by themselves they do not provide sufficient information for the staff to determine if the plant design will be adequate. Therefore, applicants referencing the Requirements Document will be required to demonstrate compliance with the additional guidance provided in the Standard Review PIan (NUREG-0800), or provide justification for alternative means of implementing the associated regulatory requirements.

In the staff requirements memorandum (SRM) of August 24,1989 , the Commission instructed the staff to provide an analysis detailing where the staff proposes departure from current regulations or where the staff is substantially supplementing or revising interpretive guidance applied to currently licensed light water reactors (LWRs). The staff considers these to be policy issues. Appendix B to Chapter 1 of Volume 2 of this report gives the staff's regulatory analysis of those issues identified for these designs. These issues have been addressed in SECY-90-016 and SECY-91-078, and in draft Commission papers, "Issues Pertaining to Evolutionary and Passive Light Water Reactors and The ir Relationship to Current Regulatory Requirements, "and "Design Certification and Licensing Issues Pertaining to Passive and Evolutionary Advanced Light Water Reactor Designs, " that were issued on February 27 and July 6, 1992, respectively.

In its SRMs dated June 26, 1990, and April 15, 1991, the Commission provided its decisions on SECY-90-016 and SECY-91-078 as they apply to evolutionary designs.

The February 27 and July 6, 1992, draft Commission papers have been forwarded to the Advisory Committee on Reactor Safeguards. The staff will include its views in the final papers and document its final positions before seeking Cominission approval. When the staff finalizes these Commission papers, the Cominission will complete its review of the basis for the approach that the staff is proposing for those issues and, accordingly, may at some future point in the review determine that such issues involve policy questions that the Cominission may wish to consider. The approaches to resolving these issues havi not been reviewed by the Commission, and, therefore, do not represent age'cy positions.

The refore, the staff concludes that EPRI's ALWR Utility Requirements Document for evolutionary $\mathrm{plant}$ designs (Volume II) specifies requirements that, subject to the resolution of the identified outstanding policy issues and ventor- and utility-specific items, if properly translated into a design and constructed and operated in accordance with the NRC regulations in force at the time the design is submitted, should result in a nuclear power plant that 
will have all the attributes required to ensure that there is no undue risk to the health and safety of the public or to the environment. In addition to complying with existing regulations, such a facility would also be consistent with the Commission's policies on severe-accident protection.

Requirements Document for Passive Plant Designs

Subject to the resolution of the identified outstanding issues and vendor- and utility-specific items listed in Sections 1.4 and 1.5 of each DSER chapter or appendix issued on April 24, 1992, the staff concludes that the requirements established in the Requirements Document for passive plant designs (Volume III) do not conflict with current regulatory guidelines and are acceptable. However, by themselves they do not provide sufficient information for the staff to determine if the plant design will be adequate. Therefore, applicants referencing the Requirements Document will be required to demonstrate compliance with the additional guidance provided in the Standard Review Plan (NUREG-0800), or provide justification for alternative means of implementing the associated regulatory requirements.

In its August 24, 1989, SRM, the Commission instructed the staff to provide an analysis detailing where the staff proposes departure from current regulations or where the staff is substantially supplementing or revising interpretive guidance applied to currently licensed LWRs. The staff considers these to be policy issues. Appendix B to the DSER on Chapter 1 of the Requirements Document for passive plant designs gives that analysis. The staff forwarded these issues to the Commission in draft Commission papers dated February 27 and JuTy 6, 1992. When the staff finalizes these Commission papers, the Commission will complete its review of the basis for the approach that the staff is proposing for those issues and, accordingly, may at some future point in the review determine that such issues involve policy questions that the Commission may wish to consider. The approaches to resolving these issues have not been reviewed by the Commission, and, therefore, do not represent agency positions.

In addition, certain technical issues still have to be resolved before the staff can complete its review.

The following conclusions are based on the staff's review as documented in the April 1992 draft SER (Volume 3 of this report). The final SER, scheduled to be issued in September 1993, will give the final results of the staff's review of EPRI's ALWR Utility Requirements Document for passive ALWR designs.

Therefore, on the basis of its review to date, the staff concludes that EPRI's ALWR Utility Requirements Document for passive plant designs (Volume III) specifies requirements that, subject to the resolution of the identified outstanding issues and vendor-and utility-specific items, if properly translated into a design and constructed and operated in accordance with the NRC regulations in force at the time the design is submitted, should result in a nuclear power plant that will have all the attributes required to ensure that there is no undue risk to the health and safety of the public or to the environment. In addition to complying with existing regulations, such a facility would also be consistent with the Commission's policies on severeaccident protection. 


\section{APPENDIX A}

\section{CHRONOLOGY OF CORRESPONDENCE}

This appendix contains a chronological listing of routine licensing correspondence between the U.S. Nuclear Regulatory Commission (NRC) staff and the Electric Power Research Institute (EPRI) and other correspondence related to Project 669.

JuTy 14,1981

Letter from J. C. Mark, Advisory Committee on Reactor Safeguards (ACRS), to NRC submitting suggestions regarding potential safety improvements for incorporation into new designs for nuclear power plants. NRC should give appropriate priority and resources to developing safety requirements for future LWRs.

September 15, 1982 Letter from S. Burstein, EPRI, to NRC discussing proposed NRC involvement in steering committee program for developing standardized LWR design as discussed at July 20, 1982, meeting. Participation required in policy committee and program group.

October 20, 1982

Letter from $H . R$. Denton, NRC, to EPRI, responding to September 15, 1982, letter requesting NRC participation in EPRI's Standardized LWR Design Program. NRC involvement in program to prove beneficial to both NRC and EPRI. Meeting requested.

October 27, 1982 Letter from C. 0. Thomas, NRC, to EPRI, summarizing October 21 , 1982, meeting with EPRI regarding LWR standardization program. Development of LWR plant baseline designs and approach that could be used by vendors in obtaining certification of plant design emphasized in EPRI program.

December 20, 1982 Letter from S. Burstein, EPRI, to NRC, requesting that meeting between Utility Steering Committee for EPRI's Standardized LWR Design Program and NRC Policy Committee be held on February 9, 1983, in Bethesda, Maryland, to discuss plans for standardized design. Related information enclosed.

January 21, 1983 Letter from D. H. Moran, NRC, to EPRI, summarizing January 12, 1983, meeting with EPRI in Bethesda, Maryland, regarding review of licensing issues to be considered in LWR standardization program.

January 27, 1983 Letter from R. E. Nickell, EPRI, to NRC, confirming highpriority safety and licensing issues selected at meeting 
February 21, 1983

February 28, 1983

March 10, 1983

March 10, 1983

May 14,1983

May 25, 1983

June 23, 1983

September 16, 1983

November 4, 1983 on January 12, 1983, with emphasis on revision of Appendix $R$ to 10 CFR Part 50, decay heat removal (DHR), and high-strength bolting. Possible items for discussion at February 9, 1983, meeting suggested.

Letter from EPRI to NRC, requesting meeting between NRC Policy Committee and Utility Steering Committee for EPRI's Standardized LWR Design Program.

Letter from D. H. Moran, NRC, to EPRI, summarizing February 14, 1983, meeting with EPRI in Bethesda, Maryland, regarding current status and progress to date of LWR standardization program.

Letter from $H$. Denton, NRC, to EPRI, responding to February 21, 1983, request for meet ing between NRC Policy Committee and Utility Steering Committee for EPRI's Standardized LWR Design Program. Meeting to be held on April 6, 1983, in Bethesda, Maryland.

Letter from D. H. Moran, NRC, to EPRI, summarizing February 22, 1983, meeting with EPRI and Sol Levy Associates in Palo Alto, California, regarding final priority sequence and relegation of nonapplicable safety issues to inactive status and consolidation of information on resolution of unresolved issues.

Letter from S. Burstein, NRC, to EPRI, confirming action items resulting from meeting with Utility Steering Committee for EPRI Standardized LWR Plant Design Evaluation Program on April 6, 1983, meeting. Formal plan should be developed for cooperative efforts between NRC and EPRI. Related information enclosed.

Letter from D. H. Moran, NRC, to EPRI, forwarding (1) draft task action plan, Revision 2 for Task A-45 regarding shutdown DHR requirements and (2) a paper on same subject presented before Swiss Federal Institute for Reactor Research in late April 1983.

Letter from R. E. Nickell, EPRI, to NRC, acknowledging receipt of Revision 2 of draft task action plan for Task A-45 regarding shutdown DHR requirements and giving detailed program plan discussed at June 7-15, 1983, meetings. Related information enclosed.

Letter from D. H. Moran, NRC, to EPRI, summarizing August 11 , 1983, meeting with Utility Steering Committee for EPRI Standardized LWR Plant Design Evaluation Program in Bethesda, Maryland, regarding progress of standardized design program.

Letter from H. R. Denton, NRC, to EPRI, forwarding review of EPRI list of generic issues not applicable to 
Noveniber 29, 1983

Apri1 3, 1984

Apri1 20, 1984

June 12,1984

September 11, 1984

October 17, 1984

January 23, 1985

February 7, 1985

Apri1 4, 1985 certification of future LWR standardized plants, as committed to at August 11,1983 , meeting. Results to be discussed at November 7, 1983, meeting.

Letter from D. H. Moran, NRC, to EPRI, summarizing November 7, 1983, meeting with EPRI Utility Steering Committee for LWR Standardized Plant Design Evaluation Program regarding corroboration of issues not applicable to certification of future LWR plants. Agenda and viewgraphs enclosed.

Letter from D. H. Moran, NRC, to EPRI, summarizing February 16, 1984, meeting with EPRI in Bethesda, Maryland, regarding evaluation of LWR standardized plant design. List of attendees, agenda, and viewgraphs enclosed.

Letter from $H$. R. Denton, NRC, to ACRS, requesting that ACRS comment on correctness of categorization of generic safety and licensing issues, identifying which issues affect future LWR standardized plant designs.

Letter from D. H. Moran, NRC, to EPRI, summarizing NRC Policy Committee and EPRI Utility Steering Committee for LWR Standardization Plant Design Evaluation fifth quarterly meeting on May 23, 1984, in Bethesda, Maryland. List of attendees and viewgraphs enclosed.

Letter from J. C. Ebersole, ACRS, to NRC, discussing proposed categorization of generic safety and licensing issues, identifying which issues affect future LWR standardized plant designs. EPRI's plan for issue resolution would require considerable resource allocation.

Letter from H. R. Denton, NRC, to ACRS, responding to ACRS September 11, 1984, letter regarding EPRI categorization of generic safety and licensing issues. Resource plan being drafted to consider resources required for appropriate review.

Letter from D. H. Moran, NRC, to EPRI, summarizing December 5, 1984, meeting with EPRI Utility Steering Committee for LWR Standardized Plant Design Evaluation. Commission approval of resource expenditures contingent on EPRI presentation showing rapid progress.

Transcript of Commission February 7, 1985, meeting in Washington, DC, regarding NRC briefing on standard design process. Pp 1-66. Supporting documentation enclosed.

Letter from S. Burstein, EPRI, to NRC, forwarding expanded writeups for shutdown DHR, emergency core cooling system methodology, and high-strength bolting 
June 4,1985

October 15,1985

October 15, 1985

December 2, 1985

December 3, 1985

December 27, 1985

January 24, 1986

March 7, 1986

March 24, 1986 topics. Discussion of expanded format and agenda of April 11, 1985, NRC Policy Committee and EPRI Utility Steering Committee meeting requested.

Letter from D. H. Moran, NRC, to EPRI, summarizing Apri7 4, 1985, meeting with EPRI Utility Steering Committee for LWR Standard Plant Design Evaluation in Bethesda, Maryland, regarding status of EPRI/industry ALWR program and of safety and licensing issues.

Letter from D. H. Moran, NRC, to EPRI, summarizing August 27 and 28, 1985, working meetings in Bethesda, Maryland of EPRI and NRC project and task managers regarding listed generic safety issues affecting EPRI/industry ALWR Utility Requirements Document. Agenda and summary of remaining and forecast issues enclosed.

Letter from D. H. Moran, NRC, to EPRI, summarizing September 12, 1985, quarterly meeting with EPRI Utility Steering Committee for LWR Standardized Plant Design Evaluation regarding status of ALWR program. Agenda, viewgraphs, and list of attendees enclosed.

Letter from D. H. Moran, NRC, to EPRI, summarizing October 28-30, 1985, working meetings with EPRI and NRC project managers regarding resolution of generic safety and licensing issues. Agenda, list of attendees, and summary of remaining and new issues enclosed.

Letter from C. F. Sears, EPRI, to NRC, forwarding draft "NRC Issue and Document Review Process for EPRI/Industry Advanced LWR Program." Comments requested by January 15, 1986.

Letter from D. H. Moran, NRC, to EPRI, summarizing EPRI Utility Steering Committee for LWR Standardized Plant Design Evaluation and NRC Policy Committee meeting on December 3, 1985, in Bethesda, Maryland, regarding status of ALWR program. List of attendees, agenda, and handouts enclosed.

Letter from T. P. Speis, NRC, to EPRI, forwarding comments on topical report submitted on December 3, 1985, regarding ALWR Requirements Document, Chapter 1.

Letter from T. P. Speis, NRC, to EPRI, commenting on draft material regarding ALWR program and NRC review process. Draft submittal good description of program to date and good base to develop NUREG on ALWR program.

Letter from C. F. Sears, EPRI, to NRC, forwarding "Advanced LWR Plant Optimization Subjects for Chapter 1 of Requirements Document." Optimization subjects 
June 5,1986

June 6,1986

June 10,1986

June 30,1986

JuTy 8, 1986

July 8, 1986

September 9, 1986

Octotier 15, 1986

December 9, 1986 addressed current regulations that might be overly conservative. Response requested by April 30, 1986.

Letter from D. H. Moran, NRC, to EPRI, summarizing March 12, 1986, meeting with ALWR Utility Steering Committee regarding current status of ALWR program. List of attendees, agenda, and related information enclosed.

Letter from T.P. Speis, NRC, to EPRI, responding to request for review and opinion of "Advanced LWR Plant Optimization Subjects for Chapter 1 of Requirements Document." Optimization subjects in conformance with August 8, 1985 severe-accident policy.

Letter from D. H. Moran, NRC, to EPRI, forwarding trip report of attendance at May 5-7, 1986, working meetings with EPRI regarding draft Chapter 2 of Utility Requirements Document and NUREG-1197, "Advance Light Water Reactor Program - Program Management and Staff Review Methodology." Viewgraphs, agenda, and related information enclosed.

Letter from EPRI to NRC; forwarding executive summary of ALWR Utility Requirements Document.

Letter from C. F. Sears, EPRI, to NRC, discussing program to develop requirements for ALWRs to resolve generic safety and licensing issues applicable to future LWRs, through NRC, EPRI, and ALWR Utility Steering Committee efforts.

Letter from C. F. Sears, EPRI, to NRC, forwarding information on four safety and licensing issues from generic list of issues being evaluated for resolution via EPRI ALWR program, for comment.

Letter from D. H. Moran, NRC, to EPRI, summarizing ALWR Utility Steering Committee and NRC Policy Committee July 8, 1986, meeting in Bethesda, Maryland, regarding enclosed 1 ist of agenda items, including ALWR program support. Supporting documentation enclosed.

Letter from C. F. Sears, EPRI, to NRC, forwarding Chapter 2 of ALWR Utility Requirements Document." Chapter contained utility requirements for main and extraction steam, feedwater and condensate, chemical addition, condensate makeup purification, and auxiliary steam.

Letter from T. P. Speis, NRC, to EPRI, responding to July 8,1986 , request for comments on topic papers regarding Chapter 3 of ALWR Utility Requirements Document. Recommended that pump seal issue be resolved. 
January 5, 1987

January 15, 1987

February 2, 1987

February 9, 1987

February 26, 1987

March 2, 1987

March 5, 1987

March 11, 1987

March 18, 1987

March 27, 1987
Letter from T. P. Speis, NRC, to EPRI, forwarding questions and comments resulting from review of EPRI ALWR Utility Requirements Document, Chapter 1. Response requested by February 28, 1987, to support NRC completion of draft safety evaluation report (DSER) on Chapter 1.

Letter from $W$. Kerr, ACRS, to NRC, summarizing ACRS 321 st meeting on January 8-10, 1987, regarding improved safety requirements and objectives for future LWRs.

Letter from T. P. Speis, NRC, to EPRI requesting that EPRI submit comments via ALWR Utility Steering Committee regarding ACRS recommendations on improved safety requirements and objectives for future LWR plants. Comments requested by February 27, 1987.

Letter from R. M. Bernero, NRC, to EPRI, forwarding ACRS January 15, 1987, letter presenting recommendations on improved safety design features for future LWRs. Comments in support of NRC and ACRS review of General Electric's Advanced Boiling Water Reactor (ABWR) requested by February 27, 1987.

Letter from H. R. Denton, NRC, to multiple recipients, forwarding executive summary of ALWR Utility Requirements Document. Document to provide specific attributes desired for plants of 1990 s and beyond.

Letter from L. J. Ybarrondo, NRC contractor, to NRC, forwarding "Independent Assessment of 'Advanced LWR Utility Requirements Document Chapter 1: Overal1 Requirements'.

Letter from D. H. Moran, NRC, to EPRI, summarizing October 15, 1986, quarterly meeting with ALWR Utility Steering Committee and NRC Policy Committee. List of attendees, agenda, and viewgraphs enclosed.

Letter from T. P. Speis, NRC, to EPRI, forwarding questions and comments from Sections 2 and 3 of Scientech Report SCIE-022-87 for January 1987. EPRI response to questions and comments requested by March 31, 1987. Report not enclosed.

Letter from T.P. Speis, NRC, to EPRI, requesting additional information regarding review of ALWR Utility Requirements Document, Chapter 1 . Response requested by April 15, 1987.

Letter from E. E. Kintner, EPRI, to NRC, forwarding responses to independent review comments on ALWR Utility Requirements Document, Chapter 1 , in response to January 5, 1987, letter. Chapters 3 and 4 to be submitted in June 1987. 
March 27, 1987

Apri1 10, 1987

April 15, 1987

Apri1 22, 1987

April 23, 1987

April 29, 1987

May j, 1987

May 15,1987

May 18,1987

May :?1, 1987
Letter from E. E. Kintner, EPRI, to NRC, forwarding comments on ACRS recommendations. Opportunity welcomed for early dialogue with NRC and ACRS on important safety issues in ALWR program.

Letter from H. D. Curet, EPRI, to NRC, "Preliminary Comments on ALWR Utility Requirements Document, Chapter 2: Power Generation System."

Letter from D. A. Meneley, University of Fredericton, New Brunswick, to NRC, responding to $H$. Denton request for comments dated February 26, 1987, regarding executive summary of ALWR Utility Requirements Document. Program of regular measurement and reporting of reliability data for key safety systems at each plant recommended.

Letter from H. D. Curet, EPRI, to NRC, forwarding suggested modifications of Page 3 of Modification 2 to Contract NRC-03-86-057, "Independent Assessment of Advanced LWR Utility Requirements Documentation," and revised comments on Chapter 2 of ALWR Utility Requirements Document.

Letter from H. D. Curet, EPRI, to NRC, forwarding replacement pages 1-3 of "Preliminary Comments on Advanced LWR Utility Requirements Document, Chapter 2: Power Generation System."

Letter from M. M. Yedidia, EPRI, to NRC, forwarding abstracts for Chapters 2-13 of ALWR Utility Requirements Document .

Letter from R. T. Dewling, NRC contractor, to NRC, responding to $H$. $R$. Denton request for views on $A L W R$ Utility Requirements Document. Convincing evidence needed that ALWRs major step forward in improving plant safety.

Letter from L. J. Ybarrondo, NRC contractor, to NRC, forwarding "Technical Evaluation of Chapter 2: Power Generation System of Advanced LWR Utility Requirements Document."

Letter from H. D. Curet, EPRI, to NRC, forwarding "Technical Evaluation of Chapter 2: Power Generation System of Advanced LWR Utility Requirements Document."

Letter from D. Crutchfield, NRC, to EPRI, requesting description of quality assurance (QA) program applied during preparation of ALWR Utility Requirements Document and $Q A$ program to be applied to ensure that future changes would be made in controlled fashion. NUREG-0800 and Regulatory Guide 1.28 enclosed. 
May 27, 1987

May 31, 1987

June 1,1987

June 5,1987

June 5,1987

June 9,1987

June 12,1987

June 15,1987

June 18,1987

June 22, 1987

June 30,1987
Letter from $P$. H. Leech, NRC, to EPRI, requesting additional information on Chapter 2 of ALWR Utility Requirement Document. Comments and questions by NRC and Scientech, Inc., provided in Enclosures 1 and 2 respectively. Response expected by September 1, 1987.

Letter from Duke Power Company, Westinghouse Electric Corporation, and CYGNA Energy Services, to NRC, forwarding EPRI NP-5159 "Guidel ines for Specifying Integrated Computer-Aided Engineering Applications for Electric Power Plants," .

Letter to NRC forwarding comments on the executive summary for EPRI's ALWR Utility Requirements Document.

Letter from H. N. Berkow, NRC, to R.T. Dewling, acknowledging receipt of May 6, 1987, letter commenting on ALWR Utility Requirements Document executive summary. Comments forwarded to EPRI for consideration in preparing rest of Requirements Document.

Letter from H. N. Berkow, NRC, expressing appreciation for June 1, 1987, comments on ALWR Utility Requirements Document executive summary. Letter forwarded to EPRI for information.

Letter from H. D. Curet, EPRI, to NRC, forwarding revised page 4 of "Technical Evaluation of Chapter 2: Power Generation System of Advanced LWR Utility Requirements Document."

Letter from P. H. Leech, NRC, to EPRI, requesting additional information on Chapter 2 of ALWR Utility Requirements Document, including description of live loading for valve packing developed by Atomic Energy of Canada, Limited (AECL) for CANDU plants, in accordance with May 27, 1987, request.

Letter from L. J. Ybarrondo, NRC contractor, to NRC, forwarding "Independent Assessment of Advanced LWR Utility Requirements Document," final monthly progress report for May 1987.

Letter from E. E. Kintner, EPRI, to NRC, forwarding Revisions 0 of Chapters 3 and 4, of ALWR Utility Requirements Document for review.

Letter from P. Leech, NRC, to EPRI, summarizing June 17 , 1987, meeting with EPRI representatives in Bethesda, Maryland, regarding briefing of new NRC reviewers of ALWR Utility Requirements Document. List of attendees and viewgraphs enclosed.

"Standard Plant Reviews Program Plan" 
June 30,1987

June 30,1987

July 9, 1987

July 20, 1987

Ju1y 22, 1987

Septenber 17,1987

Septenber 24, 1987

Septenber 24, 1987

Octobır 6, 1987

Octobier 12, 1987

Novemlser 13, 1987
Letter from EPRI, to NRC, forwarding Revision 0 of Chapter 4 of ALWR Utility Requirements Document.

Letter from EPRI, to NRC, forwarding Revision 0 of Chapter 3 of ALWR Utility Requirements Document.

Letter from E. E. Kintner, EPRI, to NRC, forwarding six topic papers on generic issues pertaining to Chapters 1 , 3 , and 4 , and optimization subject paper regarding Chapter 3 of ALWR requirements document.

Letter from P. H. Leech, NRC, to EPRI summarizing July 1 , 1987, meeting with EPRI and Chairman of ALWR Utility Steering Committee regarding ALWR program. List of attendees and viewgraphs enclosed.

Letter from E. E. Kintner, EPRI, to NRC, responding to May 21, 1987, request to provide description of QA program applied during preparation of ALWR Utility Requirements Document. QA program not called for according to SRP Section 17.1 and Regulatory Guide 1.28.

Letter from E. E. Kintner, EPRI, to NRC, forwarding response to May 27 and June 12, 1987, questions and comments on Chapter 2 of ALWR Utility Requirements Document. Chapters 3 and 4 under NRC review. Chapter 5 should be available for review by end of November.

Letter from R. W. Hernan, NRC, to ACRS, forwarding September 24, 1987, DSER on Chapter 1 of ALWR Utility Requirements Document. Additional DSERs on subsequent chapters to be provided when complete. Information would support ACRS 0ctober 6, 1987, meeting.

Letter from L. S. Rubenstein, NRC, to EPRI, forwarding DSER on Chapter 1 of ALWR Utility Requirements Document. Findings generally favorable to ALWR program.

Transcript of ACRS Standardization of Nuclear Facilities Subcommittee meeting on 0ctober 6, 1987, in Washington, D.C. Pp 1-205. Supporting documentation enclosed.

Letter from J. C. Devine, EPRI, to NRC, commenting on proposed new SRP Section 3.6.3 regarding leak-before-break evaluation procedures. Proposed approach would severely limit application of leak-before-break technology for future plants and not achieve intent of General Design Criterion 4 of Appendix $A$ to 10 CFR Part 50.

Letter from $P$. H. Leech, NRC, to EPRI, requesting additional information on ALWR Utility Requirements 
November 24, 1987

December 1,1987

December 8, 1987

December 11, 1987

January 19, 1988

January 25, 1988

January 25, 1988

January 27,1988

February 5, 1988

February 18, 1988
Document, Chapters 3 and 4 . Schedule for review of Chapters 3 and 4 based on receipt of response by December 31, 1987.

Letter from A. E. Scherer, Combustion Engineering, Inc., to NRC, forwarding proposed Advanced Reactor Severe Accident Program resolutions for four remaining NRC/Industry Degraded Core Rulemaking (IDCOR) severeaccident issues. Six valid DOE/IDCOR resolutions to be adopted in developing System $80+$ design. Concurrence requested.

Letter from L. S. Rubenstein, NRC, to EPRI, forwarding list of significant technical issues that might arise during review of evolutionary standard ALWR plants. Comments requested.

Letter from E. E. Kintner, EPRI, to NRC, forwarding Revision 0 of ALWR Utility Requirements Document, Chapter 5 , for review.

Letter from P. H. Leech, NRC, to EPRI, requesting additional information on Chapters 3 and 4 of ALWR Utility Requirements Document. Notification requested in case response delayed more than 2 to 3 weeks beyond December $31,1987$.

Letter from L. S. Rubenstein, NRC, to EPRI, forwarding status report on technical reviews of standardized plant designs for January 1988. Problem meeting 1 isted input dates requested within 1 week of receipt of letter.

Letter from D. Crutchfield, NRC, to EPRI, forwarding information on ALWR performance goals. Information assembled after discussion with knowledgeable NRC staff members and during January 19, 1988, meeting with EPRI representatives.

Letter from E. E. Kintner, EPRI, to NRC, forwarding additional information on Chapters 3 and 4 of ALWR Utility Requirements Document in response to a11 but two questions in November 13 and December 11, 1987 letters.

Letter from L. S. Rubenstein, NRC, to EPRI, requesting additional information regarding design goals addressing severe-accident releases. Response requested within 30 days of letter date.

Letter from Director, Office of Nuclear Reactor Regulation, to EPRI forwarding revised DSER on Chapter 1 of ALWR Utility Requirements Document.

Letter from L. S. Rubenstein, NRC, to EPRI, forwarding DSER on Chapter 2 ALWR Utility Requirements Document. 
February 18, 1988

Utility requirements in Chapter 2 are in general agreement with NRC guidelines and regulatory requirements for power generation system involved.

March 18, 1988

March 25, 1988

March 28, 1988

April 4, 1988

Apri1 6, 1988

May 13, 1988

May 31,1988

June 3,1988

Letter from L. S. Rubenstein, NRC, to Committee to Review Generic Requirements (CRGR), forwarding DSER on Chapter 2 of ALWR Utility Requirements Document and informing CRGR members and staff of progress in reviewing Requirements Document.

Letter from P. H. Leech, NRC, to EPRI, requesting additional information on Chapter 5 of ALWR Utility Requirements Document. Current schedule of review based on receipt of response by April 29, 1988. Notification expected if delay anticipated.

Letter from L. S. Rubenstein, NRC, to EPRI, forwarding safety evaluation of recommended modifications of Regulatory Guide 1.76, "Design Basis Tornado for Nuclear Power Plants." NRC interim position constitutes conservative reduction of design-basis winds for use by EPRI until revision available.

Letter from E. E. Kintner, EPRI, to NRC, forwarding responses to Questions 36 and 40 to resolve NRC comments regarding ALWR low temperature overpressure protection requirements.

Letter from P. H. Leech, NRC, to EPRI, requesting additional information on Chapter 5 of ALWR Utility Requirements Document. Response to questions requested by April 29, 1988.

Letter from E. E. Kintner, EPRI, to NRC, providing initial response to January 27,1988 , questions on ALWR Utility Requirements Document regarding implementation of public safety criteria. Probabilistic risk assessment (PRA) key assumptions and groundrules to be submitted in September 1988 to provide more detail.

Letter from L. S. Rubenstein, NRC, to EPRI, forwarding DSER on Chapter 3 of ALWR Utility Requirements Document. Document in general agreement with NRC guidelines based on January 25 and March 25, 1988, letters regarding reactor coolant system and nonsafety auxiliary systems.

Letter from Director, Office of Nuclear Reactor Regulation, forwarding DSER on Chapter 3 of ALWR Utility Requirements Document.

Letter from Director, Office of Nuclear Reactor Regulation, Director, forwarding DSER on Chapter 4 of ALWR Utility Requirements Document. 
June 10,1988

June 20,1988

June 30,1988

July 31,1988

August 16,1988

September 15, 1988

September 23, 1988

September 23, 1988

October 26, 1988

November 1, 1988

November 17,1988
Letter from L. S. Rubenstein, NRC, to EPRI, forwarding DSER of Chapter 4 of ALWR Utility Requirements Document on the basis of commitments in January 25 and March 25, 1988 , letters.

Letter from L. S. Rubenstein, NRC, to ACRS, forwarding DSERs on Chapters 3 and 4 of ALWR Utility Requirements Document. Effort to continue until final SER issued in 1991 .

Report by Fauske and Associates, Inc., "Technical Support for Hydrogen Control Requirement for EPRI Advanced LWR Requirements Document Task 8.3.5.4," Advanced Reactor Severe Accident Program.

Letter from R. Stiger, International Technology Corp., to NRC, "Technical Basis for EPRI Advanced LWR Requirements Document Assumption on Delayed Fission Product Release (Task 8.3.5.2)," Advanced Reactor Severe Accident Program.

Letter from E. E. Kintner, EPRI, to NRC, forwarding responses to March 18 and Apri1 4, 1988, requests for additional information on Chapter 5 of ALWR Utility Requirements Document on station blackout.

Letter from E. E. Kintner, EPRI, to NRC, forwarding response to NRC Comments 430.1, 430.2, 430.3, and 430.4, regarding ALWR Utility Requirements Document and two reports referenced in responses to NRC Comments 480.5 and 450.1 .

Letter from W. 0. Long, NRC, to EPRI, regarding lowtemperature overpressure protection for ALWRs.

Letter from C. Y. Cheng, NRC, to EPRI, clarifying position on reactor vessel surveillance program and low temperature overpressure protection in Chapters 3 and 4 of ALWR Utility Requirements Document.

Letter from W. 0. Long, NRC, to EPRI, clarifying two statements in May 13,1988, DSER on Chapter 3 of ALWR Utility Requirements Document concerning chemical and volume control system.

Letter from W. 0. Long, NRC, to EPRI, summarizing October 26, 1988, meeting with EPRI in Rockville, Maryland, regarding NRC recommendations for design of ALWR electrical system. Meeting handout enclosed.

Letter from W. 0. Long, NRC, to EPRI, advising that open issue regarding suppression pool loads in Section 3.0.D.2 of Chapter 1 of ALWR Requirements Document needed further 
November 18,1988

November 22, 1988

December 23, 1988

December 30,1988

January 9, 1989

January 11, 1989

January 31,1989

February 2, 1989

February 6, 1989

February 23, 1989 clarification. Section not clear on whether proposed leak-before-break proposal consistent with General Design Criterion 4 of Appendix A to 10 CFR Part 50.

Letter from E. E. Kintner, EPRI, to NRC, forwarding Revision 0 of ALWR Utility Requirements Document Chapter 6, for review.

Letter from D. Crutchfield, NRC, to EPRI, forwarding information regarding scope of safety analys is report for future standardized design applications and NRC review of applications.

Letter from E. E. Kintner, EPRI, to NRC, forwarding ALWR Utility Requirements Document, Chapter 12.

Letter from E.E. Kintner, EPRI, to NRC, forwarding Revision 0 of ALWR Utility Requirement Document, Chapter 8.

Letter from B. Lee, Nuclear Management and Resources Council (NUMARC), to NRC, clarifying NUMARC position on need for NRC rulemaking on severe reactor accidents for ALWRs. Rulemaking not necessary and may be counterproductive.

Letter from E. E. Kintner, EPRI, to NRC, forwarding ALWR Requirements Document, Chapter 9, for use in chapter review.

Letter from D. G. Harrison, Idaho National Engineering Laboratory, to NRC, forwarding "Interim External Events Integration for EPRI Advanced LWR Requirements Document WBS 4.3.3."

Letter from W. 0. Long, NRC, to EPRI, discussing proposed resolutions of Generic Safety Issues I.F.1, "Expand QA List," and II.F.5 "Classification of Instrumentation and Electrical Equipment," and suggesting that EPRI reaffirm commitment in its December 3,1985, letter in order to resolve issues.

Letter from E. E. Kintner, EPRI, to NRC, forwarding ALWR Utility Requirements Document Chapter 13. Chapter incorporated lessons learned from evaluation of LWR technology as applied to generation of electricity.

Letter from $W$. 0 . Long, NRC, to EPRI, requesting additional information on ALWR Utility Requirements Document, Chapter 6. Information should be provided on level of detail consistent with Regulatory Guide 1.70 for safety analysis report. 
February 28, 1989

March 21, 1989

March 22, 1989

March 22, 1989

March 30, 1989

March 30, 1989

March 30, 1989

Apri1 3, 1989

April 5, 1989

April 10, 1989

Apri1 11, 1989
Letter from E. E. Kintner, EPRI, to NRC, forwarding ALWR Utility Requirements Document, Chapter 7.

Letter from $W .0$. Long, NRC, to EPRI, summarizing meeting on March 15, 1989, with EPRI and contractors in Palo Alto, California, regarding ALWR issues. List of attendees and handouts enclosed.

Letter from $W$. 0 . Long, NRC, to EPRI, requesting additional information on ALWR Utility Requirements Document, Chapters 8, 9, 12, and 13. Response requested within 60 days.

Letter from W. 0 . Long, NRC, to EPRI, requesting review of Chapter 7 of ALWR Utility Requirements Document. Schedule for review given.

Letter from E. E. Kintner, EPRI, to NRC, responding to open issue in DSER on Chapter 4 of ALWR Utility Requirements Document regarding capability of reactor pressure vessel to withstand multiple natural circulation cooldowns and to similar comment by ACRS on August 9, 1988.

Letter from E. E. Kintner, EPRI, to NRC, submitting additional information sufficient to resolve Generic Safety Issue (GSI) II.E.6.1, "In Situ Testing of Valves," ALWR Utility Requirements Document addressed subissues of GSI II.E.6.1. Concurrence on resolution of issue requested.

Letter from E. E. Kintner, EPRI, to NRC, responding to March 25, 1988, letter regarding optimization issue on tornado design in Chapter 1 of ALWR Utility Requirements Document. Agreed to use tornado design criteria in Table 2 and Figure 2 of safety evaluation for ALWR.

Letter from E. E. Kintner, EPRI, to NRC, forwarding additional information on outstanding issues in DSERs on Chapters 2, 3, and 4 of ALWR Utility Requirements Document.

Letter from E. E. Kintner, EPRI, to NRC, regarding GSIs I.F. 1 and II.F.5.

Letter from E. E. Kintner, EPRI, to NRC, forwarding ALWR Requirements Document, Chapter 11. EPRI believed major objectives had been achieved and concerns about station blackout would be virtually eliminated.

Letter from EPRI, to NRC, forwarding Revision 0 of ALWR Utility Requirements Document, Chapter 11. 
April 28, 1989

May 16,1989

May 17,1989

May :24, 1989

June 8,1989

June 16,1989

Ju7y 3, 1989

JuTy 3, 1989

July 14,1989

July 19,1989

August 18,1989
Letter from W. 0. Long, NRC, to EPRI, requesting additional information on ALWR Utility Requirements Document, Chapters 6, 7, 8, and 9 in accordance with March 22, 1988, request for additional information.

Letter from W. 0. Long, NRC, to EPRI, discussing ALWR Utility Requirements Document regarding tornado design. Position on tornado missile barriers given in SRP Sections 3.5.1.4, 3.5.2, and 3.5.3 and in Regulatory Guides 1.76 and 1.117 .

Letter from $W$. 0 . Long, NRC, to EPRI, giving notice of June 22, 1989, meeting with ALWR Utility Steering Committee in Rockville, Maryland, to discuss ALWR issues including program overview, hydrogen generation and ignition, and design-basis-accident source term assumptions.

Letter from $W$. Long to EPRI requesting additional information on Chapter $7,8,11$, and 12 of the ALWR Requirements Document.

Letter from $W$. 0. Long, NRC, to EPRI, requesting additional information on GLS-81-12 and 86-10.

Letter from W. 0. Long, NRC, to EPRI, regarding GSIs II.G.1 and II.G.23 pertaining to pressurizer equipment electric power and threat of reactor coolant pump seal loss of-coolant-accident.

Letter from E. E. Kintner, EPRI, to NRC, forwarding Revision 0 of ALWR Utility Requirements Document, Appendix $A$ to Chapter 1 . Appendix to provide guidance to be used in performing PRA.

Letter from E. E. Kintner, EPRI, to NRC, forwarding Chapter 6 of ALWR Utility Requirements Document.

Letter from J. L. Blaha, NRC, to EPRI, forwarding DSER on Chapter 1 of ALWR Utility Requirements Document and actual and estimated review schedule for ALWR project. Estimated dates preliminary and subject to revision after EPRI and NRC discussions.

Letter from T. Kenyon, NRC, to EPRI, summarizing June 22, 1989, meeting with EPRI representatives of nuclear power industry and source term and related issues for ALWR program. List of attendees and handouts enclosed.

Letter from E. E. Kintner, EPRI, to NRC, forwarding response to March 22 and April 28, 1989, letters regarding Chapters $6,7,8,9,12$; and 13 of ALWR Utility Requirements Document. 
September 15, 1989 Letter from E. E. Kintner, EPRI, to NRC, forwarding response to May 24,1989 , request for additional information on Chapters $7,8,11$, and 12 of ALWR Utility Requirements Document. Power supplies of emergency response facility system to be designed in accordance with NUREG-0696.

October 19, 1989 Letter from E. E. Kintner, EPRI, to NRC, forwarding additional information on Chapters 6,9 , and 11 of ALWR Utility Requirements Document in response to June 8 , 1989, request. ALWR to be in compliance with NUREG-0800 regarding enhanced fire protection.

October 26, 1989 Letter from E. E. Kintner, EPRI, to NRC, forwarding ALWR Utility Requirements Document, Chapter 10, and Topic Paper, "Reactor Pressure Vessel Level Instrumentation for PWRs."

November 6, 1989 Letter from J. L. Blaha, NRC, to SECY, forwarding correspondence between EPRI and NRC on Chapter 5 of ALWR Utility Requirements Document.

November 28, 1989 Letter from T. J. Kenyon, NRC, to EPRI, requesting information on reactor safeguards within 60 days of date of letter.

December 22, 1989 Letter from E. E. Kintner, EPRI, to NRC, forwarding responses to requests for additional information on Chapters $1,6,7,8,9,11$, and 13 of ALWR.

December 26, 1989 Letter from E. E. Kinter, EPRI, to NRC, regarding review priorities and process.

January 18, 1990 Letter from E. E. Kintner, EPRI, to NRC, forwarding responses to requests for additional information on Chapters $6,7,8,9,12$, and 13 of ALWR Utility Requirements Document regarding physical security, insider and outsider sabotage threats, and controlled access to the containment.

January 31, 1990. Report by Fauske and Associates, Inc., "Technical Support for Hydrogen. Control Requirement for EPRI Advanced LWR Requirements Document."

February 5, 1990 Letter from E. E. Kintner, EPRI, to NRC, forwarding "Technical Support for Hydrogen Control Requirement for EPRI Advanced LWR Requirements Document."

February 22, 1990 . Letter from E. E. Kintner, EPRI, to NRC, forwarding updated Revision 0 of ALWR Utility Requirements Document, Appendix $A$ to Chapter 1 . Document reissued to submit Section 3.2.2, "Earthquake," for NRC review. 
February 27, 1990

Febriary 28, 1990

March 16, 1990

March 29, 1990

March 31, 1990

Apri1 10, 1990

June 20, 1990

June 30,1990

Ju7y 3, 1990

July $3,199 \mathrm{C}$

July 13,1990
Letter from K. M. Carr, NRC, to EPRI, responding to December 26, 1989, letter expressing concerns regarding progress of NRC review of ALWR Utility Requirements Document.

Letter from C. L. Miller, NRC, to EPRI, forwarding DSER Chapter 5 on ALWR Utility Requirements Document, including severe-accident prevention and mitigation, hydrogen generation, control source term issues, and station blackout.

Letter from E. E. Kintner, EPRI, to NRC, forwarding response to request for additional information on Chapters 8 and 13 of ALWR Utility Requirements Document regarding remote positive indication of correct alignment of manual isolation valve and cast pressure-retaining parts of stop valves, respectively.

Letter from E. E. Kintner, EPRI, to NRC, regarding treatment of generic safety issues for ALWR requirements.

Letter from EPRI to NRC, forwarding Volume I, "ALWR Policy and Summary of Top-Tier Requirements," of ALWR Utility Requirements Document.

Letter from $T$. J. Kenyon, NRC, to EPRI, requesting additional information on Volume II of ALWR Utility Requirements Document on the basis of staff's review of Appendix A to Chapters 10 and 11 . Response requested within 60 days of letter date.

Letter from T. J. Kenyon, NRC, to EPRI, summarizing December 6, 1989, meeting with EPRI regarding Chapter 10 of Volume II of ALWR Utility Requirements Document. List of attendees and viewgraphs enclosed.

Report by Fauske and Associates, Inc., "Technical Support for Debris Coolability Requirements for Advanced LWRs in Utility-EPRI LWR Requirements Document."

Letter from S. H. Smith, Nuclear Power Oversight Committee, to NRC, advising NRC that U.S. utility industry vitally interested in timely certification of both evolutionary and passive ALWR designs currently under review by NRC. Maintaining current certification review schedules important.

Letter from E. E. Kintner, EPRI, to NRC, forwarding "Technical Support for Debris Coolability Requirements for Advanced LWRs in Utility-EPRI LWR Requirements Document."

Letter from T. J. Kenyon, NRC, to EPRI, requesting information needed to complete review of design criteria. 
July 23,1990

July 23,1990

August 2, 1990

August 2, 1990

August 8, 1990

August 13,1990

August 15,1990

August 22, 1990

August 23, 1990

August 27,1990
Letter from E. E. Kintner, EPRI, to NRC, forwarding response to April 10, 1990, request for additional information on Chapters 1, 10, and 11 of ALWR Utility Requirements Document.

Letter from EPRI, to NRC, forwarding "Prevention of Early Containment Failure Due to High Pressure Melt Ejection and Direct Containment Heating for Advanced LWRs."

Letter from T. J. Kenyon, NRC, to EPRI, requesting additional information on Chapter 10 of Volume II of ALWR Utility Requirements Document regarding electrical system.

Letter from T. J. Kenyon, NRC, to EPRI, summarizing May 31, 1990, meeting with EPRI, NUMARC and standardized plant vendors regarding Volume II of ALWR Utility Requirements Document. List of attendees enclosed.

Letter from T. J. Kenyon, NRC, to EPRI, summarizing May 31,1990 , meeting with EPRI regarding source term to be used for future LWR. List of attendees and viewgraphs enclosed.

Letter from J. M. Taylor, NRC, to S. H. Smith, Nuclear Power Oversight Committee, responding to July 3, 1990, letter to Chairman K. Carr regarding timely certification of two evolutionary passive designs. Sufficient time needed by NRC staff to identify and evaluate issues to ensure that proposed ALWR designs provide adequate protection.

Letter from T. J. Kenyon, NRC, to EPRI, forwarding comments regarding unresolved and generic safety issues addressed in Appendix B to Chapter 10 of Volume II of ALWR Utility Requirements Document.

Letter from T. J. Kenyon, NRC, to EPRI, requesting additional information on Volume II of ALWR Utility Requirements Document regarding design criteria. Response requested within 60 days of letter.

Letter from T. J. Kenyon, NRC, to EPRI, forwarding summary of Ju1y 16, 1990, meeting with EPRI regarding hydrogen generation and containment performance. List of attendees, NRC slides, and EPRI presentation enclosed.

Letter from T. J. Kenyon, NRC, to EPRI, forwarding revised request for additional information on Chapter 1 of Volume II of ALWR Utility Requirements Document. 
August 30,1990

August 31,1990

September 7, 1990

September 30,1990

October 12,1990

October 18, 1990

October 29,1990

November 7, 1990

Novemjer 29, 1990

Decemjer 6, 1990

December 21, 1990
Letter from T. J. Kenyon, NRC, to EPRI, requesting additional information on ALWR Utility Requirements Document, Volume I, and Chapters 1, 6, and 10 of Volume II to complete review of design criteria.

Letter from EPRI, to NRC, submitting annotated Revision 1 of Volume II to ALWR Utility Requirements Document.

Letter from E. E. Kintner, EPRI, to NRC, forwarding proprietary Revision 1 of Volume II (ALWR evolutionary plant) and Revision 0 of Volume III (ALWR passive plant) of ALWR Utility Requirements Document for safety evaluation review. Documents no longer withheld per March 29, 1991, letter from EPRI.

Report by D. E. Leaver and L. P. Tenera, "Licensing Design Basis Source Term Update for Evolutionary Advanced LWR."

Letter from E. E. Kintner, EPRI, to NRC, forwarding response to July 13 and August 2, 1990, requests for additional information on Chapters 7,10 , and 13 of ALWR Utility Requirements Document.

Letter from E. E. Kintner, EPRI, to NRC, forwarding "Licensing Design Basis Source Term Update for Evolutionary Advanced LWR."

Letter from W. R. Sugnet, EPRI, to NRC, forwarding tables listing NRC rules and regulatory guidance not in Appendix $B$ to Chapter I of Volumes II and III of Advanced LWR Utility Requirements Document.

Letter from E. E. Kintner, EPRI, to NRC, forwarding additional information on Appendix $A$ to Chapter 1 and Chapter 12 of ALWR Utility Requirement Document.

Transcript of closed-session meeting with ALWR Utility Steering Committee on November 29, 1990, with NRC. Pp 64-223. Supporting information enclosed. Transcript no longer proprietary per March 29, 1991 letter from EPRI.

Letter from E. E. Kintner, EPRI, to NRC, forwarding proprietary response to August 30,1990 , request for additional information on human factors considerations. Response addressed questions on ALWR Utility Requirements Document, Volume I, and Chapters 1, 6, and 10 of Volume II. Enclosure no longer withheld per March 29, 1991, letter from EPRI.

Letter from E. E. Kintner, EPRI, to NRC, forwarding response to request for additional information on unresolved and generic safety issues and addressing 
December 21, 1990

January 9, 1991

January 15, 1991

January 25, 1991

January 25, 1991

January 28, 1991

January 30, 1991

January 31,1991

February 1, 1991

February 4, 1991 questions on Volume II of ALWR Utility Requirements Document. Response no longer withheld per March 29, 1991 , letter form EPRI.

Letter from T. H. Boyce, NRC, to EPRI, forwarding notification of January 14, 1991, meeting with EPRI in Rockville, Maryland, to discuss seismic issues for ALWR Utility Requirements Document.

Letter from W. R. Sugnet, EPRI, to NRC, forwarding proprietary information on ALWR seismic design evaluation program. Enclosures no longer withheld per

March 29, 1991, letter from EPRI.

Letter from C. L. Miller, NRC, to EPRI, forwarding DSER on Chapters $6,7,8,9,12$, and 13 of Volume II of ALWR Utility Requirements Document.

Letter from T. J. Kenyon, NRC, to EPRI, requesting additional information on Volumes II and III of ALWR Utility Requirements Document regarding quality assurance. Document no longer withheld per March 29, 1991 letter from EPRI.

Letter from E. E. Kintner, EPRI, to NRC, forwarding response to request for additional information on reactor vessel level instrumentation system and addressing concerns related to Volume II of ALWR Utility Requirements Document. Response no longer withheld per March 29, 1991 letter from EPRI.

Letter from W. R. Sugnet, EPRI, to NRC, forwarding comparison between Volumes II, and III of ALWR Utility Requirements Document. Enclosures on longer withheld per March 29, 1991 letter from EPRI.

Letter from $W$. R. Sugnet, EPRI, to NRC, forwarding data base for tracking open issues in DSER for Chapters 1-5 of Volume II of ALWR Utility Requirements Document. Enclosure no longer withheld per March 29, 1991 letter from EPRI.

Report by Jack R. Benjamin and Associates, Inc., "Advanced LWR Seismic Design and Evaluation Program." Report no longer withheld per March 29, 1991 letter from EPRI.

Letter from W. R. Sugnet, EPRI, to NRC, forwarding Revision 1 of "Development of Seismic Hazard Input for Advanced LWR Seismic PRA," in response to NRC request at meeting on January 14, 1991.

Letter from D. Crutchfield, NRC, to EPRI, providing preliminary views on Revision 0 of Volume III of ALWR 
Febriary 7, 1991

Febriary 7, 1991

Febriary 22, 1991

Febriary 28, 1991

Febriary 28, 1991

Febriary 28, 199

Marct 1, 1991

March 1, 1991

March 1, 1991
Utility Requirements Document regarding criteria to be used in design for combustible gas control. Document no longer withheld per march 29, 1991 letter from EPRI.

Letter from T. H. Boyce, NRC, to EPRI, providing summary of January 14, 1991 meeting with EPRI in Rockville, Maryland, regarding seismic issues for ALWR Utility Requirements Document. Summary no longer withheld per March 29, 1991 letter from EPRI.

Letter from E. E. Kintner, EPRI, to NRC, forwarding responses to questions raised at meeting on November 29 and 30, 1990. Numbering scheme for responses also enclosed. Responses no longer withheld per March 29, 1991 letter from EPRI.

Letter from $W$. R. Sugnet, EPRI, to NRC, forwarding EPRI NP-5159, "Guidelines for Specifying Integrated ComputerAided Engineered Applications for Electric Power Plants," and EPRI NP-5639, "Guidelines for Piping System Reconciliation (NCIG-05, Revision 1)."

Letter from $W$. R. Sugnet, EPRI, to NRC, forwarding Sections 1-5 of Chapter 1, Volume II of ALWR Utility Requirements Document to propose level of information to be witheld from public disclosure. Document no longer withheld per March 29, 1991 letter from EPRI.

Letter from J. H. Wilson, NRC, to EPRI, requesting additional information on Volume III of ALWR Utility Requirements Document.

Report by M. W. McCann, Jack R. Benjamin and Associates, Inc., Revision 1 of "Development of Seismic Hazard Input for Advanced LWR Seismic PRA."

Letter from J. H. Wilson, NRC, to EPRI, requesting additional information Volume III of ALWR Utility Requirements Document regarding quality assurance. Document no longer withheld per March 29, 1991 letter from EPRI.

Letter from J. H. Wilson, NRC, to EPRI, requesting additional information on Volume III of ALWR Utility Requirements Document regarding physical security and safeguards requirements. Document no longer proprietary per March 29, 1991 letter from EPRI.

Letter from J. H. Wilson, NRC, to EPRI, requesting additional information on Volume III of ALWR Utility Requirements Document regarding plant systems. Document no longer withheld per March 29, 1991 letter from EPRI. 
March 1, 1991

March 1, 1991

March 1, 1991

March 1, 1991

March 8, 1991

March 14, 1991

March 15, 1991

March 15, 1991

March 19, 1991

March 28, 1991
Letter from J. H. Wilson, NRC, to EPRI, requesting additional information on ALWR Utility Requirements Document regarding radiation protection and health physics. Document no longer withheld per March 29, 1991 letter from EPRI.

Letter from J. H. Wilson, NRC, to EPRI, providing summary of February 11 and 12, 1991, meetings with EPRI in Rockville, Maryland, to discuss NRC staff review of Volume II of ALWR Utility Requirements Document. List of attendees enclosed.

Letter from J. H. Wilson, NRC, to EPRI, correcting summary of February 11 and 12, 1991, meetings in Rockville, Maryland, to discuss NRC staff review of Volume II of ALWR Utility Requirements Document.

Letter from W. R. Sugnet, EPRI, to NRC, forwarding industry list of technical issues central to design of ALWR passive plants.

Letter from J. H. Wilson, NRC, to EPRI, requesting additional information on Volume III of ALWR Utility Requirements Document regarding reactor systems. Document no longer withheld per March 29, 1991 letter from EPRI.

Letter from E. E. Kintner, EPRI, to NRC, providing perspective of progress on work on ALWR Utility Requirements Document.

Letter from E. E. Kintner, EPRI, to NRC, forwarding response to January 25,1991 , request for additional information on quality assurance. Response no longer withheld per March 29, 1991 letter from EPRI.

Letter from E. E. Kintner, EPRI, to NRC, forwarding response to requests for additional information on quality assurance. Enclosure no longer withheld per March 29, 1991 letter from EPRI.

Letter from T. H. Boyce, NRC, to EPRI, providing summary of March 5 and 6, 1991, meetings with Combustion Engineering and EPRI in Rockville, Maryland, regarding NRC staff review of Volume II of ALWR Utility Requirements Document. List of attendees and agenda enclosed.

Letter from T. H. Boyce, NRC, to EPRI, providing summary of March 28, 1991, meeting with EPRI in Rockville, Maryland, to discuss NRC staff review of Volume II of ALWR Utility Requirements Document. 
Apri 3, 1991

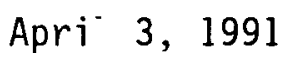

Aprii 5, 1991

Apri1 8, 1991

April 17, 1991

Apri1 17, 1991

April 22, 1991

April 24, 1991

Apri1 24, 1991

April 25, 1991

April 25, 1991
Letter from C. L. Miller, NRC, to EPRI, forwarding DSER on Chapter 11 of Volume II of ALWR Utility Requirements Document.

Letter from J. H. Wilson, NRC, to EPRI, requesting additional information on Volume III of ALWR Utility Requirements Document. Information needed to complete review of design criteria addressed during review of Chapter 9, "Site Support System."

Letter from J. H. Wilson, NRC, to EPRI, concluding that regulations and guidance not applicable to design requirements should be added to "applicable" list in Appendix B to Chapter 1 of ALWR Utility Requirements Document. Information given in October 29, 1990, letter should be added to next revision of document.

Letter from J. H. Wilson, NRC, to EPRI, requesting EPRI's position on changes to criteria in Volume III of ALWR Utility Requirements Document that apply to evolutionary designs.

Letter from J. H. Wilson, NRC, to EPRI, requesting information on Volume III of ALWR Utility Requirements Document regarding human factors.

Letter from J. H. Wilson, NRC, to EPRI, requesting additional information on Volume III of ALWR Utility Requirements Document regarding safeguards.

Letter from J. H. Wilson, NRC, to EPRI, requesting additional information on Volume III of ALWR Utility Requirements Document regarding reactor systems.

Letter from K. M. Carr, NRC, to EPRI, responding to March 14, 1991, letter noting significant progress made in last year on ALWR Utility Requirements Document. Agreed that review of advanced passive reactors presented different kind of challenge.

Letter from J. H. Wilson, NRC, to EPRI, requesting additional information on Volume III of ALWR Utility Requirements Document regarding structural engineering concerns.

Letter from J. H. Wilson, NRC, to EPRI, requesting additional information on Volume III of ALWR Utility Requirements Document regarding materials and chemcial engineering concerns.

Letter from E. E. Kintner, EPRI, to NRC, forwarding response to requests for additional information on 
Apri1 26, 1991

Apri1 30, 1991

Apri1 30, 1991

Apri1 30, 1991

May 6, 1991

May 6, 1991

May 8, 1991

May 8, 1991

May 8, 1991

May 9, 1991
Chapters 4 and 7 of Volume III of ALWR Utility Requirements Document regarding reactivity physics, fuel, and fuel storage criticality.

Letter from E. E. Kintner, EPRI, to NRC, forwarding Revision 2 of Volume II and Revision 1 of Volume III of ALWR Utility Requirements Document in response to NRC concerns regarding quality assurances, human factors, generic and unresolved safety issues, and open issues in DSERs. Changes resulting from elimination of operatingbasis earthquake also included.

Letter from EPRI, to NRC, submitting copies of Revision 1 of Volume II of ALWR Utility Requirements Document; and Chapter 1 and Appendix B to Chapter 1 updated through Revision 2.

Letter from EPRI, to NRC, transmitting revised pages issued as Revision 2 of Volume II and Revision 1 of Volume III of ALWR Utility Requirements Document.

Letter from EPRI, to NRC, transmitting "Position Paper on Standardization."

Letter from J. H. Wilson, NRC, to EPRI, requesting additional information on Volume III of ALWR Utility Requirements Document regarding materials engineering concerns.

Letter from D. Crutchfield, NRC, to EPRI, clarifying issues discussed in SECY-90-016.

Letter from E. E. Kintner, EPRI, to NRC, forwarding response to April 8, 1991, letter regarding consistent changes to Volumes II and III of ALWR Utility Requirements Document.

Letter from E. E. Kintner, EPRI, to NRC, forwarding response to March 8,1991 , request for additional information on Chapter 4 of Volume III of ALWR Utility Requirements Document.

Letter from E. E. Kintner, EPRI, to NRC, forwarding response to April 5, 1991, letter regarding regulations and guidance not applicable to ALWR design requirements.

Letter from E. E. Kintner, EPRI, to NRC, forwarding report describing plant containment performance criteria for evolutionary plant and rationale for their selection. Information provided technical support for Volume II of ALWR Utility Requirements Document. 
May S, 1991

May 13, 1991

May 13, 1991

May 13, 1991

May 13, 1991

May 13, 1991

May 17, 1991

May 17, 1991

May 17, 1991

May 1\%, 1991
Letter from E. E. Kintner, EPRI, to NRC, forwarding matrix approach to containment performance criteria for evolutionary plants and rationale for their selection.

Letter from E. E. Kintner, EPRI, to NRC, forwarding response to March 1, 1991, request for additional information on Volume III of ALWR Utility Requirements Document regarding measures to be taken to prevent high operational and post-shutdown radiation levels in reactor coolant system piping.

Letter from E. E. Kintner, EPRI, to NRC, forwarding response to February 28, 1991, request for additional information on Volume III of ALWR Utility Requirements Document regarding system reliability, quality assurance, and seismic qualification or capability of non-safetygrade active systems.

Letter from E. E. Kintner, EPRI, to NRC, forwarding response to March 1, 1991, request for additional information on Volume III of ALWR Utility Requirements Document regarding resolution of GSI A-29 for advanced reactors.

Letter from E. E. Kintner, EPRI, to NRC, forwarding partial response to March 1,1991 , request for additional information on Volume II of ALWR Utility Requirements regarding fire protection.

Letter from EPRI, to NRC forwarding response to March 1 , 1991, request for additional information on Volume III of ALWR Utility Requirements Document.

Letter from J. H. Wilson, NRC, to EPRI, requesting additional information on Volume III of ALWR Requirements Document regarding mechanical engineering concerns.

Letter from J. H. Wilson, NRC, to EPRI, requesting additional information on Volume III of ALWR Utility Requirements Document regarding instrumentation and controls.

Letter from J. H. Wilson, NRC, to EPRI, forwarding page 15 omitted from Apri1 22, 1991, request for additional information regarding review of Chapter 5 of Volume III of ALWR Utility Requirements Document.

Letter from J. H. Wilson, NRC, to EPRI, requesting additional information on Volume III of ALWR Utility Requirements Document regarding reactor systems. 
May 17, 1991

May 22, 1991

May 22, 1991

May 22, 1991

June 5,1991

June 13, 1991

June 24,1991

JuTy 1,1991

Ju1y 1,1991

Ju1y 2, 1991
Letter from J. H. Wilson, NRC, to EPRI, requesting additional information on Volume III of ALWR Utility Requirements Document submitted on September 7, 1990 regarding safeguards considerations.

Letter from E. E. Kintner, EPRI, to NRC, forwarding response to request for additional information on Volume III of ALWR Utility Requirements Document regarding $\mathrm{plant}$ systems.

Letter from E. E. Kintner, EPRI, to NRC, forwarding response to request for additional information on Volume III of ALWR Requirements Document regarding radiation protection.

Letter from G. Bockhold, EPRI, to NRC, forwarding updated open issues tracking system for Chapters 1-9, 11 , and 12 of Volume II of ALWR Utility Requirements Document.

Letter from J. H. Wilson, NRC, to EPRI, requesting additional information on reactor systems to complete review of Volume II of ALWR Utility Requirements Document.

Letter from E. E. Kintner, EPRI, to NRC, forwarding response to April 17, 1991, request for additional information on Volume III of ALWR Utility Requirements Document regarding human factors.

Letter from E. E. Kintner, EPRI, to NRC, forwarding responses to April 3 and 17,1991 , requests for additional information on ALWR Utility Requirements Document regarding safeguards concerns.

Letter from E. E. Kintner, EPRI, to NRC, forwarding response to requests for additional information on Volume III of ALWR Utility Requirements Document regarding compliance of leak-before-break methodology with acceptance criteria in statement of considerations for final rule, General Design Criterion 4 of Appendix A to 10 CFR Part 50 .

Letter from E. E. Kintner, EPRI, to NRC, forward response to April 22, 1991, request for additional information on Section 6.2.2 of Chapter 1 of Volume III of ALWR Requirements Document regarding reliability requirements for non-safety critical systems.

Letter from E. E. Kintner, EPRI, to NRC, forwarding response to Apri1 24, 1991, request for additional information on Volume III of ALWR Utility Requirements Document regarding safety-margin basis requirements. 
July 8,1991

July 22, 1991

Ju1y 22, 1991

July 22, 1991

August 1, 1991

August 1,1991

August 1, 1991

August 12, 1991

August 16, 1991

August 19, 1991

August 19, 1991
Letter from E. E. Kintner, EPRI, to NRC, forwarding response to May 17, 1991, request for additional information on Volume III of ALWR Utility Requirements Document regarding emergency planning.

Letter from E. E. Kintner, EPRI, to NRC, forwarding response to May 17, 1991, request for additional information on Volume III of ALWR Utility Requirements Document regarding methodology for dedicating commercial software for designing safety-related systems.

Letter from E. E. Kintner, EPRI, to NRC, forwarding response to May 17, 1991, request for additional information on Volume III of ALWR Utility Requirements Document regarding site security interfaces in plant security systems and key-locked controls.

Letter from E. E. Kintner, EPRI, to NRC, forwarding response to May 17, 1991, request for additional information on Volume III of ALWR Utility Requirements Document regarding safes, single-action valves, security barriers, and intrusion detection systems.

Letter from E. E. Kintner, EPRI, to NRC, forwarding response to April 22, 1991, request for additional information on Volume III of ALWR Utility Requirements Document regarding reactor systems.

Letter from E. E. Kintner, EPRI, to NRC, forwarding response to May 17, 1991, request for additional information on Volume III of ALWR Utility Requirements Document regarding mechanical engineering regarding material and chemical engineering concerns.

Letter from E. E. Kintner, EPRI, to NRC, forwarding final response to May 17, 1991, request for additional information Volume III of ALWR Utility Requirements Document.

Letter from E. E. Kintner, EPRI, to NRC, forwarding response to June 5, 1991, request for additional information on Volume II of ALWR Utility Requirements Document regarding reactor systems.

Letter from J. H. Wilson, NRC, to EPRI, requesting additional information on Volume III of ALWR Utility Requirements Document.

Letter from J. H. Wilson, NRC, to EPRI, requesting additional information on Volume III of ALWR Utility Requirements Document regarding human factors.

Letter from J. H. Wilson, NRC, to EPRI, requesting additional information on Volume III of ALWR Utility Requirements Document regarding safeguards. 
August 20, 1991

August 29, 1991

September 5, 1991

September 5, 1991

September 6, 1991

September 11,1991

September 11, 1991

September 23, 1991

October 1, 1991

October 2, 1991

October 2, 1991

October 3, 1991
Letter from T. J. Kenyon, NRC, to EPRI, providing summary of July 17, 1991, meeting to discuss effects of changes in source term on ALWR designs.

Letter from D. Crutchfield, NRC, to EPRI, requesting additional information on Volume III of ALWR Utility Requirements Document regarding Question 210.40.

Letter from J. H. Wilson, NRC, to EPRI, requesting additional information on Volume II of ALWR Utility Requirements Document regarding shutdown risks.

Letter from J. H. Wilson, NRC, to EPRI, requesting additional information on Volume III of ALWR Utility Requirements Document regarding shutdown risks.

Letter from J. H. Wilson, NRC, to EPRI, transmitting open issues from staff review of Appendix A to Chapter 1 of Volume II of ALWR Utility Requirements Document.

Letter from D. E. Leaver, Tenera, L.P. (formerly Tenera Corporation), to NRC, providing additional information for NRC consideration on several ALWR source term matters that came up at August 1991 meeting.

Letter from J. H. Wilson, NRC, to EPRI, requesting additional information on Volume III of ALWR Utility Requirements Document regarding unresolved and generic safety issues.

Letter from J. H. Wilson, NRC, to EPRI, requesting additional information on Appendix $A$ to Chapter 1 of Volume III of ALWR Utility Requirements Document.

Letter from G. Bockhold, EPRI, to NRC, forwarding Volumes II and III of ALWR Utility Requirements Document consisting of hand-marked page changes in accordance with NRC request.

Letter from J. H. Wilson, NRC, to EPRI, summarizing August 27,1991 , meeting with utilities in Rockville, Maryland, regarding development of updated source term for LWRs.

Letter from J. H. Wilson, NRC, to EPRI, summarizing August 14 and 15, 1991, meetings with EPRI in Rockville, Maryland, to discuss issues associated with staff review of Volume III ALWR Utility Requirements Document.

Letter from R. Chambers, Idaho National Engineering Laboratory, to NRC, forwarding two copies of Advanced Reactor Severe Accident Program report "Interim External Events Integration for EPRI Advanced LWR Requirements Document 
October 8, 1991

October 9, 1991

Octolier 10, 1991

Octolier 10, 1991

Octotier 17, 1991

Octotier 23, 1991

Octoter 30, 1991

Noveniber 4, 1991

November 4, 1991

Novenber 6, 1991
WBS 4.3.3," DOE-ID-10227, by D. G. Harrison in response to request by $J$. D. Trotter of EPRI to support review of Project 669 .

Letter from R. C. Pierson, NRC, to EPRI, forwarding DSER on Chapter 10 of Volume II of ALWR Utility Requirements Document.

Letter from E. E. Kintner, EPRI, to NRC, forwarding response to August 19, 1991, request for additional information on Volume III of ALWR Utility Requirements Document. Battery rooms to be locked and alarmed, and isolation zone lighting to be designed to permit observation.

Letter from J. H. Wilson, NRC, to EPRI, requesting additional information on Volume III of ALWR Utility Requirements Document submitted on September 7, 1990, regarding the reliability assurance program.

Letter from J. H. Wilson, NRC, to EPRI, forwarding open issues from review of Section 6 of Chapter 1 of Volume II of ALWR Utility Requirements Document.

Letter from G. Bockhold, EPRI, to EPRI, forwarding response to questions raised during teleconference regarding ALWR seismic hazard curve.

Letter from J. H. Wilson, NRC, to EPRI, forwarding corrections for pages 4-10 and 4-11 of DSER on Chapter 10 of Volume II of ALWR Utility Requirements Document transmitted by letter dated October 8, 1991.

Letter from J. H. Wilson, NRC, to EPRI, summarizing September 26, 1991, meeting with EPRI in Rockville, Maryland, to present results of research by NRC and contractors concerning development of updated source term. List of attendees provided.

Letter from R. C. Pierson, NRC, to EPRI, forwarding DSER on Appendix A to Chapter 1 of Volume II of ALWR Utility Requirements Document. Open issues required resolution.

Letter from G. Bockhold, EPRI, to NRC, forwarding information regarding errors and resolutions in response to request for additional information on ALWR Utility Requirements Document.

Letter from E. E. Kintner, EPRI, to NRC, forwarding response to August 29, 1991 , request for additiona 1 information on Volume III of ALWR Utility Requirements Document regarding mechanical engineering concerns. 
November 15, 1991

November 20, 1991

November 25, 1991

November 27,1991

December 2, 1991

December 6, 1991

December 10, 1991

December 16, 1991

December 18, 1991

December 20, 1991
Letter from E. E. Kintner, EPRI, to NRC, forwarding response to August 19,1991 , request for additional information on Volume III of ALWR Utility Requirements Document regarding human factors.

Letter from E. E. Kintner, EPRI, to NRC, forwarding response to September 11,1991 , request for additional information on Volume III of ALWR Utility Requirements Document regarding unresolved and generic safety issues.

Letter from E. E. Kintner, EPRI, to NRC, forwarding Revision 3 of Volume II of ALWR Utility Requirements Document.

Letter from E. E. Kintner and J. J. Taylor, EPRI, to NRC, proposing agenda of meetings at senior levels of NRC staff and Utility Steering Committee to discuss remaining generic safety issues in ALWR Utility Requirements Document as discussed at workshop on November 4 and 5, 1991.

Letter from E. E. Kintner, EPRI, to NRC, forwarding response to September 5, 1991, request for additional information on Volume II of ALWR Utility Requirements Document regarding shutdown risk.

Letter from E.PRI, to NRC, forwarding ALWR positions on central issues pertaining to evolutionary plant identified during July 1991 meeting with NRC. Issues included containment performance, core debris coolability, and seismic hazard.

Letter from J. D. Trotter, EPRI, to NRC, forwarding penand-ink changes to Chapters 5, 6, 9, 10, and 11 of Volume II of ALWR Utility Requirements Document regarding security and suggesting working-level meeting during week of January 6, 1992, to resolve any outstanding concerns.

Letter from E. E. Kintner, EPRI, to NRC, forwarding response to September 5, 1991, request for additional information on Chapters 4 and 5 of Volume II of ALWR Utility Requirements Document regarding scope of PRA for operating conditions when plant is at power and general initiating events.

Letter from G. Bockhold, EPRI, to NRC, advising that modification of Figure 12.3-1 in Chapter 12 of Volume II of ALWR Utility Requirements Document was inadvertently omitted from list of changes submitted to NRC in June and October 1991.

Letter from D. Crutchfield, NRC, to EPRI, identifying issues pertaining to evolutionary and passive plant designs. Information provided to initiate discussion of approaches to resolving issues. 
December 20, 1991 Letter from J. D. Trotter, EPRI, to NRC, forwarding summary of technical rationale by $C$. Negin regarding high-efficiency particulate air filters in radioactive waste off-gas system.

December 21, 1991 Letter from J. D. Trotter, EPRI, to NRC, forwarding proposed minor revisions of ALWR Utility Requirements Document addressing open issues pertaining to reactor pressure vessel materials.

December 26, 1991 Letter from D. Crutchfield, NRC, to EPRI, discussing preparation of final SER on Volume II of ALWR Utility Requirements Documents and requesting that EPRI submit al1 responses and positions by January 31, 1992, so that staff could complete its technical evaluations.

January 9, 1992

Letter from E. E. Kintner, EPRI, to NRC, forwarding response to October 10,1991 , request for additional information on open issues resulting from NRC review of Section 6 of Chapter 1 of Volume II of ALWR Utility Requirements Document.

January 9, 1992 Letter from E. E. Kintner, EPRI, to NRC, forwarding response to October 10, 1991, request for additional information on Volume III of ALWR Requirements Document.

January 10, 1992 Letter from E. E. Kintner, EPRI, to NRC, forwarding response to August 16, 1991, request for additional information on Volume III of ALWR Utility Requirements Document regarding electrical systems.

January 10, 1992 Letter from G. Bockhold, EPRI, to NRC, forwarding response to May 17, 1991, request for additional information on Volume III of ALWR Utility Requirements Document regarding core support structures because initial response dated August 1, 1991, was inappropriate.

January 22, 1992 Letter from D. Crutchfield, NRC, to EPRI, discussing January 30,1992 , meeting with EPRI in Palo Alto, California, concerning resolution of policy and technical issues associated with ALWR Utility Requirements Document .

January 24, 1992 Letter from J. H. Wilson, NRC, to EPRI, summarizing January 8, 1992, meeting with EPRI in Rockville, Maryland, to discuss EPRI-proposed changes to security requirements.

January 24, 1992 Letter from E. E. Kintner, EPRI, to NRC, forwarding response to September 23, 1991, request additional information on Appendix A to Chapter 1 of Volume III of ALWR Utility Requirements Document. 
January 24, 1992

January 24, 1992

January 24, 1992

January 28, 1992

February 3, 1992

February 3, 1992

February 4, 1992

February 10, 1992

February 11, 1992
Letter from G. Bockhold, EPRI, to NRC, forwarding responses to open and confirmatory issues in DSER on Appendix A to Chapter 1 of Volume II of ALWR Utility Requirements Document. Enclosure included both data base summaries for each issue and markups of pages in Volume II pages.

Letter from E. E. Kintner, EPRI, to NRC, submitting changes to Chapters $5,6,9,10$, and 11 of Volume II of ALWR Utility Requirements Document that dealt with safeguards-related requirements. Changes should be considered in final SER on Volume II.

Letter from G. Bockhold, EPRI, to NRC, forwarding responses to three issues in DSER on Chapter 11 of Volume II of ALWR Utility Requirements Document. Enclosure includes both data base summaries for each issue and markups of pages in Volume II.

Letter from G. Bockhold, EPRI, to NRC, forwarding first part of responses to open and confirmatory issues ( 99 of 126 issues) in DSER on Chapter 10 of Volume II of ALWR Utility Requirements Document. Minor proposed changes to be reflected in Revision 4 of Volume II.

Letter from G. Bockhold, EPRI, to NRC, forwarding second part of responses to open and confirmatory issues in DSER on Chapter 10 of Volume II of ALWR Utility Requirements Document and stating that responses had been given for all but four of the issues. Responses to remaining four issues to be provided later this month.

Letter from G. Bockhold, EPRI, to NRC, forwarding changes to Volume II of ALWR Utility Requirements Document that addressed DSER open and confirmatory issues or other concerns. Changes to be incorporated into Revision 4 of Volume II.

Letter from G. Bockhold, EPRI, to NRC, forwarding proposal for maintenance feed to top-tier electrical bus action.

Letter from T. U. Marston, EPRI, to NRC, suggesting staff-level meetings be held in late February and early March of 1992 to expedite quality closure of DSER issues pertaining to chapters on man-machine interface systems and PRA in Volume II of Utility Requirements Document.

Letter from J. D. Trotter, EPRI, to NRC, discussing miscellaneous items for Project 669 including resolution of steam generator tube ruptures by increasing design pressure. 
February 18, 1992

March 2, 1992

March 3, 1992

March 3, 1992

March 9, 1992

March 10, 1992

March 19, 1992

March 19, 1992

March 30, 1992

March 31, 1992
Letter from $G$. Bockhold, EPRI, to NRC, forwarding responses to four open issues in DSER on Chapter 10 of Volume II of ALWR Utility Requirements Document in response to October 10, 1991, request for additional information and containing both data base and road-map summaries for each issue and markups of pages in Volume II.

Letter from D. Crutchfield, NRC, to EPRI, forwarding - draft Commission paper describing major technical and policy issues on evolutionary and passive plant designs. Positions supersede those in February 20, 1991 letter.

Letter from T. J. Kenyon, NRC, to EPRI, summarizing January 30, 1992 senior management meeting with EPRI and nuclear industry representatives on technical issues for evolutionary and passive ALWRs. List of attendees and presentations enclosed.

Letter from G. Bockhold, EPRI, to NRC, forwarding February 1992 status report. Significant progress apparent in area of policy issues.

Letter from G. Bockhold, EPRI, to NRC, forwarding proposed changes to Chapter 1, Append ix B to Chapter 1, and Chapters 10 and 11 of Volume II of ALWR Utility Requirements Document.

Letter from T. J. Kenyon, NRC, to EPRI, issuing errata to summary of senior management meeting on January 30, 1992 on technical issues for evolutionary and passive ALWRs.

Letter from J. D. Trotter, EPRI, to NRC, forwarding final draft of position paper for passive plant system classification and requirements.

Letter from E. E. Kintner, EPRI, to NRC, forwarding position paper on passive plant system classification and requirements,

Letter from G. Bockhold, EPRI, to NRC, forwarding changes to Volume II of ALWR Utility Requirements Document per continuing discussions with NRC.

Letter from G. Bockhold, EPRI, to NRC, submitting changes to Chapter 11 of ALWR Utility Requirements Document in response to NRC concerns associated with electrical distribution policy issue.

Letter from G. Bockhold, EPRI, to NRC, forwarding changes to Volume III of ALWR Utility Requirements Document addressing open issues on performance requirement for turbine exhaust boot and design of radial and thrust bearings. 
Apri1 3, 1992

April 7, 1992

Apri1 9, 1992

Apri1 9, 1992

April 9, 1992

April 17, 1992

Apri1 17, 1992

Apri1 24, 1992

April 30, 1992

May 1, 1992

May 5, 1992
Letter from G. Bockhold, EPRI, to NRC, forwarding comments on draft NUREG/CR-5747 "Estimate of Radionuclide Release Characteristics into Containment Under Severe Accident Conditions."

Letter from G. Bockhold, EPRI, to NRC, submitting response to NRC request for additional information on second source of power to non-safety loads required exclusively for unit operation as discussed in Sections 3.3 and 4.2 of Chapter 11 of DSER.

Letter from G. Bockhold, EPRI, to NRC, on diversity against common-mode software failures. Listed elements provided in Chapter 10 of ALWR Utility Requirements Document.

Letter from W. Borchardt, NRC, to EPRI, summarizing March 27, 1992 meeting with EPRI in Denver, Colorado on major issues resulting from NRC review of ALWR Utility Requirements Document for evolutionary and passive designs. List of attendees, meeting agenda handouts, and slides enclosed.

Letter from G. Bockhold, EPRI, to NRC, submitting summary of methods \& assumptions used in development of ALWR 80th percentile meteorological database.

Letter from G. Bockhold, EPRI, to NRC, submitting changes to Chapter 3 of Volume II of ALWR Utility Requirements Document concerning testability of third feedwater isolation valve in bwrs. Similar change will be made to Volume III.

Letter from E. E. Kintner, EPRI, to NRC, forwarding Revision 4 to Volume II of ALWR Utility Requirements Document.

Letter from D. Crutchfield, NRC, to EPRI, forwarding DSER on Volume III of ALWR Utility Requirements Document.

Letter from D. Crutchfield, NRC, to EPRI, discussing topics under consideration for inclusion in Commission paper to discuss additional issues on future reactor designs.

Letter from G. Bockhold, EPRI, to NRC, forwarding response to open issue on the use of physically-based source term on Volume II of the ALWR Utility Requirements Document.

Letter from G. Bockhold, EPRI, to NRC, forwarding modifications to ALWR Utility Requirements Document to address general concern of. NRC on vulnerability of ALWRs during shutdown \& low power operation. 
May E, 1992

May \&, 1992

May 13,1992

May 15, 1992

May 28, 1992

May 26, 1992

June 4, 1992

June 15, 1992

June 23, 1992

July 2, 1992

July 6, 1992

July 6, 1992
Letter from G. Bockhold, EPRI, to NRC, forwarding draft of PWR and BWR passive plant system classification. Enclosure submitted to facilitate preparations for May 14, 1992 meeting on regulatory treatment of nonsafety systems.

Letter from G. Bockhold, EPRI, to NRC, forwarding EPRI's draft positions on additional technical and policy issues on passive and evolutionary plant designs in parallel with Utility Steering Committee review.

Letter from E. E. Kintner, EPRI, to NRC, forwarding Revision 3 to Chapters 1-13 of Volume III of the ALWR Utility Requirements Document.

Letter from D. Crutchfield, NRC, to EPRI, forwarding draft of SER on Volume II of ALWR Utility Requirements Document.

Letter from T. J. Kenyon, NRC, to EPRI, summarizing meeting with EPRI on May 6, 1992 on in-containment fission product removal mechanisms for evolutionary and passive plant designs.

Letter from T. J. Kenyon, NRC, to EPRI, summarizing meeting with EPRI on March 20, 1992 on EPRI's initial work on reliability-based technical specifications for passive ALWRs. List of attendees and EPRI presentation included.

Letter from E. E. Kintner, EPRI, to NRC, responding to February 27, 1992 letter on major technical and policy issues for evolutionary and passive plant designs

Letter from G. Bockhold, EPRI, to NRC, forwarding April and May 1992 status report

Letter from D. Crutchfield, NRC, to EPRI, discussing EPRI-proposed optimization subject on simplification of off-site emergency planning for ALWRs using passive safety systems.

Letter for G. Bockhold, EPRI, to NRC, forwarding data base for issues identified on Chapters 2-10 of Volume III of the ALWR Utility Requirements Document.

Letter from G. Bockhold, EPRI, to NRC, forwarding discussion of term 'decommissioning' as term relates to ALWR Utility Requirements Document.

Letter from D. Crutchfield, NRC, to EPRI, forwarding draft commission paper, "Design Certification and Licensing Policy Issues Pertaining to Passive and Evolutionary Advanced Light Water Reactor designs." 
July 17, 1992

Letter from G. Bockhold, EPRI, to NRC, forwarding revised data base for issues on Chapter 9 of Volume III of the ALWR Utility Requirements Document. Issues include balance-of-plant fire protection program, independence of ventilation system inside containment, and requirements for smoke removal capability.

JuTy 7,1992

Letter from T.G. Hiltz, NRC, to EPRI, summarizing meeting with EPRI on June 11, 1992 on generic system classification, reliability-based technical specifications, and shutdown risk considerations for ALWRs.

August 3, 1992

Letter from G. Bockhold, EPRI, to NRC, forwarding supporting information on charcoal filters per teleconference with NRC. 
APPENDIX B

\section{REFERENCES}

Atomi: Industrial Forum (AIF), AIF/NESP-020, "Compendium of Design Features to Reduc? Occupational Radiation Exposure at Nuclear Power Plants."

---, AIF Study, 6.4-12.

Committee on the Biological Effects of Ionizing Radiation, "The Effect on Population of Exposure to Low Level of Ionizing Radiation," July 1980

Electric Power Research Institute (EPRI), EPRI NP-309, "Human Factors Review of Nuilear Power Plant Control Room Design."

---, :PRI NP-1081, "Refueling Outage Water Clarity Improvement Study."

---, EPRI NP-1982, "Evaluation of Proposed Control Room Improvements Through Analysis of Critical Operator Actions."

---, IPRI NP-2294, "Guide to Design of Secondary Systems and Their Components To Millimize Oxygen-Induced Corrosion."

---, EPRI NP-2360, "Human Factors Methods for Assessing and Enhancing Power Plant Maintainability."

---, I:PRI NP-2411, "Human Engineering Guide for Enhancing Nuclear Control Room."

--, IEPRI NP-2777.

---, I:PRI NP-3448, "A Procedure for Reviewing and Improving Power Plant Alarm Systens."

---, I:PRI NP-3659, "Human Factors Guide for Nuclear Power Plant Control Room Development."

---, I:PRI NP-3701, "Computer-Generated Display Guidelines" (Volumes 1 and 2).

---, I:PRI NP-3784, "A Survey of the Literature on Low-Alloy Steel Fastener

Corro:ion in PWR Power Plants," J. S. Hall, December 1984.

---, I:PRI NP-4350, "Human Engineering Design Guidelines for Maintainability."

--- , I:PRI NP-4762-SR.

---, I:PRI NP-4947-SR, "BWR Hydrogen Water Chemistry Guidelines," 1987. 
---, EPRI NP-5067, "Good Bolting Practices, A Reference Manual for Nuclear Power Plant Maintenance Personnel, "Volume 1: "Large Bolt Manual, " 1987 and Volume 2: "Small Bolts and Threaded Fasteners," 1990.

---, EPRI NP-5159, "Guidelines for Specifying Integrated Computer-Aided Engineered Applications for Electric Power Plants."

---, EPRI NP-5283-SR-A, "Guidelines for Permanent BWR Hydrogen Water Chemistry Installations," September 1987.

---, EPRI NP-5479, "Application Guidelines for Check Valves in Nuclear Power Plants."

---, EPRI NP-5639, "Guidelines for Piping System Reconciliation (NCIG-05, Revision 1)."

---, EPRI NP-5652, "Guidance for the Utilization of Commercial Grade Items in Nuclear Safety Related Applications (NCIG-07)."

,--- EPRI NP-5693.

---, EPRI NP-5769, "Degradation and Failure of Bolting in Nuclear Power

Plants," R. E. Nicke11, Principal Investigator, Volumes 1 and 2, April 1988.

---, EPRI NP-5960, "PWR Primary Water Chemistry Guidelines," Revision 1.

---, EPRI NP-5989, "Effects of Control-Room Lighting on Operator Performance, A Pilot Empirical Study."

---, EPRI NP-6202, "Material Specification for Alloy X-750 in LWR Internal Components."

---, EPRI NP-6209, "Effective Plant Labeling and Coding."

---, EPRI NP-6316, "Guidelines for Threaded-Fastener Application in Nuclear Power Plants," Looram Engineering, Inc., July 1989.

---, EPRI NP-6433.

--- , EPRI NP-6559.

,--- EPRI NP-6628.

--- , EPRI NP-6748.

---, EPRI NP-7077, Revision 2.

---, EPRI NP-7183-SL, "SHARP 1, A Revised Systematic Human Action Reliability Procedure."

---, EPRI RP-2184-7.

--, EPRI RP-2705-7. 
---, EPRI TR-100259, "An Approach to the Analysis of Operator Actions in Probabilistic Risk Assessment," G. W. Parry, et al., Draft, November 1991.

Fauske and Associates, Inc., "Process for Evaluating Accident Management Capalsilities."

---, "Technical Support for the Hydrogen Control Requirement for the EPRI Advanced Light Water Reactor Requirements Document," June 1988.

Federal Guidelines on Dam Safety.

General Electric Company, NEDO-22155, "Generation and Mitigation of Combustible Mixtures in Inerted Mark I Containments."

---, NED0-31643 P (proprietary).

---, NEDO 31858.

Illuniination Engineering Society, "IES Lighting Handbook."

Naticinal Research Council, "Estimated Probabilities of Extreme Winds," 1988.

Nuclear Construction Issues Group (NCIG)-07, "Guidance for the Utilization of Commercial Grade Items in Nuclear Safety Related Applications."

---, NCIG-14 (EPRI NP-6628), "Procedure for Seismic Evaluation and Design of Sma11 Bore Piping," April 1990.

Nuclear Safety Analysis Center (NSAC), NSAC-39, "Verification and Validation for Safety Parameter Display Systems."

--- , NSAC-147, "Losses of Off-Site Power at U.S. Nuclear Power Plants; Through 1989."

Nuclear Utilities Management and Resource Council (NUMARC), NUMARC-87-00.

---, NUMARC Containment Integrity Working Group Report, February 1988.

---, "Process for Evaluating Accident Management Capabilities."

\section{INDUSTRY CODES AND STANDARDS}

American Concrete Institute (ACI), 318, "Building Code Requirements for Reinforced Concrete."

American National Standards Institute (ANSI), 10.4, "Guidel ines for the Verification and Validation of Scientific and Engineering Computer Programs for the Nuclear Industry," 1987.

,--- 35.1 .

---, A13.1-1981 (Reaffirmed 1985), "Scheme for the Identification of Piping Systems." 
---, A58.1-1982, "Minimum Design Loadings for Buildings and Other Structures." ,--- C96.1.

---, MC11.1-1976 (ISA-57.3), "Quality Standard for Instrument Air Systems."

---, N45.2.1, "Cleaning of Fluid Systems and Associated Components During Construction Phase of Nuclear Power Plants."

---, N45.2.2, "Packaging, Shipping, Receiving, Storage, and Handling of Items for Nuclear Power Plants."

---, N45.2.3, "Housekeeping During the Construction Phase of Nuclear Power Plants."

---, N45.4-1972, "Leakage Rate Testing of Containment Structures for Nuclear Reactors."

---, N101.2-1980, "Protective Coatings (Points) for Light Water Nuclear Reactor Containment Facilities," 1980.

---, N101.4-1972, "Quality Assurance for Protective Coatings Applied to Nuclear Facilities."

---, 235.1-1972, "Accident Prevention Signs, Specification for"

,--- Z86.1.

---, "Leak Rate Testing of the Containment Structures for Nuclear Reactors."

American National Standards Institute/American Concrete Institute (ANSI/ACI), 349, "Code Requirements for Nuclear Safety-Related Structures."

American National Standards Institute/American Institute of Steel Construction (ANSI/AISC), N-690, "Specification for the Design, Fabrication, and Erection of Steel Safety-Related Structures for Nuclear Facilities," Chicago, Illinois.

American National Standards Institute/American Nuclear Society (ANSI/ANS), 2.3, "Standard for Estimating Tornado and Extreme Wind Characteristics at Nuclear Power Sites," 1980.

---, 2.5-1984, "Standard for Determining Meteorological Information at Nuclear Power Sites."

---, 2.8-1981, "Standard for Determining Design Basis Flooding at Power Reactor Sites."

---, 2.12, "American Nuclear Society Guidelines for Combining Natural and ManMade Hazards at Power Reactor Sites."

---, 3.1, "Selection, Qualification and Training for Nuclear Power Plants."

,$-- 3.3-1988$. 
---, 18.1, "American National Standard Radiation Source Term for Normal Operation of Light Water Reactors."

---, 51.1, "Nuclear Safety Criteria for the Design of Stationary PWR Plants."

---, 52.1, "Nuclear Safety Criteria for the Design of Stationary BWR Plants."

---, 55.1, "Solid Radioactive Waste Processing Systems for Light Water Cooled Reactior Plants."

---, 55.4, "Gaseous Radioactive Waste Processing Systems for Light Water Reactior Plants."

,--- 55.6 , "Liquid Radioactive Waste Processing Systems for Light Water Reactior Plants."

,--- 56.2 , "Containment Isolation Provisions for Fluid Systems After a LOCA," 1976 and 1984.

,--- 56.7 .

---, 56.8, "Containment System Leakage Testing Requirements," 1987

---, 57.1, "Design Requirements for Light Water Reactor Fuel Handling Syste:ms."

---57.2 , "Design Requirements for Light Water Reactor Spent Fuel Storage Facilities at Nuclear Power Plants."

---, 57.3, "Design Requirements for New Fuel Storage Facilities at Light Water React or Plants."

,--- 58.1, "Plant Design Against Missiles."

--- 58.2, "Design Basis for Protection of Light Water Nuclear Power Plants Against the Effects of Pipe Rupture."

---, 58.8-1984, "Time Response Design Criteria for Safety Related Operator Actions at Nuclear Power Plants."

---, 58.9, "Single Failure Criteria for Light Water Reactor Safety-Related Fluid Systems."

---, 59.2-1985, "Safety Criteria for HVAC Systems Located Outside Primary Containment."

American National Standards Institute/American Society of Mechanical Engineers (ANSI/ASME), 3.3-1988.

---, AG-1, "Code on Nuclear Air and Gas Treatment," 1989.

---, B31.1, "Power Piping." 
-- , B.31.1, Appendix 2, "Non-Mandatory Rules for the Design of Safety Valve Installations."

---, N509, "Nuclear Power Plant Air Cleaning Units and Components," 1989.

---, N510, "Testing of Nuclear Air-Cleaning System," 1989.

---, NOG-1-1983, "Rules for Construction of Overhead and Gantry Cranes (Top Running Bridge, Multiple Girder)."

,-- NQA-1.

,$--- N Q A-2$.

-.-, OM-6, "Inservice Testing of Pumps."

---, OM-10, "Inservice Testing of Valves."

American National Standards Institute/Institute of Electrical and Electronics Engineers (ANSI/IEEE), 387, "IEEE Standard Criteria for Diesel Generator Units Applied as Standby Power Supplies for Nuclear Power Generating Stations."

---, 730, "Software Quality Assurance Plans."

$-\cdots, 828$.

---, 829, "Software Test Documentation."

---, 982.1-1988, "IEEE Standard Dictionary of Measures to Produce Reliable Software."

---, 982.2-1988, "IEEE Guide for the Use of IEEE Standard Dictionary of Measures To Produce Reliable Software."

---, 1012-1986, "IEEE Standard for Software V\&V Plan."

$---, 1042$.

---, 1063-1987, "Standard for Software Users Documentation."

---, ANS-7-4.3.2-1982, "Application Criteria for Programmable Digital Computer Systems in Safety Systems of Nuclear Power Generating Stations."

American Nuclear Society (ANS), 5.1, "Decay Heat Power in Light Water Reactors," La Grange Park, Illinois, October 1975 and October 1979.

---, 18.2-1973, "Nuclear Safety Criteria for the Design of Stationary Pressurized Water Reactor Plants."

American Society for Testing and Materials (ASTM), A262 Practice E, Modified Strauss Test.

---, A 708 Strauss Test. 
$---,+800$.

---, J 3803, "Standard Test Methods for Radiological Testing of Nuclear-Grade Gas-Prase Absorbents."

,--- J 3842.80 .

---, E-185-82, "Standard Recommended Practices for Surveillance Tests for Nuclear Reactor Vessels, " 1982.

$---, E-813$.

Amerizan Society of Civil Engineers (ASCE), 4-1986, "Seismic Analysis of Safety-Related Nuclear Structures and Commentary on Standard for Seismic Analysis of Safety-Related Nuclear Structures," September 1986.

---, 7-1988 (formerly ANSI A58.1).

Amerizan Society of Mechanical Engineers, Boiler and Pressure Vessel Code (ASME Code), Section III, "Nuclear Power Plant Components."

---, section III, Appendix II, Paragraph II-1430.

---, jection III, Appendix N.

---, Section III, Division 1, "Nuclear Power Plant Components, with Appendices."

---, Section III, Division 2, "Code for Concrete Reactor Vessels and Containments."

--- , jection III, Subsection CC-3720.

--- , jection III, Subsection NB/NC/ND-1100(a).

---, jection III, Subsection NCA-1140.

---, Section III, Subsection NF, "Component Supports."

---, Section III, Subsection NG, "Core Support Structures."

---, Section XI, "Rules for Inservice Inspection of Nuclear Power Plant Components."

---, Section XI, Subsection IWV 3421-3427(a).

-.-, lode Case $\mathrm{N}-397$.

---, Code Case N-411, "Alternative Damping Values for Seismic Analysis of Classies 1, 2, and 3 Piping Sections."

---, liode Case N-420, "Linear Energy Absorbing Supports for Subsection NF, Classıs 1, 2, and 3 Construction, Section III, Division 1." 
---, Code Case $\mathrm{N}-451$.

--- , Code Case $\mathrm{N}-462$.

---, NCA-1140.

---, NQA-2A, Part 2.7, "Quality Assurance Requirements of Computer Software for Nuclear Facility Applications."

,--- NQA 2.7 .

---, PTC 6, "Steam Turbines Performance Test Code."

---, PTC 6.1, "Alternative Procedure for Testing Steam Turbine."

,--- TDP-2.

Institute of Electrical and Electronics Engineers (IEEE), 279, "Criteria for Protection Systems for Nuclear Power Generating Stations."

---, 308-1980, "Criteria for Class IE Power Systems for Nuclear Power Generating Stations."

---, 323-1974, "IEEE Standard for Qualifying Class IE Equipment for Nuclear Power Generating Stations."

---, 334, "Standard for Type Tests of Continuous Duty Class 1E Motors for Nuclear Power Generating Stations."

---, 338-1977, "Criteria for the Periodic Testing of Nuclear Power Generating Station Safety Systems."

---, 344-1987, "Recommended Practices for Seismic Qualification of Class $1 \mathrm{E}$ Equipment for Nuclear Power Generating Stations."

---, 352, "Guide for General Principles of Reliability Analys is of Nuclear Power Generating Station Protection Systems."

---, 383, "Type Test of Class IE Electric Cables, Field Splices, and Connections for Nuclear Power Generating Stations."

---, 384, "IEEE Trial-Use Standard Criteria for Separation of Class 1E Equipment and Circuits," 1974.

,$--- 472-1974$.

$---, 484$.

$---, 519$.

---, 577, "Requirements for Reliability Analysis in the Design and Operation of Safety Systems for Nuclear Power Generating Stations." 
---, 603, "Trial-Use Standard Criteria for Safety Systems for Nuclear Power Generating Stations."

---, 741, "IEEE Standard Criteria for the Protection of Class 1E Power Systems and Equipment in Nuclear Power Generating Stations."

---, 765-1983, "IEEE Standard for Preferred Power Supply for Nuclear Power Generating Stations."

---, 828-1983, "IEEE Standard for Software Configuration Management Plans."

,--- 981.1 .

,--- 981.2 .

---, 982.2-1988, "IEEE Guide for the Use of IEEE Standard Dictionary of Measures To Produce Reliable Software."

---, 1008-1987, "IEEE Standard for Software Unit Testing."

,--- 1012 .

,--- 1042 .

---, 1050-1989, "IEEE Guide for Instrumentation and Control Grounding in Generating Stations."

--- , C37-90.1-1989.

---, C62.41-1980, "IEEE Guide for Surge Voltages in Low-Voltage AC Power Circuits."

---, P1023/D5, "Guide for the Application of Human Factors Engineering to Systems, Equipment and Facilities of Nuclear Power Generating Stations."

Instrument Society of America (ISA), 67.15, Draft RP 67.04, Part II,

"Metrodology for the Determination of Setpoints for Nuclear Safety-Related Instrumentation."

Insulated Power Cable Engineers Association (IPCEA), 5-61-402.

International Electrotechnical Commission (IEC), 880-1986, "Software for Compcters in the Safety Systems of Nuclear Power Stations."

Naticnal Electrical Code.

Naticnal Fire Protection Association (NFPA), 13, "Standard for the Installaticn of Sprinkler Systems."

$-\cdots, 70$.

---, 90A-1989, "Installation of Air Conditioning and Ventilating Systems."

---, 101, "Life Safety Code." 
---, 803, "Fire Protection for Light Water Nuclear Power Plants."

Tubular Heat Exchangers Manufacturers Association (THEMA), T-2.41.

Uniform Building Code.

U.S. Department of Defense (DOD), DOD-MIL-HDBK-217E, "Reliability Prediction of Electronic Equipment."

---, DOD-MIL-HDBK-263.

---, DOD-MIL-HDBK-338, "Electronic Reliability Design Handbook."

---, DOD-MIL-HDBK-472, "Maintainability Prediction."

---, DOD-STD-781, "Reliability Test Methods, Plans, and Environment of Engineering Development, Qualification, and Production."

---, DOD-STD-1399.

---, DOD-STD-1629A, "Procedures for Performing a Failure Modes Effects and Criticality Analysis." 
APPENDIX C

\section{LIST OF ABBREVIATIONS}

The following is a list of abbreviations used throughout this report and the DSER

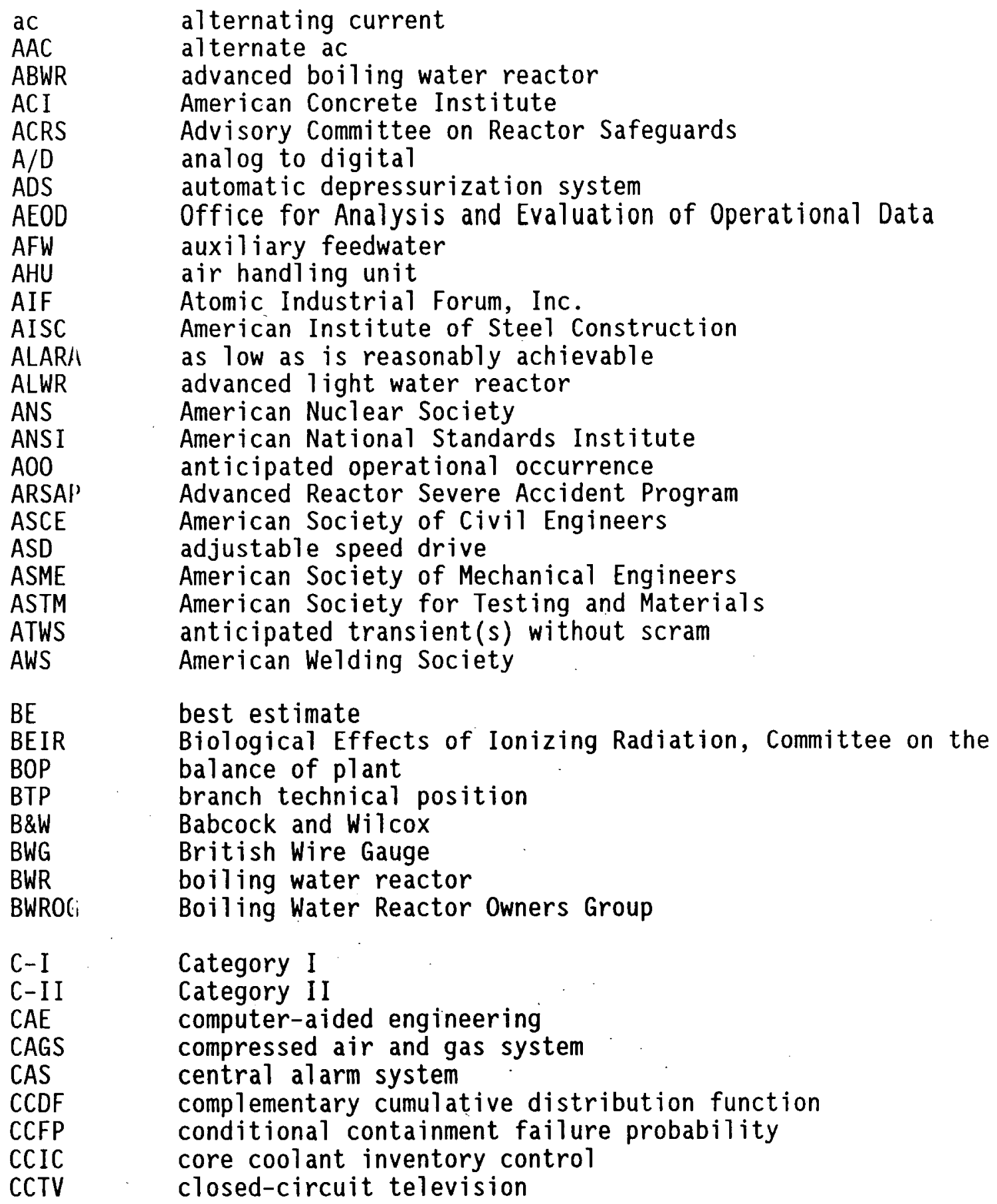




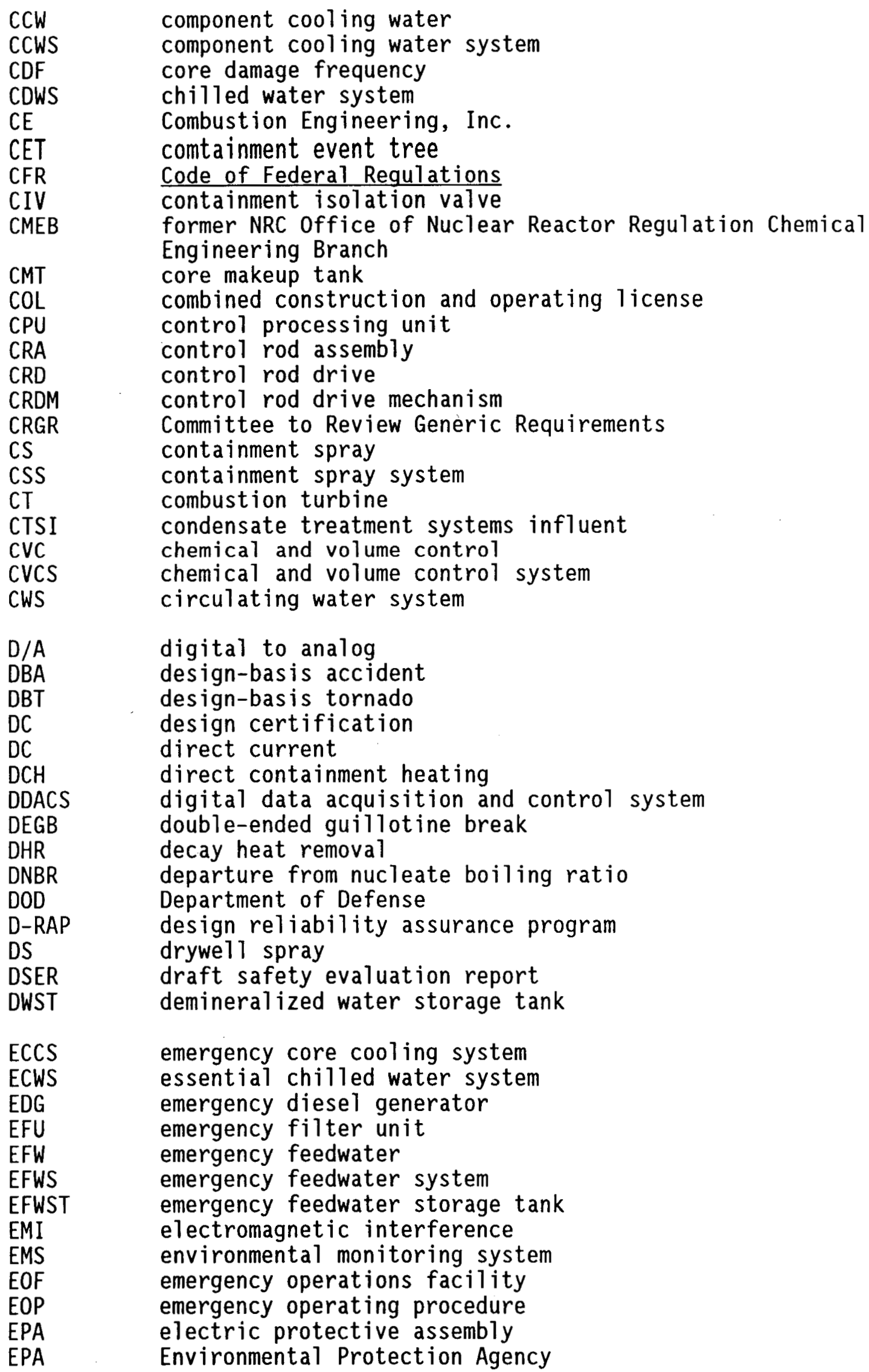




\begin{tabular}{|c|c|}
\hline $\begin{array}{l}\text { EPG } \\
\text { EPRI } \\
\text { ERF } \\
\text { ESF } \\
\text { ESFAS } \\
\text { ESI } \\
\text { ESW } \\
\text { ESWS }\end{array}$ & $\begin{array}{l}\text { emergency procedures guideline } \\
\text { Electric Power Research Institute } \\
\text { emergency response facility } \\
\text { engineered safety feature(s) } \\
\text { engineered safety feature actuation system } \\
\text { Energy Systems Group } \\
\text { essential service water } \\
\text { essential service water system }\end{array}$ \\
\hline $\begin{array}{l}\text { FDA } \\
\text { FIVE } \\
\text { FN } \\
\text { FPCCS } \\
\text { FPLC } \\
\text { FPLCS } \\
\text { FPS } \\
\text { FSER }\end{array}$ & $\begin{array}{l}\text { final design approval } \\
\text { fire vunerability evaluation } \\
\text { ferrite number } \\
\text { fuel pool cooling and cleanup system } \\
\text { fission product leakage control } \\
\text { fission product leakage control system } \\
\text { fire protection system } \\
\text { final safety evaluation report }\end{array}$ \\
\hline $\begin{array}{l}\text { GDC } \\
\text { GE } \\
\text { GI } \\
\text { GIMCS } \\
\text { GIP } \\
\text { GL } \\
\text { GPM } \\
\text { GRWPS } \\
\text { GSI }\end{array}$ & $\begin{array}{l}\text { general design criterion(a) } \\
\text { General Electric Company } \\
\text { generic issue } \\
\text { generic issues management control system } \\
\text { Generic Implementation Procedure } \\
\text { generic letter } \\
\text { gallon(s) per minute } \\
\text { gaseous radioactive waste processing system } \\
\text { generic safety issue }\end{array}$ \\
\hline $\begin{array}{l}\text { HCLPF } \\
\text { HEPA } \\
\text { HF } \\
\text { HPC I } \\
\text { HPI } \\
\text { HRA } \\
\text { HVAC } \\
\text { HWC }\end{array}$ & $\begin{array}{l}\text { high confidence/low probability of failure } \\
\text { high-efficiency particulate air } \\
\text { human factors } \\
\text { high-pressure coolant injection } \\
\text { high-pressure injection } \\
\text { human reliability analysis } \\
\text { heating, ventilating, and air conditioning } \\
\text { hydrogen water chemistry }\end{array}$ \\
\hline $\begin{array}{l}\text { IASCC } \\
\text { I\&C } \\
\text { ICC } \\
\text { ICS } \\
\text { ICST } \\
\text { IDCOR } \\
\text { IE } \\
\text { I\&E } \\
\text { IEB } \\
\text { IEC } \\
\text { IEEE } \\
\text { IES } \\
\text { IGA } \\
\text { IGSCC } \\
\text { IIT } \\
\text { ILRT } \\
\text { IMS }\end{array}$ & $\begin{array}{l}\text { irradiation-assisted stress corrosion cracking } \\
\text { instrumentation and controls } \\
\text { inadequate core cooling. } \\
\text { integrated control system } \\
\text { influent to condensate storage tank } \\
\text { Industry Degraded Core Rulemaking } \\
\text { office of Inspection and Enforcement } \\
\text { office of Inspection and Enforcement } \\
\text { office of Inspection and Enforcement bulletin } \\
\text { International Electrotechnical Commission } \\
\text { Institute of Electrical and Electronics Engineers } \\
\text { Illumination Engineering Society } \\
\text { intergranular attack } \\
\text { intergranular stress corrosion cracking } \\
\text { incident investigation team } \\
\text { integrated leak rate test } \\
\text { information management system }\end{array}$ \\
\hline
\end{tabular}




\begin{tabular}{|c|c|}
\hline IN & NRC information notice \\
\hline INPO & Institute of Nuclear Power Operations \\
\hline IPCEA & Insulated Power Cable Engineers Association \\
\hline & individual plant evaluation \\
\hline IRWST & in-containment refueling water storage tank \\
\hline ISI & inservice inspection \\
\hline ISLOCA & intersystem loss-of-coolant accident \\
\hline IST & inservice testing \\
\hline ITAAC & inspections, tests, analyses, and acceptance criteria \\
\hline LBB & leak before break \\
\hline LBHS & large-bore hydraulic snubber \\
\hline LCO & limiting condition(s) for operation \\
\hline LCS & leakage control system \\
\hline LCS & local control station \\
\hline LDB & licensing design basis \\
\hline LDR & load definition report. \\
\hline LLNL & Lawrence Livermore National Laboratory \\
\hline LOCA & loss-of-coolant accident \\
\hline LOFT & loss-of-fluid test \\
\hline LOOP & loss of offsite power \\
\hline LRB & iicensing review basis \\
\hline LRFD & load and resistance factor design \\
\hline LRWPS & liquid radioactive waste processing system \\
\hline LTOP & low-temperature overpressure protection \\
\hline LWR & light water reactor \\
\hline MAAP & modular accident analysis program \\
\hline MCC & motor control center \\
\hline MCPR & minimum critical power ratio \\
\hline MCR & main control room \\
\hline MF & moderate frequency \\
\hline MFW & main feedwater \\
\hline M-MI & man-machine interface \\
\hline M-MIS & man-machine interface system(s) \\
\hline MOV & motor-operator valve \\
\hline MPA & multiplant action \\
\hline MSIV & main steam isolation valve \\
\hline MSIVLCS & main steam isolation valve leakage control system \\
\hline MTC & moderator temperature coefficient \\
\hline MWD/MTU & megawatt-day(s) per metric ton of uranium \\
\hline MWSE & makeup water systems effluent \\
\hline MWSG & makeup water to steam generator \\
\hline MWST & makeup water storage tank \\
\hline NCC 、 & natural convection cooldown \\
\hline NCIG & Nuclear Construction Issues Group \\
\hline NDE & nondestructive examination \\
\hline NDT & nil ductility temperature \\
\hline NECWS & nonessential chilled water system \\
\hline NESWS & noneseential service water system \\
\hline NFPA & National Fire Protection Association \\
\hline NNS & Non-nuclear safety \\
\hline
\end{tabular}




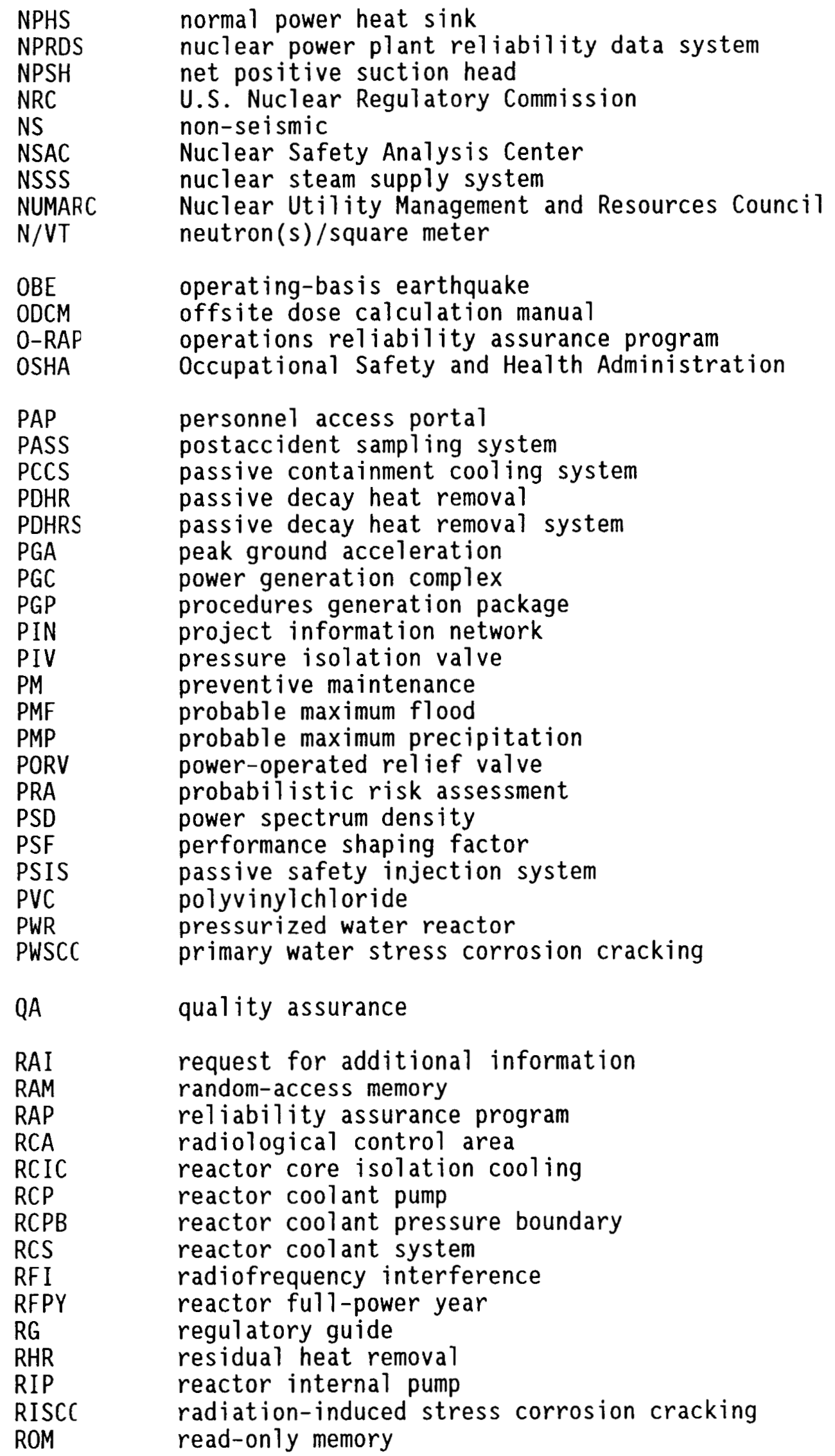




\begin{tabular}{|c|c|}
\hline RPS & reactor protection system \\
\hline RPV & reactor pressure vessel \\
\hline RSDC & reactor shutdown cooling \\
\hline RTB & reactor trip breaker \\
\hline RTD & resistance temperature detector \\
\hline $\mathrm{RT}_{\mathrm{NDT}}$ & nil ductility temperature \\
\hline RTS & reactor trip system \\
\hline RV & reactor vessel \\
\hline RVLIS & reactor vessel level instrumentation system \\
\hline RWCS & reactor water cleanup system \\
\hline RWCU & reactor water cleanup \\
\hline SAFDL & specified acceptable fuel design limit \\
\hline SAR & safety analysis report \\
\hline SAS & secondary alarm station \\
\hline SBWR & simplified boiling water reactor \\
\hline SCA & sneak circuit analysis \\
\hline $\mathrm{SCC}$ & stress corrosion cracking \\
\hline SDV & safety depressurization and vent \\
\hline SDV & scram discharge volume \\
\hline SDVS & safety depressurization and vent system \\
\hline SECY & NRC office of the Secretary (of the Commission) \\
\hline SEP & Systematic Evaluation Program \\
\hline SER & safety evaluation report \\
\hline SFA & single-failure analysis \\
\hline SFC & single-failure criterion \\
\hline SG & steam generator \\
\hline SGI & safeguards information \\
\hline SGOF & steam generator overfill \\
\hline SGTR & steam generator tube rupture \\
\hline SGTS & safety gas treatment system \\
\hline SHARP & systematic human action reliability procedure \\
\hline SI & safety injection \\
\hline SIS & safety injection system \\
\hline SLC & standby liquid control \\
\hline SLCS & standby liquid control system \\
\hline SMB & safety margin basis \\
\hline SOER & significant operating event report \\
\hline SPDS & safety parameter display system \\
\hline SQAP & Sofware Quality Assurance Program \\
\hline SQUG & Seismic Qualification Utilities Group \\
\hline SRM & staff requirements memorandum(a) \\
\hline SROA & safety-related operator action \\
\hline SRP & Standard Review Plan (NUREG-0800) \\
\hline SRV & safety/relief valve \\
\hline SSAR & standard safety analysis report \\
\hline SSC & structures, systems, and components \\
\hline SSE & safe shutdown earthquake \\
\hline SSI & soil-structure interaction \\
\hline SSW & safety service water \\
\hline STCP & Source Term Code Package \\
\hline SWAP & Service Water Assistance Program \\
\hline SWS & service water system \\
\hline
\end{tabular}




$\begin{array}{ll}\text { TBCCWS } & \text { turbine building component cooling water system } \\ \text { TDI } & \text { Transamerica Delaval, Inc. } \\ \text { THERP } & \text { technique for human error rate prediction } \\ \text { TID } & \text { technical information document } \\ \text { TIP } & \text { traversing in-core probe } \\ \text { TMI } & \text { Three Mile Island } \\ \text { TMI-2 } & \text { Three Mile Island Unit 2 } \\ \text { TS } & \text { technical specification(s) } \\ \text { TSC } & \text { technical support center } \\ \text { UBC } & \text { Uniform Building Code } \\ \text { UHS } & \text { ultimate heat sink } \\ \text { UPS } & \text { uninterruptible power supply } \\ \text { URS } & \text { ultimate rupture strength } \\ \text { USI } & \text { unresolved safety issue } \\ \text { UT } & \text { ultrasonic test } \\ \text { UV } & \text { undervoltage } \\ & \text { volt } \\ \text { V } & \text { verification and validation } \\ \text { V\&V } & \\ \text { WS } & \text { wetwell spray }\end{array}$




\section{APPENDIX D}

\section{PRINCIPAL CONTRIBUTORS}

\section{NRC Personnel}

H. Asliar

R. Borchardt

B. Bordinick

J. Brammer

K. Campe

C. Calpenter

R. Caruso

T. Chandrasekaran

T. Cheng

M. Chiramal

0 . Chopra

R. Correia

$R$. Dulse

R. Eclienrode

A. El--Bassioni

F. El:awila

T. Essig

E. Fo:r

J. Gallagher

R. Gallo

G. Gerrgiev

C. Goudman

J. Gu()

B. Hardin

C. Hinson

T. Hiltz

G. Hs i i

J. Joyce

F. Kaintor

G. Kelly

S. Kin

T. Kinn

L. Kopp

J. Kuilrick

J. Lazevnick

E. Le?

J. Le?

S. Le'?

A. Lerin

J. Le'/ine

C. Li

Y. C. Li

J. Lyions

M. Ma'l Toy

J. Martin
Review Area

structural engineering

project management

legal counsel

mechanical engineering

probablistic risk assessment

reliability assurance

systems

plant systems

structural engineering

instrumentation and controls

electrical systems

human factors, reliability assurance

physical security

human factors

probablistic risk assessment

research (plant systems)

radiation protection

emergency planning

instrumentation and controls

operator 1 icensing

materials engineering

human factors

plant systems

research

radiation protection

project management

reactor systems

instrumentation and controls

emergency planning

probablistic risk assessment

structural engineering

project management

reactor systems

plant systems

electrical systems

mechanical engineeering

radiation protection

structural engineering

reactor systems

meteorology

plant systems

mechanical engineering

plant systems

project management

radiation protection 
E. McKenna

B. Mendelsohn

J. Monninger

J. Moore

D. Notley

R. Palla

K. Parczewski

L. Phillips

R. Pichumani

T. Pohida

T. Polich

F. Rinaldi

R. Rothman

M. Rubin

G. Schwenk

J. Sharkey

P. Shea

L. Shotkin

B. Siegel

F. Skopec

D. Smith

P. Sobel

L. Soffer

I. Spickler

J. Spraul

J. Stewart

D. Terao

D. Thatcher

G. Thomas

C. Tinkler

J. Tsao

M. Waterman

J. Wigginton

F. Witt

R. Woods

$P$. Worthington quality assurance

physical security

plant systems

legal counse?

plant systems

probablistic risk assessment

chemical engineering

reactor systems

structural engineering

instrumentation and controls

reliability assurance

structural engineering

geosciences

reactor systems

reactor systems

reliability assurance

licensing assistance

research ( $p l a n t$ systems)

project management

radiation protection

human factors

geosciences

research (source term)

radiation protection

quality assurance

instrumentation and controls

mechanical engineering

electrical systems

reactor systems

research

material engineering

instrumentation and controls

radiation protection

chemical engineering

research (generic safety issues)

research (plant systems) 


\section{APPENDIX E \\ COMMISSION PAPERS APPLICABLE \\ TO ADVANCED LIGHT WATER REACTORS}

SECY-77-439, "Single Failure Criterion," August 17, 1977.

SECY-136-228, "Introduction of Realistic Source Term Estimates Into Licensing," August $6,1986$.

SECY-i38-147, "Integration Plan for Closure of Severe Accident Isues," May 25, 1988.

SECY-138-203, "Key Licensing Issues Associated With DOE-Sponsored Advanced Reactior Designs," July 15, 1988.

SECY-139-012, "Staff Plans for Accident Management Regulatory and Research Progrims," January 18, 1989.

SECY-i39-013, "Design Requirements Related to the Evolutionary Advanced Light Water Reactors (ALWRs)," January 19, 1989.

SECY-i39-153, "Severe Accident Design Features of the Advanced Boiling Water Reactır (ABWR), " May 10, 1989.

SECY-39-228, "Draft Safety Evaluation Report on Chapter 5 of the Advanced Light Water Reactor Requirements Document," July 28, 1989.

SECY-139-341, "Updated Light Water Reactor (LWR) Source Term Methodology and Poten:ial Regulatory Applications," November 6, 1989.

SECY-30-016, "Evolutionary Light Water Reactor (LWR) Certification Issues and Their Relationship to Current Regulatory Requirements," January 12, 1990.

SECY-90-241, "Level of Detail Required for Design Certification Under Part ! $2, "$ July $11,1990$.

SECY-!90-307, "Impacts of Source Term Timing on NRC Regulatory Positions," Augus:: 30, 1990.

SECY-190-313, "Status of Accident Management Programs and Plans for Implementation," September 5, 1990.

SECY-130-329, "Comparison of the General Electric Advanced Boiling Water Reactor (ABWR) Design and the Electric Power Research Institute's (EPRI's) Advanc:ed Light Water Reactor (ALWR) Requirements Document," September 20, 1990 .

SECY-90-341, "Staff Study on Source Term Update and Decoupling Siting from Design," October 4, 1990. 
SECY-90-353, "Licensing Review Basis for the Combustion Engineering, Inc., System 80+ Evolutionary Light Water Reactor, " October 12, 1990.

SECY-90-377, "Requirements for Design Certification Under 10 CFR Part 52," November 8, 1990.

SECY-90-406, "Quarterly Report on Emerging Technical Concerns," December 17, 1990.

SECY-91-074, "Prototype Decisions for Advanced Reactor Designs," March 19, 1991.

SECY-91-078, "Chapter 11 of the Electric Power Research Institute's (EPRI's) Requirements Document and Additional Evolutionary Light Water Reactor (LWR) Certification Issues," March 25, 1991.

SECY-91-135, "Conclusions of the Probabilistic Seismic Hazard Studies Conducted for Nuclear Power Plants in the Eastern United States, "May 14, 1991 .

SECY-91-178, "Inspections, Tests, Analyses, and Acceptance Criteria (ITAAC) for Design Certifications and Combined Licenses," June 12, 1991.

SECY-91-210, "Inspections, Tests, Analyses, and Acceptance Criteria (ITAAC) Requirements for Design Review and Issuance of a Final Design Approval," July 16, 1991.

SECY-91-229, "Severe Accident Mitigation Design Alternatives for Certified Standard Designs," July 31, 1991.

SECY-91-262, "Resolution of Selected Technical and Severe Accident Issues for Evolutionary Light Water Reactor (LWR) Designs," August 16, 1991.

SECY-91-272, "Role of Personnel and Advanced Control Rooms in Future Nuclear Power Plants," August 27, 1991.

SECY-91-273, "Review of the Vendor's Test Programs To Support the Design Certification of Passive Light Water Reactors," August 27, 1991.

SECY-91-292, "Digital Computer Systems for Advanced Light Water Reactors," September 16, 1991 .

SECY-91-348, "Issuance of Final Revision to Appendix $J$ to 10 CFR 50, and Reslated Final Regulatory Guide 1.XXX (MS 021-5)," October 25, 1991.

SECY-92-030, "Integral System Testing Requirements for Westinghouse's AP600 Plant," January 27, 1992.

SECY-92-037, "Need for NRC-Sponsored Confirmatory Integral System Testing of the Westinghouse AP600 Design," January 31, 1992.

SECY-92-053, "Use of Design Acceptance Criteria During 10 CFR Part 52 Design Certification Reviews," February 19, 1992. 
SECY-12-092, "The Containment Performance Goal, External Events Sequences, and the Definition of Containment Failure for Advanced Light Water Reactors," March 17, 1992.

SECY-!12-120, "NRC Staff Reviews for the Westinghouse AP600 and the Genera7 Electric Simplified Boiling Water Reactor (SBWR) Designs," April 7, 1992.

SECY-92-127, "Revised Accident Source Terms for Light Water Nuclear Power Plant::," April 10, 1992.

SECY-92-133, "Draft Safety Evaluation Reports for Volume I and Volume III of the Electric Power Research Institute's Advanced Light Water Reactor Requilements Document," Apri1 14, 1992.

SECY-92-134, "NRC Construction Inspection Program for Evolutionary and Advanced Reactors Under 10 CFR Part 52," April 15, 1992.

SECY-92-170, "Rulemaking Procedures for Design Certification," May 8, 1992.

SECY-192-172, "Final Safety Evaluation Report for Volume II of the Electric Power Research Institute's Advanced Light Water Reactor Requirements Document, " May 12, 1992.

SECY-132-211, "NRC Confirmatory Integral System Testing for the General Electl-ic SBWR Design," June 5, 1992.

SECY-12-214, "Development of Inspections, Tests, Analyses, and Acceptance Criteria (ITAAC) for Design Certifications," June 11, 1992.

SECY-12-219, "NRC-Sponsored Confirmatory Testing of the Westinghouse AP600 Design," June 16, 1992. 


\section{APPENDIX $F$ \\ REPORT BY THE ADVISORY COMMITTEE ON REACTOR SAFEGUARDS}




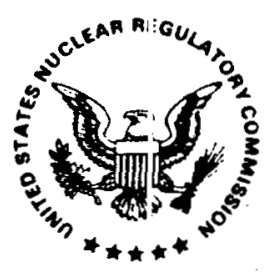

\author{
UNITED STATES \\ NUCLEAR REGULATORY COMMISSION \\ ADVISORY COMMITTEE ON REACTOR SAFEGUARDS \\ WASHINGTON, O. C. 20555
}

August 18, 1992

The Honorable Ivan Selin

Chisirman

U.is. Nuclear Regulatory Commission

Washington, D.C. 20555

Dear Chairman Selin:

SU3JECT: ELECTRIC POWER RESEARCH INSTITUTE ADVANCED LIGHT WATER REACTOR UTILITY REQUIREMENTS DOCUMENT -- VOLUME II, EVOLUTIONARY PLANTS

During the 387th and 388th meetings of the Advisory Committee on Rezctor Safeguards, July 9-11 and August 6-8, 1992, we reviewed the NR: staff's Final Safety Evaluation Report (FSER) for Volume II of the Electric Power Research Institute's (EPRI) Advanced Light water Reactor (ALWR) Utility Requirements Document (URD) for Evolutionary Plants. Our subcommittee on Improved Light water Reactors held meetings on June 17-18 and July 27, 1992, to review this subject. During these meetings, we had the benefit of discussions with representatives of the NRC staff and EPRI. We also had the benefit of the documents referenced.

In the early 1980s, EPRI established the ALWR program to support the United states utility industry efforts to ensure a viable nuclear power generation option for the $1990 \mathrm{~s}$ and beyond. The objective of the program was to ensure that future nuclear power plants would be safer, simpler, more robust with greater margins, more easily operated and maintained, and more certain of being constructed and licensed without delays. This was accomplished using utility experience, by establishing design philosophy, producing design criteria and guidance to achieve the objective, and addressing the policies and regulations of the NRC.

The EPRI ALWR URD is a compendium of technical requirements for design, construction, and performance of ALWR nuclear power plants for the 1990s and beyond. The URD consists of three volumes:

- Volume I, "ALWR Policy and Summary of Top-Tier Requirements," is a management-level synopsis of the URD, including the design objectives and philosophy, the overall physical configuration and features of a future nuclear plant design, and the steps necessary to take the proposed ALWR design criteria beyond the conceptual design state to a completed, functioning power plant. 
- Volume II, "ALWR Evolutionary Plant," consists of 13 chapters and contains utility design requirements for an evolutionary nuclear power plant (approximately 1350 Mwe).

- Volume III, "ALWR Passive Plant," contains utility design requirements for passive nuclear power plants (approximately 600 Mwe).

We have followed the development of the EPRI ALWR program from its inception and offered suggestions regarding safety improvements on several occasions. We also held numerous subcommittee and Committee meetings to consider and discuss the development of the EPRI URD program and the NRC staff's reviews.

The staff's review of the URD was conducted as described in NUREG1197. As noted therein, the staff used NUREG-0800, "Standard Review Plan (SRP) for the Review of Safety Analysis Reports for Nuclear Power Plants," for review guidance. In addition, the staff's review reflects the requirements of 10 CFR 52 , the Commission's policy statements on severe accidents, and the safety goals.

Although the SRP was used by the staff as guidance, the level of detail in the EPRI submittal did not permit a review of its completeness. (The SRP was written to support the review of safety analysis reports on specific plant designs for which a significant amount of design and construction information was available.) The staff conducted its review with the understanding that EPRI design criteria would meet all current regulations, except where deviations were identified. The staff's review of the URD focused primarily on determining whether the EPRI criteria did or did not conflict with current regulatory requirements.

In its review of Volume II of the URD, the staff identified a number of issues that will require additional information before the staff can reach a final conclusion. Initially, the staff divided the outstanding issues into three categories: (1) open policy issues on which the staff has proposed a position, but for which the commission has not yet provided guidance, (2) open issues that must be satisfactorily resolved before the staff can complete its review of the URD, or (3) confirmatory issues for which the staff will ensure follow up of commitments in the URD.

At this date the staff has identified 21 open policy issues that are included in a draft Commission paper, "Issues Pertaining to Evolutionary and Passive Light water Reactors and Their Relationship to Current Regulatory Requirements" that was issued on February 27, 1992. We provided our recommendations on the open policy issues pertaining to evolutionary plants in our letters which addressed SECY-90-016, SECY-91-078, and the draft SECY paper of February 7, 1992. 
The staff has handled the remaining 410 open issues which were identified in the FSER for Volume II by classifying them as "Vendor or Utility Specific Items" which must be satisfactorily addressed during the staff's review of a vendor- or utility-specific application. The staff plans to issue a supplement to the FSER after all evolutionary policy issues have reached final resolution. The staff indicated that they plan to interact with EPRI in an attempt to resolve significant open issues which may be resolved generically, and to include in a supplement any which are resolved.

We recommend generic resolution of as many of these issues as pcssible.

We commend EPRI for developing a comprehensive set of requirements. These will aid in the design of nuclear plants which will be safer, simpler, more robust, and more easily operated and maintained.

We commend the NRC staff for a very thorough review of the EPRI AIWR Evolutionary URD, and its work with EPRI to identify and $r \in s o l v e$ many issues relevant to licensing future LWRs. We recognize the NRC staff's position that its review necessarily is ir.complete.

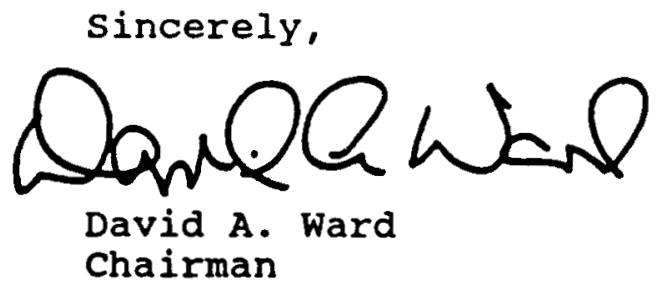

RE:ferences:

1. SECY-92-172, dated May 12, 1992, from James M. Taylor, Executive Director for operations, for the Commissioners, Subject: Final Safety Evaluation Report for Volume II of the Electric Power. Research Institute's Advanced Light water Reactor Requirements Document, including the following enclosures:

- Draft Safety Evaluation Report for Volume I, "Program Summary of the NRC Review of the Electric Power Research Institute's Advanced Light water Reactor Utility Requirements Document, " prepared by the office of Nuclear Reactor Regulation, U.S. Nuclear Regulatory Commission, dated May 1992

- Safety Evaluation Report for Volume II, "NRC Review of the Electric Power Research Institute's Advanced Light water Reactor Utility Requirements Document for Evolutionary Plant Designs," prepared by the office of Nuclear Reactor Regulation, U.S. Nuclear Regulatory Commission, dated May 1992 
August 18, 1992

2. Advanced Light Water Reactor Utility Requirements Document, Volume II, "ALWR Evolutionary Plant," Chapters 1-13, through Revision 4, dated April 1992, Prepared for Electric Power Research Institute 
(See instructions on the reverse)

\section{TITLE AND SUBTITLE}

NRC Review of Electric Power Research Institute's Advanced Light Water Reactor Utility Requirements Document

Program Summary

REPORT NUMBER

(Ausigned by NRC. Add Vol., Supp., Rev. and Addendum Numbers, if any.

NUREG-1242

Vol. 1

\section{name and mailing ac dress) \\ Associate Directorate for Advanced Reactors and License Renewal}

8. PERFORMING CRGANIZATION - NAME AND ADDRESS IIf NRC, provide Division, Office or Region, U.S. Nuclear Regulatory Commission, and mailing address; if contractor, provide

Office of Nuclear Reactor Regulation

U.S. Nuclear Regulatory Commission

Washington, D.C. 20555

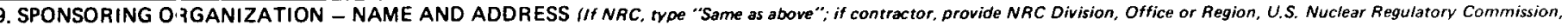
and mailing address.

Same as above.

\section{SUPPLEMENTA RY NOTES}

Project Number 669

11. ABSTRACT (20, words or less)

The staff of the U.S. Nuclear Regulatory Commission has prepared Volume 1 of a safety evaluation report (SER), "NRC Review of Electric Power Research Institute's Advanced Light Water Reactor Utility Requirements Document - Program Summary, " to document the results of its review of the Electric Power Research Institute's "Advanced Light Water Reactor Utility Requirements Document." This SER provides a discussion of the overall purpose and scope of the Requirements Document, the background of the staff's review, the review approach used by the staff, and a summary of the policy and technical issues raised by the staff during its review.

policy issues

optimization subjects

Utility Requirements Document (URD) Electric Power Research Institute (EPRI)

final design approval (FDA)

design certification (DC) combined operating license (COL)

evolutionary plants

standardization

regulatory stabilization

Advanced Reactor Service Accident Program (ARSAP)
1 icensability

10 CFR Part 52

passive plants

Utility Steering Committee
13. AVAILABILITY STATEMENT

Unlimited

14. SECURITY CLASSIFICATION

(This Page)

Unclassified

This Report)

Unclassified 